Uma abordagem de integração de dados de redes PPI e expressão gênica para priorizar genes relacionados a doenças complexas

Sérgio Nery Simões

\author{
TESE APRESENTADA \\ AO \\ Instituto de Matemática e Estatística \\ DA \\ Universidade de São Paulo \\ PARA \\ OBTENÇÃO DO TÍTULO \\ $\mathrm{DE}$ \\ DOUTOR EM CIÊNCIAS
}

\author{
Programa: Bioinformática \\ Orientador: Prof. Dr. Ronaldo Fumio Hashimoto \\ Coorientadora: Prof ${ }^{a}$. Dr ${ }^{\text {a }}$. Helena Brentani
}

Durante a elaboração deste trabalho, o autor recebeu auxílio financeiro do IFES e da CAPES

- São Paulo, 17 de março de 2015 - 



\title{
Uma abordagem de integração de dados de redes PPI e expressão gênica para priorizar genes relacionados a doenças complexas
}

\begin{abstract}
Esta versão da dissertação/tese contém as correções e alterações sugeridas pela Comissão Julgadora durante a defesa da versão original do trabalho, realizada em 30/06/2015. Uma cópia da versão original está disponível no Instituto de Matemática e Estatística da Universidade de São Paulo.
\end{abstract}

Comissão Julgadora:

- Prof. Dr. Ronaldo Fumio Hashimoto (orientador) - IME-USP

- Prof. Dr. Roberto Marcondes Cesar Junior - IME-USP

- Prof. Dr. Helder Takashi Imoto Nakaya - FCF-USP

- Prof. Dr. João Ricardo Sato - CMCC-UFABC - Externo

- Prof $^{\mathrm{a}}$. Dra ${ }^{\mathrm{a}}$. Mariana Maschietto - LNbio-CNPEM - Externo 



\section{Resumo}

SimõEs, S. N. Uma abordagem de integração de dados de redes PPI e expressão gênica para priorizar genes relacionados a doenças complexas. $105 \mathrm{f}$. Tese - Instituto de Matemática e Estatística, Universidade de São Paulo, São Paulo, 2015.

D OENÇAS COMPLEXAS são caracterizadas por serem poligênicas e multifatoriais, o que representa um desafio em relação à busca de genes relacionados a elas. Com o advento das tecnologias de sequenciamento em larga escala do genoma e das medições de expressão gênica (transcritoma), bem como o conhecimento de interações proteína-proteína, doenças complexas têm sido sistematicamente investigadas. Particularmente, baseando-se no paradigma Network Medicine, as redes de interação proteína-proteína (PPI - Protein-Protein Interaction) têm sido utilizadas para priorizar genes relacionados às doenças complexas segundo suas características topológicas. Entretanto, as redes PPI são afetadas pelo viés da literatura, em que as proteínas mais estudadas tendem a ter mais conexões, degradando a qualidade dos resultados. Adicionalmente, métodos que utilizam somente redes PPI fornecem apenas resultados estáticos e não-específicos, uma vez que as topologias destas redes não são específicas de uma determinada doença. Neste trabalho, desenvolvemos uma metodologia para priorizar genes e vias biológicas relacionados à uma dada doença complexa, através de uma abordagem integrativa de dados de redes PPI, transcritômica e genômica, visando aumentar a replicabilidade dos diferentes estudos e a descoberta de novos genes associados à doença. Após a integração das redes PPI com dados de expressão gênica, aplicamos as hipóteses da Network Medicine à rede resultante para conectar genes sementes (relacionados à doença, definidos a partir de estudos de associação) através de caminhos mínimos que possuam maior co-expressão entre seus genes. Dados de expressão em duas condições (controle e doença) são usados separadamente para obter duas redes, em que cada nó (gene) dessas redes é pontuado segundo fatores topológicos e de co-expressão. Baseado nesta pontuação, desenvolvemos dois escores de ranqueamento: um que prioriza genes com maior alteração entre suas pontuações em cada condição, e outro que privilegia genes com a maior soma destas pontuações. A aplicação do método a três estudos envolvendo dados de expressão de esquizofrenia recuperou com sucesso genes diferencialmente co-expressos em duas condições, e ao mesmo tempo evitou o viés da literatura. Além disso, houve uma melhoria substancial na replicação dos resultados pelo método aplicado aos três estudos, que por métodos convencionais não alcançavam replicabilidade satisfatória.

Palavras-chave: integração de dados, interação proteína-proteína, Network Medicine, doenças complexas, priorização gênica. 



\section{Abstract}

Simões, S. N. An integrative approach combining PPI networks and gene expression to prioritize genes related to complex diseases. $105 \mathrm{f}$. Ph. D. Thesis - Instituto de Matemática e Estatística, Universidade de São Paulo, São Paulo, 2015.

C OMPLEX DISEASES are characterized as being poligenic and multifactorial, so this poses a challenge regarding the search for genes related to them. With the advent of high-throughput technologies for genome sequencing and gene expression measurements (transcriptome), as well as the knowledge of protein-protein interactions, complex diseases have been sistematically investigated. Particularly, Protein-Protein Interaction (PPI) networks have been used to prioritize genes related to complex diseases according to its topological features. However, PPI networks are affected by ascertainment bias, in which the most studied proteins tend to have more connections, degrading the quality of the results. Additionally, methods using only PPI networks can provide just static and non-specific results, since the topologies of these networks are not specific of a given disease. In this work, we developed a methodology to prioritize genes and biological pathways related to a given complex disease, through an approach that integrates data from PPI networks, transcriptomics and genomics, aiming to increase replicability of different studies and to discover new genes associated to the disease. The methodology integrates PPI network and gene expression data, and then applies the Network Medicine Hypotheses to the resulting network in order to connect seed genes (obtained from association studies) through shortest paths possessing larger coexpression among their genes. Gene expression data in two conditions (control and disease) are used to obtain two networks, where each node (gene) in these networks is rated according to topological and coexpression aspects. Based on this rating, we developed two ranking scores: one that prioritizes genes with the largest alteration between their ratings in each condition, and another that favors genes with the greatest sum of these scores. The application of this method to three studies involving schizophrenia expression data successfully recovered differentially co-expressed gene in two conditions, while avoiding the ascertainment bias. Furthermore, when applied to the three studies, the method achieved a substantial improvement in replication of results, while other conventional methods did not reach a satisfactory replicability.

Keywords: data integration, protein-protein interaction, Network Medicine, complex diseases, gene prioritization. 



\section{Sumário}

$\begin{array}{ll}\text { Resumo } & \mathbf{v}\end{array}$

$\begin{array}{lc}\text { Abstract } & \text { vii }\end{array}$

$\begin{array}{lc}\text { Lista de Figuras } & \text { xiii }\end{array}$

$\begin{array}{ll}\text { Lista de Tabelas } & \text { xv }\end{array}$

1 Introdução 1

1.1 Considerações Preliminares . . . . . . . . . . . . . . . . . 1

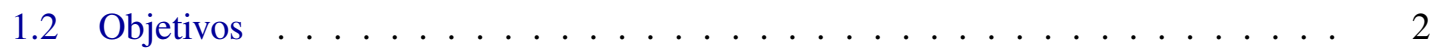

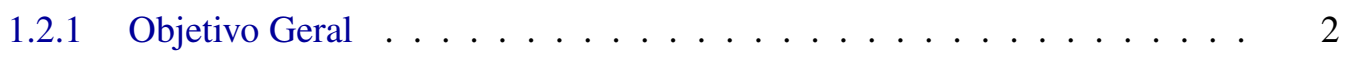

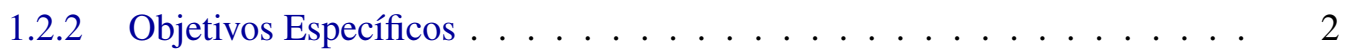

1.3 Contribuições ............................ . . . 3

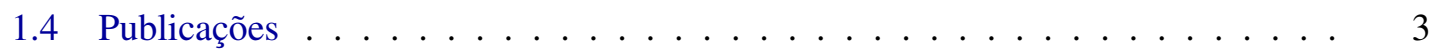

1.5 Organização do Texto . . . . . . . . . . . . . . . . . . . 4

2 Fundamentos Conceituais e Revisão $\quad 5$

2.1 Fundamentos Conceituais . . . . . . . . . . . . . . . . 5

2.1.1 Redes Biológicas como Grafos . . . . . . . . . . . . 5

2.1.2 Medidas de Centralidade em Redes Complexas . . . . . . . . . . . 6

2.1.3 Cálculo da Importância Relativa . . . . . . . . . . . . . . . . 8

2.1.4 Coeficiente de Concordância de Kendall . . . . . . . . . . . . . . 8

2.1.5 Métodos para Seleção de Genes . . . . . . . . . . . . . . . 9

2.2 Redes de Interação Proteína-Proteína . . . . . . . . . . . . . . . . . 10

2.2.1 Hipóteses Verificadas pela Network Medicine . . . . . . . . . . . 11

2.2.2 Aplicação das hipóteses de Network Medicine . . . . . . . . . . 12

2.2 .3 Viés da literatura ................... 16

3 Metodologia proposta $r$

3.1 Visão Geral . . . . . . . . . . . . . . . . . . . . . . . 19

3.2 Integração de Dados . . . . . . . . . . . . . . . . . . 21

3.2.1 Integração da Rede PPI com os Dados de Expressão . . . . . . . . . . 22

3.3 Cálculo da Importância Relativa . . . . . . . . . . . . . . . . . . . . . 23 
3.3.1 Seleção dos Caminhos Mínimos . . . . . . . . . . . . . . . . . . 23

3.3.2 Concordância de Kendall Modificado . . . . . . . . . . . . . . 26

3.3.3 Importância relativa dos genes em uma condição . . . . . . . . . . . . . 27

3.4 Seleção dos Genes . . . . . . . . . . . . . . . . . . . . . 28

3.4.1 Transformação similar ao método MAID . . . . . . . . . . . . . 28

4 Estudo de Caso

4.1 Materiais utilizados . . . . . . . . . . . . . . . . . . 32

4.1.1 Origem dos dados da Rede PPI . . . . . . . . . . . . 32

4.1.2 Origem dos Dados de Expressão . . . . . . . . . . . . . . . 32

4.1 .3 Conjunto de Genes Sementes . . . . . . . . . . . . . . . . . . . . . . . . . . . 33

4.1 .4 Materiais para Integração . . . . . . . . . . . . . . . . . . . . . 33

4.1.5 Ferramentas para análise dos genes selecionados . . . . . . . . . . 33

5 Resultados $\quad 35$

5.1 Análise Topológica da Rede PPI Integrada . . . . . . . . . . . . . . . . . . . . . . . . . . . . 35

5.2 Análise diferencial da rede PPI . . . . . . . . . . . . . . . . . . . 37

5.2.1 Configuração dos Parâmetros . . . . . . . . . . . . . . . . . . . . . 37

5.2.2 Estudo da Variação dos Parâmetros . . . . . . . . . . . . . . . . . 38

5.3 Comparação entre os métodos (DADA vs RWR vs $X$ vs $\Delta^{\prime}$ ) . . . . . . . . . . 42

5.3.1 Interseções e correlações entre os métodos (DADA, RWR, $X, \Delta^{\prime}$ ) . . . 44

5.3.2 Interseções e correlações do Grau vs (DADA, RWR, $X, \Delta^{\prime}$ ) . . . . . 45

5.4 Análise da Replicação dos Estudos ． . . . . . . . . . . . . . . . . . 47

5.4.1 Análise da Sobreposição entre os Resultados . . . . . . . . . . . . . . . 48

6 Análises Biológicas $\quad 53$

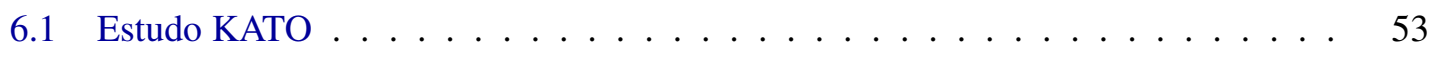

$6.1 .1 \quad$ Ranqueamento $\Delta^{\prime} \ldots \ldots \ldots \ldots \ldots \ldots$

6.1 .2 Ranqueamento $X \ldots \ldots \ldots \ldots \ldots \ldots$

6.1 .3 Discussão dos resultados . . . . . . . . . . . . . . . . . . . 58

6.1 .4 O Conjunto $(\mathrm{Grau} \cap X-\mathrm{Grau} \cap \mathrm{RWR}) \quad \ldots \ldots \ldots \ldots \ldots$

6.2 Interseção dos estudos KATO, ALTARC e BAHN . . . . . . . . . . . . . . 59

6.2 .1 Ranqueamento $\Delta^{\prime} \ldots \ldots \ldots \ldots$. . . . . . . . . . . . 59

6.3 Desempenho do Método . . . . . . . . . . . . . . . . . . . . 62

7 Conclusões

7.1 Resultados Alcançados . . . . . . . . . . . . . . . . . . . . . . 65

7.2 Trabalhos Futuros . . . . . . . . . . . . . . . . . . 66

$\begin{array}{ll}\text { A Categorias de processos biológicos } & 67\end{array}$

A.1 Ranqueamento $\Delta^{\prime} \ldots \ldots \ldots \ldots \ldots$. . . . . . . . . . . . . . . . . . . . . . . . . . 67

A.2 Ranqueamento $X \ldots \ldots \ldots \ldots \ldots \ldots$

A.3 Interseção dos estudos KATO, ALTARC e BAHN . . . . . . . . . . . . 68 
$\begin{array}{lll}\text { B Análises GO } & 71\end{array}$

$\begin{array}{lll}\text { C Análises KEGG } & 75\end{array}$

D Projeção de Neurônios - Análise de Componente Celular 79

$\begin{array}{ll}\text { Referências Bibliográficas } & 81\end{array}$ 



\section{Lista de Figuras}

3.1 Ilustração dos múltiplos caminhos mínimos entre duas proteínas da rede PPI . . . 20

3.2 Visão geral da metodologia. . . . . . . . . . . . . . . . . . . 21

3.3 Ilustração de um caminho da rede PPI após a integração com dados de expressão 22

3.4 Ilustração da seleção de um caminho mínimo utilizando dados de expressão em duas condições . . . . . . . . . . . . . . . . . . . . . . 24

3.5 Ilustração do problema do coeficiente de concordância de Kendall . . . . . . . . 27

3.6 Ilustração do efeito de decaimento . . . . . . . . . . . . . . . . . . . 28

5.1 Distribuição de pares de genes $X$ caminhos mínimos $\ldots \ldots \ldots \ldots$

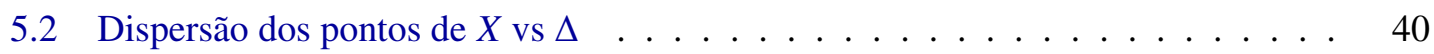

5.3 Detalhamento dos valores iniciais de $X \ldots \ldots \ldots \ldots$. . . . . . . . . . 42

5.4 A comparação entre 5\% de genes selecionados por $\Delta^{\prime}$ e DADA . . . . . . . . . . . . 43

5.5 Comparação entre os métodos (DADA vs RWR vs $X$ vs $\left.\Delta^{\prime}\right) \ldots \ldots \ldots \ldots$. . . . . 44

5.6 Comparação Grau vs (DADA, RWR, $\left.X, \Delta^{\prime}\right) \ldots \ldots \ldots \ldots \ldots$

5.7 Comparação das sobreposições entre os estudos . . . . . . . . . . . . . . . 48

5.8 Interseção dos $10 \%$ primeiros genes ranqueados por $\Delta^{\prime} \ldots \ldots \ldots$

5.9 Proporção média de ocorrência dos genes nos caminhos possíveis . . . . . . . . 51

5.10 Interseção dos $10 \%$ primeiros genes ranqueados por $X$ em cada estudo . . . . . . 52

6.1 Vias hiper-representadas (ranqueamento $\Delta^{\prime}$ e estudo KATO) . . . . . . . . . . 54

6.2 Vias hiper-representadas (ranqueamento $X$ e estudo KATO) . . . . . . . . . . . 56

6.3 Módulos PPI humanos hiper-representados nos 129 genes. . . . . . . . . . . . . 61

6.4 Funções relacionadas aos módulos PPI humanos hiper-representados . . . . . . . 61

6.5 Módulo 26 com 14 genes hiper-representados . . . . . . . . . . . . . . . . 62

A.1 Distribuição dos genes nos processos biológicos (ranqueamento $\Delta^{\prime}$ e estudo KATO) 67

A.2 Distribuição dos genes nos processos biológicos (ranqueamento $X$ e estudo KATO) 68

A.3 Distribuição dos 129 genes nos processos biológicos . . . . . . . . . . . . . . 69

B.1 Categorias dos processos biológicos (ranqueamento $\Delta^{\prime}$ e estudo KATO) . . . . 72

B.2 Categorias dos processos biológicos (ranqueamento $X$ e estudo KATO) . . . . . . 73

B.3 Categorias dos processos biológicos (ranqueamento $\Delta^{\prime}$, interseção dos 3 estudos) 74

C.1 KEGG - via de sinalização ErbB . . . . . . . . . . . . . . . . . . . . . 76 
C.2 KEGG - via de sinalização ErbB . 


\section{Lista de Tabelas}

3.1 Ilustração de caminhos mínimos e seus valores $W_{\max } \quad \ldots \ldots \ldots$. . . . . . 25

5.1 Lista de parâmetros utilizados. . . . . . . . . . . . . . . . . . . . . . 37

5.2 Valores médios e percentuais de caminhos selecionados por par de genes . . . . . 39

5.3 Algumas medidas (Mínimos, Máximos, Quartis, Percentis, Média e Desvio-Padrão) da distribuição de $X(\epsilon=0.05)$ para os estudos KATO, ALTAR e BAHN. . . . . 41

6.1 Doenças hiper-representadas $\left(\Delta^{\prime}-\mathrm{KATO}\right) \ldots \ldots \ldots \ldots \ldots$

6.2 Doenças hiper-representadas $(X-\mathrm{KATO}) \ldots \ldots \ldots \ldots$

D.1 Análise de enriquecimento da componente celular: projeções de neurônios . . . . 80 



\section{Agradecimentos}

Agradeço aos professores Ronaldo e Helena pela oportunidade de participar em seus projetos e por serem excelentes orientadores, sempre me ajudando a enxergar a direção certa e dedicando tempo para nos reunirmos. Ao grande amigo David Martins pelas inúmeras discussões e trocas de idéias proveitosas. A Patrícia por ser sempre muito prestativa e atenciosa. A todos colegas do laboratório de Bioinfo pelo companheirismo, em especial David Pires, Amanda, Talita, Jihan, Milton, Leandro, Michel, Jesús-Mena, Douglas, Fábio e Fabrício. A minha esposa por ser bastante compreensiva e companheira, e ao meu filho pelo seu sorriso inspirador, que me ajudou a retirar forças de onde eu não tinha pra continuar nos momentos mais difíceis. Aos meus pais pelo incentivo e ajuda e aos meus primos Márcio e Tati pela amizade e pelos benefícios. E a todos que, direta ou indiretamente me ajudaram nesse trabalho. Um grande obrigado!

Sérgio Nery Simões São Paulo, 17 de março de 2015. 



\section{Capítulo 1}

\section{Introdução}

Este capítulo apresenta uma breve introdução e motivação para o desenvolvimento deste trabalho, bem como os conceitos de doença complexa e os diversos fatores envolvidos em sua pesquisa, e também como as redes de interação proteína-proteína (PPI) estão sendo utilizadas em pesquisas envolvendo doenças complexas.

\subsection{Considerações Preliminares}

Doenças complexas são poligênicas e multifatoriais, ou seja, causadas por uma combinação de fatores genéticos e ambientais [Davey Smith et al., 2005]. Alguns exemplos de doenças complexas são Alzheimer, esquizofrenia, asma, doença de Parkinson, diabetes mellitus, esclerose múltipla, osteoporose, e muitas outras [Hunter, 2005]. Com relação aos fatores genéticos, doenças complexas são causadas por uma combinação de diferentes alterações genéticas em diversos genes, podendo levar a uma propagação anormal de sinais ao longo das vias biológicas. Nestas doenças, as perturbações genéticas podem desregular o mesmo módulo de um sistema celular, apesar de variar substancialmente em diferentes pacientes [Schadt, 2009].

É importante notar que vários estudos na literatura sobre genética de doenças complexas vem contribuindo para explicação de mecanismos fisiopatológicos, mas as listas de produtos finais resultantes desses estudos apresentam pouca convergência e baixa replicação. Desta forma, o estudo das vias compostas por vários genes ou combinações deles, tem se mostrado muito mais promissor que o estudo de genes individualmente como alvos terapêuticos, para compreender os mecanismos de doenças complexas e a identificação de potenciais alvos de drogas [Goh \& Choi, 2012]. Em particular, a utilização de redes PPI para priorização de genes candidatos em doenças complexas tem alcançado bons resultados [Cai et al., 2010; Chen et al., 2009; Goh \& Choi, 2012; Kaimal et al., 2011; Kohler et al., 2008; Vidal et al., 2011; Wu et al., 2008]. Com base em diversos desses trabalhos, Barabási et al. [2011] verificaram um conjunto de hipóteses na rede de interação proteína-proteína (PPI - Protein-Protein Interaction) chamadas de hipóteses da Network Medicine que eram usualmente adotadas de maneira implícita (ver Seção2.2.1).

Assumindo que genes previamente relacionados a uma doença e a determinadas vias biológicas tendem a ser coexpressos e colocalizados nas redes PPI, a integração de dados de diversos tipos de dados biológicos têm contribuído para a descoberta de novos genes e vias biológicas re- 
levantes para a compreensão da doença em questão. Neste trabalho, é proposta uma metodologia que integra dados de estudos de associação, expressão gênica e redes PPI para selecionar genes (e interações/ligações) que possam contribuir para explicar um fenótipo de doença comparado a controles. A rede PPI é obtida a partir de dados da literatura, e seus nós representam proteínas e suas arestas representam possíveis interações entre elas (ver Seção 2.2). É uma rede estática (pois seus estados não se alteram) e genérica (pois não existe uma rede PPI específica para cada doença).

Para tornar possível a diferenciação entre os estados (dos nós e interações) da rede - e assim produzir resultados mais específicos relacionados à doença em estudo - integramos dados de expressão (controle e doente) à rede PPI. Após essa integração, assumimos as hipóteses da Network Medicine e desenvolvemos um critério de pontuação para o cálculo da importância relativa dos genes pertencentes à vizinhança dos genes sementes (sabidamente associados a uma dada doença). Isto é realizado por conectar genes sementes aos genes de sua vizinhança através de caminhos na rede PPI, que são selecionados usando dados de expressão em duas condições - doença em estudo e controle. Em seguida, utilizamos as pontuações (escores) obtidas nessas duas condições para analisarmos diferencialmente os genes da sub-rede obtida, a fim de priorizá-los. Além dessa análise diferencial, o método também permite uma outra análise para verificar o quão central e coexpressos estão os genes obtidos em relação aos genes sementes.

Para validar o método, adotou-se esquizofrenia como estudo de caso e os dados de expressão gênica utilizados foram obtidos de Stanley Neuropathology Consortium Integrative Database (SNCID) ${ }^{1}$ [Kim \& Webster, 2010]. Foram utilizados 3 estudos do SNCID e cada estudo possui dados de expressão gênica de amostras de pacientes com esquizofrenia (doentes) e amostras de indivíduos não afetados (controles).

\subsection{Objetivos}

\subsubsection{Objetivo Geral}

O objetivo geral deste trabalho é priorizar genes e vias biológicas relacionados à uma dada doença complexa através de abordagens da biologia sistêmica (systems biology), integrando dados de redes de interação proteína-proteína, transcritômica e genômica visando aumentar a replicabilidade entre diferentes estudos.

\subsubsection{Objetivos Específicos}

- Integrar diferentes fontes de dados: variações genômicas (tal como: SNP’s - Single-nucleotide polymorphism) associadas à doença (mapeadas como genes sementes), redes de interação proteínaproteína e dados de expressão em duas condições: caso e controle.

- Estabelecer um critério que utilize as hipóteses da Network Medicine e de co-expressão gênica, para selecionar caminhos biologicamente relevantes na rede PPI que contenham os genes mais co-expressos aos genes sementes;

\footnotetext{
${ }^{1}$ (http://sncid.stanleyresearch.org)
} 
- Desenvolver um algoritmo (baseado em caminhos mínimos selecionados na rede PPI utilizando dados de expressão) para estimar as importâncias relativas dos genes (em relação aos genes sementes).

- Desenvolver um critério de pontuação (escore), que utilize as importâncias relativas extraídas (em duas condições), para priorização de genes (e interações) de maneira a refletir aspectos biológicos da doença complexa em estudo.

- Avaliar o método com dados de estudos de associação e de expressão da esquizofrenia, bem como comparar os resultados com outros métodos descritos na literatura.

\subsection{Contribuições}

As principais contribuições deste trabalho são as seguintes:

- Proposta de uma metodologia geral de integração de dados para encontrar genes candidatos relacionados à uma dada doença complexa;

- Melhoria na replicação dos resultados encontrados pelo método aplicado a 3 estudos diferentes de esquizofrenia (KATO, ALTARC e BAHN), alcançando uma replicabilidade de $46 \%$ para o escore $\Delta^{\prime}$ e de $70 \%$ para o escore $X$ (os escores $\Delta^{\prime}$ e o escore $X$ serão descritos no Capítulo 3 ). É importante mencionar que, por métodos convecionais (exemplo: diferenciação de expressão), tais estudos não alcançavam sobreposição entre as listas de genes resultantes;

- Proposta de um método (utilizando uma adaptação no coeficiente de concordância de Kendall) para selecionar caminhos mínimos entre dois genes na rede PPI que contenham genes mais coexpressos entre si, através da integração de dados de interatoma e de expressão gênica;

- Proposta da adaptação de um método (MAID) baseado em janela deslizante para selecionar os genes com as características mais diferencialmente alteradas entre as condições controle e doença.

\subsection{Publicações}

Além disso, durante o desenvolvimento deste trabalho obtivemos as seguintes publicações aceitas:

1. Resumo estendido aceito na conferência ACM-BCB 2012 (ACM Conference on Bioinformatics, Computational Biology and Biomedicine) para apresentação como poster [Simões et al., 2012], que ganhou o prêmio ACM-BCB'12 Best Poster Award.

2. Publicação de um artigo completo na conferência IEEE-BIBE 2014 (14th IEEE International Conference on Bioinformatics and Bioengineering), o qual explora a utilização do método Hitting Time aplicado a redes PPI para priorizar genes de TDAH (Transtorno do Déficit de Atenção e Hiperatividade) [Lima et al., 2014]. 
3. Publicação de um outro artigo completo na conferência IEEE-BIBE 2014 (14th IEEE International Conference on Bioinformatics and Bioengineering) em colaboração com pesquisadores do Indian Institute of Technology Kharagpur. Esse artigo integrou redes PPI com o método Multiview Clustering aplicado a dados de expressão gênica para identificar genes relacionados a leucemia e doença intersticial pulmonar [Swarnkar et al., 2014].

- O trabalho anterior foi convidado para ser estendido no periódico Springer NetMahib (Network Modeling Analysis in Health Informatics and Bioinformatics) ${ }^{1}$ e já está submetido.

4. Submissão recente de um artigo específico sobre o tema central da tese para o periódico BMC Bioinformatics. Este artigo foi aceito e está em processo de revisão.

\subsection{Organização do Texto}

No Capítulo 2, apresentamos uma revisão da literatura, alguns problemas em aberto e onde o nosso trabalho se insere. Também introduzimos alguns conceitos relativos às doenças complexas, ao uso de redes biológicas representadas como grafos, e às medidas de centralidade em redes complexas. No Capítulo 3, apresentamos as considerações realizadas para a integração de dados, as adaptações necessárias, o algoritmo para o cálculo da importância relativa e como foi desenvolvido o método para a seleção de genes. No Capítulo 4, identificamos os materiais e a doença utilizada como estudo de caso (esquizofrenia) neste trabalho. No Capítulo 5, apresentamos os resultados da aplicação do método e realizamos algumas considerações sobre aspectos relevantes do método proposto. No Capítulo 6, apresentamos as análises biológicas dos genes priorizados pelos méto$\operatorname{dos} \Delta^{\prime}$ e $X$ desenvolvidos, bem como suas sobreposições entre diferentes estudos. Verificamos que alguns genes e vias hiper-representados são descritos na literatura como associados à esquizofrenia. Finalmente, no Capítulo 7 discutimos os resultados obtidos, analisando as vantagens e desvantagens do método proposto, e discutindo possíveis desdobramentos futuros.

${ }^{1}$ http: //www . springer . com/new+\%26+forthcoming+titles+\%28default\%29/journal/13721 


\section{Capítulo 2}

\section{Fundamentos Conceituais e Revisão}

Devido aos diversos fatores envolvidos nas doenças complexas (genéticos e ambientais), a pesquisa nesta área constitui um verdadeiro desafio, especialmente as que envolvem buscas por genes relacionados a tais doenças. Para melhorar a identificação e priorização dos genes associados a doenças complexas, alguns trabalhos recentes introduziram o uso de bancos de dados de redes de interação proteína-proteína (ou redes PPI - Protein-Protein Interaction). Neste capítulo são apresentados alguns conceitos envolvendo o estudo de doenças complexas através da integração com dados de redes PPI, a modelagem de redes biológicas através de grafos e o uso de medidas de centralidade em redes complexas para auxiliar o entendimento das redes biológicas.

\subsection{Fundamentos Conceituais}

\subsubsection{Redes Biológicas como Grafos}

Em biologia sistêmica, existem algumas categorias de redes que usualmente compartilham características e propriedades. Pavlopoulos et al. [2011] apresentaram como esses diferentes tipos de redes biológicas podem ser modeladas usando teoria dos grafos. Entre essas categorias de redes biológicas, pode-se destacar: redes PPI (Protein-Protein Interaction), redes bioquímicas, redes de regulação transcricional, redes de transdução de sinal ou metabólicas.

Um grafo dirigido $G$ pode ser definido como um par $(V, E)$ em que $V$ é um conjunto de vértices representando os nós da rede e $E=\{(i, j) \mid i, j \in V\}$ é o conjunto de arestas representando as conexões entre os nós. Diz-se que dois vértices são vizinhos se possuírem uma conexão entre eles. Um grafo é dito não-dirigido se suas arestas não possuem informação de direcionalidade. Neste caso, suas arestas podem ser representadas por um par não ordenado, ou seja, a aresta $\{u, v\}$ é a mesma que $\{v, u\}$. Por outro lado, se as arestas de um grafo possuírem informação de direcionalidade, então o grafo é dito dirigido e suas arestas serão representadas por um par ordenado, ou seja, considera-se a aresta $(u, v)$ como tendo direção de $u$ para $v$, e consequentemente sendo diferente da aresta $(v, u)$. Em grafos não-dirigidos, o grau de um vértice é definido como o número de conexões (arestas) que esse vértice possui. Já em grafos dirigidos, faz-se a diferenciação de grau de entrada e grau de saída de acordo com a direção da aresta. Um grafo ponderado é definido como um grafo $G=(V, E)$ que possui uma função peso $w: E \rightarrow \mathbb{R}$ associada às arestas (em que $\mathbb{R}$ é o conjunto 
dos números reais).

Um passeio $p$ entre $v_{1} \in V$ e $v_{n} \in V$ é uma sequência específica de vértices $\left(v_{1}, v_{2}, \ldots, v_{n}\right)$ tal que $\left\{\left(v_{1}, v_{2}\right),\left(v_{2}, v_{3}\right), \ldots,\left(v_{n-1}, v_{n}\right)\right\} \subseteq E$. O comprimento de um passeio é seu número de arestas. Um caminho é um passeio que não possui vértices repetidos, ou seja, passa uma única vez por cada vértice. Num grafo com peso, a distância de um caminho é definida como a soma dos pesos de suas arestas e, num grafo sem peso, a distância é definida como a quantidade de arestas, ou seja, é como se cada aresta tivesse peso 1. Caminho mínimo [Dijkstra, 1959; Floyd, 1962] é definido como o caminho que possui a menor distância entre dois vértices.

\subsubsection{Medidas de Centralidade em Redes Complexas}

Alguns nós de uma rede podem apresentar propriedades topológicas que os destacam em relação aos demais. Por exemplo, é possível que um nó seja tão importante para a rede a ponto de desconectá-la, caso seja excluído. Nós capazes de afetar a topologia da rede dessa forma (ou de maneira semelhante) são chamados nós centrais. Em redes biológicas é importante identificar nós (centrais ou intermediários) que possam afetar a topologia da rede [Pavlopoulos et al., 2011]. Para que tais nós sejam detectados, existem algumas medidas de centralidade, e entre elas destacam-se: degree, betweenness, closeness, clustering, bridgeness, brokering. A seguir, são apresentadas as definições dessas medidas.

- degree: é o grau ou o número de arestas que um vértice (ou nó) possui. Para grafos dirigidos essa medida é caracterizada por grau de entrada e grau de saída. Vértices (ou nós) com graus muito altos são chamados de hubs [Barabási et al., 2011; Cho \& Zhang, 2010]. Assim como usualmente acontece em redes complexas de maneira geral, em redes biológicas, a remoção de um hub também pode causar um grande impacto na rede [Pavlopoulos et al., 2011].

Além disso, no contexto de redes biológicas há ainda duas classificações do conceito de hub: os Party hubs e date hubs [Agarwal et al., 2010; Han et al., 2004; Vidal et al., 2011]. Party hubs são nós altamente co-expressos com seus parceiros de interação, e parecem interagir com seus parceiros em todos os momentos ou condições testados. Date hubs parecem estar regulados mais dinamicamente em relação aos seus parceiros, interagindo com eles em diferentes momentos e/ou diferentes condições.

- betweenness: indica o quão intermediário é um vértice de seus vizinhos. Esta medida calcula a proporção de caminhos mínimos que passam por um dado nó em relação a todos os caminhos mínimos possíveis (entre os demais nós). Dado um grafo $G=(V, E)$, sejam $i, j$ e $v \in V$ vértices distintos, seja $\sigma_{i j}$ o número total de caminhos mínimos entre $i$ e $j$, e seja $\sigma_{i j}(v)$ o número de caminhos mínimos de $i$ a $j$ que passam por um vértice intermediário $v$. Então o betweenness pode ser calculado da seguinte forma [Barabási et al., 2011; Pavlopoulos et al., 2011]:

$$
\operatorname{Betweenness}(v)=\sum_{i \neq v \neq j \in V} \frac{\sigma_{i j}(v)}{\sigma_{i j}}
$$


- closeness: indica a proximidade que um nó está dos demais. É definida por:

$$
\text { Closeness }(i)=\frac{1}{\sum_{t \in V} \operatorname{dist}(i, t)}
$$

em que $V$ é o conjunto de vértices da rede e dist $(i, t)$ é a distância (tamanho do caminho mínimo) entre os nós $i$ e $t$.

- clustering: pode ser entendido de certa maneira como o número de conexões entre os vizinhos de um dado vértice [Hwang et al., 2006]. O coeficiente de clustering pode ser definido como:

$$
\text { Clustering }(i)=\frac{2 n}{k_{i}\left(k_{i}-1\right)}
$$

em que $n$ denota o número de ligações diretas que conectam os $k_{i}$ vizinhos mais próximos do nó $i$. Varia de zero (para um nó que faz parte de um grupo fracamente conectado) a um (para um nó no centro de um grupo completamente conectado). Este coeficiente mede o grau de interconectividade na vizinhança de um nó.

- bridgeness: mede a extensão em que um nó ou aresta está localizado entre regiões conexas. Para um dado nó $i$, a medida de centralidade bridgeness é definida como o produto entre o betweenness e o coeficiente de bridge (BC) deste nó $i$ [Hwang et al., 2006]:

$$
\text { Bridgeness }(i)=\operatorname{Betweenness}(i) \times \operatorname{BC}(i)
$$

na qual o coeficiente de bridge é definido como:

$$
\mathrm{BC}(i)=\frac{\frac{1}{\operatorname{degree}(i)}}{\sum_{v \in N(i)} \frac{1}{\operatorname{degree}(v)}}
$$

no qual degree( $i$ ) é o grau do nó $i$ e $N(i)$ é o conjunto de vizinhos do nó $i$.

- brokering: Pode-se entender um gene broker como um hub que se conecta a muitos outros genes que não se conectam. Assim, o coeficiente de brokering para um dado nó $i$ pode ser calculado da seguinte forma:

$$
\text { Brokering }(i)=(1-\text { Clustering }(i)) * \operatorname{degree}(i)
$$

em que degree(i) é o grau do nó $i$.

Cai et al. [2010] observaram que alguns genes relacionados a doenças complexas (e mendelianas) tendem a ser altamente conectados, mas frequentemente estão conectados a genes vizinhos que não são bem conectados entre si, ou seja, aparentam desempenhar papéis de 'brokers' (corretores). Eles verificaram que esses genes apresentam simultaneamente graus anormalmente altos e coeficientes de clustering anormalmente baixos. Assim, relacionaram as medidas de grau e clustering e definiram o coeficiente de brokering. 


\subsubsection{Cálculo da Importância Relativa}

Importância relativa é um problema que consiste em determinar quais os nós são mais importantes em uma rede em relação a um conjunto de nós raízes previamente conhecidos como importantes. White \& Smyth [2003] propuseram diversas formas de computar a importância relativa de um nó em relação a um conjunto de nós raízes em redes gerais. Assim, dado um grafo $G(V, E)$ e um conjunto $R \in V$ de nós raízes (definidos como importantes), a importância relativa de um nó $t \in V$ em relação a tal conjunto $R$ é calculada pela Equação 2.7:

$$
I(t \mid R)=\frac{1}{|R|} \sum_{r \in R} I(t \mid r)
$$

onde $I(t \mid r)$ é a importância relativa individual do nó $t$ em relação ao nó individual $r \in R$. Eles avaliaram alguns algoritmos diferentes para o cálculo da importância relativa individual $I(t \mid r)$, dentre eles destacamos: caminhos mínimos, $k$ menores caminhos ponderados, cadeias de Markov, PageRank with Priors e HITS with Priors. Por exemplo, para caminhos mínimos ponderados, a importância relativa individual $I(t \mid r)$ descrita na Equação 2.7 pode ser calculada através da Equação 2.8 .

$$
I(t \mid r)=\sum_{i=1}^{\mathcal{P}(r, t)} \lambda^{-\left|p_{i}\right|}
$$

onde $\mathcal{P}(r, t)$ é um conjunto de caminhos entre $r$ e $t, p_{i}$ é o i-ésimo caminho em $\mathcal{P}$, e $\lambda$ e um coeficiente escalar ${ }^{1}, 1 \leq \lambda \leq \infty$, que determina quanta importância é conferida de $r$ para $t$. Nesta equação, a quantidade de importância que é conferida ao longo de um caminho decai exponencialmente com o comprimento do caminho. Além desta forma de calcular a importância relativa baseada em caminhos mínimos ponderados, eles utilizaram outras (tais como: $k$ menores caminhos ponderados, cadeias de Markov, PageRank with Priors e HITS with Priors, não mostradas aqui) e aplicaram-nas em redes de Internet, redes sociais, redes de colaboração, etc, e verificaram uma boa correlação entre os métodos.

\subsubsection{Coeficiente de Concordância de Kendall}

O coeficiente de concordância ${ }^{2}$ de Kendall $W$ [Kendall \& Smith, 1939] é uma medida da conformidade entre diversos $(m)$ juízes que estão avaliando um conjunto de $n$ objetos. Se os $n$ objetos forem ranqueados ${ }^{3}$ pelos $m$ juízes segundo algum critério, então esse coeficiente $W$ procura medir se há alguma evidência de concordância no julgamento entre esses $m$ indivíduos.

Suponha que haja um total de $n$ objetos e $m$ juízes e que cada objeto $i$ possua um posto $r_{i j}$ dado pelo juiz $j$. Neste caso, a soma dos postos dados ao objeto $i$ é:

$$
R_{i}=\sum_{j=1}^{m} r_{i j}
$$

Visto que os postos - atribuído por cada juiz - variam de 1 a $n$, então o valor médio das somas

\footnotetext{
${ }^{1}$ Os autores utilizaram esse coeficiente com valor $\lambda=2$.

${ }^{2}$ Este conceito será utilizado na Seção 3.3.2, para a definição do coeficiente de concordância de Kendall modificado.

${ }^{3}$ Os postos (ranks) variam de $1 \mathrm{a} n$.
} 
dos postos será:

$$
\bar{R}=\frac{m(n+1)}{2}
$$

Se definirmos $S$ como a soma observada dos quadrados dos desvios de soma dos postos $\left(R_{i}\right)$ em relação à média $(\bar{R})$ :

$$
S=\sum_{i=1}^{n}\left(R_{i}-\bar{R}\right)^{2}
$$

então, o coeficiente de concordância de Kendall $W$ será dado pela Equação 2.12:

$$
W=\frac{12 S}{m^{2}\left(n^{3}-n\right)}
$$

em que $m^{2}\left(n^{3}-n\right) / 12$ é o valor máximo possível de $S$ ocorrendo quando houver concordância máxima entre os juízes. Desta forma, o coeficiente de concordância de Kendall $W$ varia de 0 (nenhuma concordância) até 1 (concordância completa). Além disso, $W$ pode ser expresso em função da média $\left(\rho_{\mathrm{av}}\right)$ das $\left(\begin{array}{c}m \\ 2\end{array}\right)$ combinações de correlações de postos de Spearman:

$$
W=\frac{\rho_{\text {av }}(m-1)+1}{m}
$$

em que $\rho_{\text {av }}$ representa a média das correlações de postos de Spearman entre todos os pares de ranqueamentos sobre os quais está sendo calculada.

\subsubsection{Métodos para Seleção de Genes Diferencialmente Expressos}

Encontrar genes diferencialmente expressos é um problema muito importante em experimentos de microarranjos [Dudoit et al., 2002]. A princípio, pode-se calcular as diferenças de duas formas: absolutas ou relativas - e ambas apresentam problemas conforme descrito a seguir. Ao usar diferenças absolutas (ex: $\sigma_{D}-\sigma_{C}$ ), genes com escores muito altos tenderão a ter diferenças absolutas mais altas e com isso 'achatarão' as diferenças dos genes com escores menores, mesmo que estas sejam relevantes em termos relativos. Isto resultará em um viés que tenderá a priorizar genes com maiores escores. Por outro lado, se for utilizado algum tipo de diferença relativa (ex: $\sigma_{D} / \sigma_{C}$ ), juntamente com algum limiar de corte (cutoff ou fold) então haverá um viés para genes com menores escores, já que a diferença relativa dos menores escores tendem a variar mais que a diferença relativa dos escores maiores.

\section{Método MA-plot}

[Dudoit et al., 2002] descreveram diversos métodos estatísticos para identificação de genes diferencialmente expressos em experimentos de microarranjos de cDNA replicado. Ao final, sugeriram utilizar um método chamado MA-plot - explicado a seguir. Nos experimentos de microarray two-color são medidos dois valores $R$ e $G$, que representam respectivamente as intensidades vermelha e verde do experimento, que se referem a abundância de mRNA em duas condições diferentes (ex: caso e controle). O gráfico $M A$-plot plota a distribuição do logaritmo da razão das intensidades $\left(M=\log _{2}(R / G)\right)$ versus a média dos logaritmos das intensidades 
$\left(A=\frac{1}{2} \log _{2}(R G)=\frac{1}{2}\left(\log _{2} R+\log _{2} G\right)\right)$. O gráfico utiliza $A$ (como variável independente) no eixo das abscissas e $M$ (como variável dependente) no eixo das ordenadas.

\section{Método HT-Self}

Visando tratar problemas similares que ocorrem no MA-plot, Vêncio \& Koide [2005] propuseram um método que classifica genes como diferencialmente expressos usando técnicas de estimação não paramétricas (baseadas em um kernel de estimação de densidade) para gerar duas curvas de decisão próximas aos limites superiores e inferiores dos valores $M$ ao longo do domínio $A$. Esta técnica funciona bem para detectar genes diferencialmente expressos em experimentos de microarranjos, uma vez que a densidade de pontos (ao longo de todo o domínio A) costuma ser suficiente para aplicar o kernel de estimação de densidade. Entretanto, se este método HT-Self for aplicado a outros tipos de dados (que possuam regiões com baixa densidade de pontos), é possível que não haja pontos suficientes para a estimação de densidade em uma dada região. Neste caso, pode ser mais apropriado utilizar uma técnica paramétrica - com uma função pré-definida que melhor se ajuste ao contorno dos pontos dados.

\section{Método MAID}

Hecker et al. [2009] propuseram um método chamado MAID ${ }^{1}$ (MA-plot-based signal intensitydependent fold-change criterion) para selecionar genes com expressões alteradas usando como função paramétrica uma aproximação exponencial. Para filtrar os genes com expressões mais alteradas, o método MAID leva em consideração que a variabilidade nos logaritmos de razões (do inglês fold-changes) aumenta conforme a medida da intensidade do sinal diminui. Primeiro, o método MAID calcula os valores de $A$ e $M$ para cada gene. Em seguida, estima-se a variabilidade dependente da intensidade nos dados por computar o intervalo interquartil (IQR: interquartile range) dos valores de $M$ em uma janela deslizante. Posteriormente, uma função exponencial $f(x)=a e^{-b x}+c$ é ajustada - através de uma regressão não-linear robusta - aos valores de IQR obtidos pela janela deslizante. A função exponencial ajustada é usada para calcular os escores do método MAID, dividindo cada valor de $M$ por $f(A)$. Consequentemente, considera-se que quanto maior for o valor absoluto do escore MAID para um dado gene, mais alterado estará seu nível de expressão.

\subsection{Redes de Interação Proteína-Proteína}

Uma excelente revisão dos trabalhos envolvendo redes de Interação Proteína-Proteína (PPI Protein-Protein Interaction) foi realizada por Barabási et al. [2011], denominada por Network Medicine. Trata-se de uma abordagem de redes aplicadas a doenças humanas. Segundo eles, as ferramentas emergentes da Network Medicine oferecem uma plataforma para explorar sistematicamente, não somente a complexidade molecular de uma doença particular, levando a identificação de módulos e vias, mas também os relacionamentos moleculares entre os fenótipos de doença aparentemente distintos. Eles verificaram a hipótese chave de que um fenótipo de doença é raramente

\footnotetext{
${ }^{1}$ Este conceito será utilizado na Seção 3.4.1, para embasar a definição do escore de alteração $\Delta$.
} 
uma consequência de uma anormalidade do produto de um único gene, mas reflete vários processos biológicos que interagem em uma rede complexa. Desta forma, justificaram que abordagens baseadas em redes para doenças humanas possuem múltiplos potenciais para estudos biológicos e aplicações clínicas, ou seja, podem contribuir para a busca de biomarcadores de diagnóstico, prognóstico e resposta a tratamentos. Além disso, tais estudos também podem nos ajudar a compreender comorbidades, pois Goh et al. [2007] também encontraram resultados que sugerem que a origem da maioria das doenças genéticas são compartilhadas com outras doenças.

Redes PPI podem ser representadas por grafos e, desta forma, é possível usar diversos conceitos de teoria dos grafos e de redes complexas para extrair informações topológicas (ex: medidas de centralidade) de tais redes que possam auxiliar nas análises biológicas. Além disso, novos con$\operatorname{ceitos}^{1}$ (ex: brokers, party hubs, date hubs, etc) foram criados para refletir algumas características biológicas a fim de identificar nós da rede que sejam mais relevantes biologicamente. A seguir, são apresentados alguns destes conceitos e como eles podem ser utilizados em redes biológicas representadas por grafos.

\subsubsection{Hipóteses Verificadas pela Network Medicine}

Barabási et al. [2011] investigaram o relacionamento entre os genes essenciais ${ }^{2}$, os hubs e os genes que causam doença em humanos bem como sua localização no interatoma ${ }^{3}$. Eles verificaram que de um total de 25 mil genes humanos, 1665 genes são essenciais e 1777 são genes relacionados à doença, e estes dois conjuntos de genes possuem uma interseção (overlap) de apenas 398 genes que são essenciais e genes de doença. Portanto, a maioria dos genes que causam doença são genes não essenciais - já que problemas em genes essenciais podem causar letalidade embrionária.

Goh et al. [2007] constataram que genes não essenciais relacionados à doença não possuem tendência de serem hubs e tendem a se expressar em tecidos específicos, localizados na periferia do interatoma. Entretanto, genes essenciais que não estão associados à doença tendem a estarem associados a hubs e se expressarem em múltiplos tecidos. Tais genes tendem a ser relativamente centrais no interatoma. Em resumo, não são os genes de doença, mas sim os genes essenciais que codificam as proteínas que são os principais hubs na rede PPI humana.

Barrenas et al. [2009] verificaram que genes de doenças complexas são menos centrais no interatoma humano que genes essenciais e de doenças monogênicas. Eles também observaram que doenças pertencentes à mesma classe nem sempre apresentam tendência em compartilhar genes comuns de doença. Tais fatores podem dificultar bastante a replicabilidade em diferentes estudos. Assim, a falta de replicabilidade de tais estudos tem mostrado que parece ser muito mais importante buscar conjuntos de genes e vias comumente alterados do que tentar achar a mesma alteração em um conjunto de diferentes casos.

Partindo dessa perspectiva de redes, naturalmente é respondida uma importante questão sobre a localidade dos genes relacionados à doença - que foi investigada por Barabási et al. [2011]: 'estariam os genes localizados de forma aleatória no interatoma, ou existem correlações detectá-

\footnotetext{
${ }^{1}$ Esses conceitos foram apresentados na Subseção 2.1.1.

${ }^{2}$ Genes essenciais são aqueles em que sua ausência está associada com letalidade embrionária.

${ }^{3}$ Interatoma é todo o conjunto de interações moleculares (ex: entre moléculas de proteínas, lipídios, carboidratos, etc) em uma dada célula, mas este termo é comumente usado para se referir mais especificamente a redes PPI.
} 
veis entre sua localização e sua topologia na rede?' Para responder esta pergunta, eles levantaram algumas hipóteses que foram verificadas e denominadas de hipóteses da Network Medicine:

- Hubs

Genes essenciais in utero tendem a estar no centro funcional (codificando proteínas hubs e se expressando em múltiplos tecidos) do interatoma. Por outro lado, genes não essenciais de doença (representando a maioria dos genes de doença conhecidos) segregam na periferia funcional do interatoma (geralmente não sendo os hubs mais centrais da rede).

\section{- Hipótese da Localidade}

Proteínas envolvidas com a mesma doença possuem tendência aumentada de interagirem umas com as outras.

- Corolário da Hipótese da Localidade

Mutações em proteínas que interagem entre si frequentemente levam a fenótipos de doenças similares.

\section{- Hipótese de Módulo de Doença}

Componentes celulares associados a um fenótipo específico de doença apresentam uma tendência de agruparem-se na mesma vizinhança da rede.

\section{- Princípio da Parcimônia da Rede}

Vias moleculares causais frequentemente coincidem com os caminhos mínimos moleculares entre os componentes sabidamente associados à doença.

\section{- Hipótese dos componentes compartilhados}

Doenças que compartilham componentes celulares (genes, proteínas, microRNAs e metabólitos) associados a doenças apresentam similaridades fenotípicas e comorbidade.

É importante mencionar que a hipótese hubs verificada por Barabási et al. [2011] diz que genes não essenciais envolvidos com a doença geralmente não são os genes mais centrais (essenciais) da rede como um todo. Porém, isto não quer dizer que tais genes de doença não possam ter alto grau (hubs locais) na periferia do interatoma. Por exemplo, Cai et al. [2010] descobriram que existe um tipo de hub - denominado broker - que possui tendência a estar envolvido com doenças complexas (e mendelianas). Brokers são nós que possuem ao mesmo tempo um alto grau (degree) e um baixo coeficiente de clustering (i.e. conexões entre os seus vizinhos são praticamente ausentes) conforme definição de brokering apresentada na Seção 2.1.2.

\subsubsection{Aplicação das hipóteses de Network Medicine}

Conforme já mencionado, a priorização dos genes relevantes associados às doenças complexas é um desafio significativo, pois essas doenças são poligênicas e multifatoriais. Assim, pacientes com a mesma doença complexa podem apresentar diferentes perturbações genéticas [Schadt, 2009]. Com o advento das tecnologias de sequenciamento do genoma em larga escala, medições de expressão gênica (transcriptoma), e mapeamento de interações proteína-proteína, doenças complexas têm sido sistematicamente investigadas. 
Diversos trabalhos descritos na literatura utilizaram algumas hipóteses da Network Medicine (e.g. localidade, módulo de doença ou o princípio da parcimônia da rede) para analisar redes PPI ou para inferir vias biológicas e/ou sub-redes entre grupos de genes de origem e alvo relacionados à doença [Aittokallio \& Schwikowski, 2006; Chuang \& Roth, 2001; Managbanag et al., 2008; Missiuro et al., 2009; Przulj et al., 2004; Sun et al., 2010] .

O estudo de associação em escala genômica (GWAS - genome-wide association study) é uma abordagem que tem melhorado a compreensão da base genética de muitas características complexas [McCarthy et al., 2008]. No entanto, ele falha em revelar a maioria das variantes genéticas que possuem efeitos relativamente pequenos [Solovieff et al., 2013; Wang et al., 2010]. A análise de transcritoma geralmente utiliza correlações calculadas em perfis de expressão gênica para inferir se há co-expressão entre dois genes [Stuart et al., 2003]. Baseando-se nesse princípio, algumas aplicações de bioinformática começaram análises de redes de co-expressão gênica ponderada que é um método de biologia sistêmica para descrever os padrões de correlação entre genes através amostras de microarranjos.

Para auxiliar em análises de redes de co-expressão gênica, Langfelder \& Horvath [2008] desenvolveram um pacote na linguagem R chamado WGCNA (Weighted correlation network analysis - análises de rede de correlação ponderada). Este pode ser utilizado para: (i) encontrar (clusters) módulos de genes altamente correlacionados; (ii) sumarizar os perfis dos nós de um dado módulo por um nó hub representativo; (iii) identificar módulos semelhantes; (iv) anotar os nós da rede informando quão próximos eles estão dos módulos identificados; (v) definir a vizinhança da rede de dado conjunto de nós sementes; (vi) examinar nós baseados em algum critério, tal como propriedades topológicas da rede; (vii) contrastar redes em condições diferentes, realizando a análise diferencial da rede.

Ideker \& Krogan [2012] apresentam uma revisão sobre os desenvolvimentos tecnológicos que permitiram o mapeamento diferencial da rede (em várias condições) em larga escala, e sugerem que isso permite levantar questões sobre o espaço de interações inexplorado. Eles argumentam que o mapeamento diferencial da rede se tornará a forma padrão de análise de rede no futuro. Outros estudos sugerem que a combinação da abordagem GWAS com análises de transcritoma, pode reduzir o número de falsos positivos e auxiliar na descoberta de novos loci funcionais [Li et al., 2013; Nica \& Dermitzakis, 2013].

Em seu trabalho, Gaiteri et al. [2014] fazem uma revisão de como redes de co-expressão podem ser utilizadas para pesquisas envolvendo doenças complexas. Eles apresentam que várias atividades biológicas podem influenciar a expressão de dois ou mais genes e produzir padrões de expressão correlacionados. Também mostram como as alterações na estrutura de uma rede de co-expressão podem auxiliar a identificar genes candidatos de doenças. Além disso, observam que em algumas doenças psiquiátricas complexas (depressão, esquizofrenia e transtorno bipolar), genes diferencialmente expressos podem apresentar baixa conectividade.

Redes de interação proteína-proteína (PPI - Protein-Protein Intereaction) tornaram-se uma importante ferramenta para estudar as complexas relações moleculares em um organismo vivo. Elas podem, por exemplo, ser analisadas por meio de algumas medidas de centralidade (grau, betweenness, closeness, bridgeness, brokering, etc). Vários trabalhos analisaram as propriedades topológicas de redes PPI para compreender doenças genéticas [Chen et al., 2009; Kohler et al., 
2008; Lage et al., 2007; Vanunu et al., 2010] assumindo as hipóteses da network medicine [Barabási et al., 2011]. Em tais trabalhos, assumiu-se que genes conectados nas redes PPI tendem a estar associados a doenças similares (hipótese da localidade).

Métodos que analisam propriedades topológicas das redes PPI geralmente baseam-se em alguma das duas principais abordagens:

(i) local - e.g. vizinhos diretos (direct neighbors) e caminhos mínimos (shortest paths) [Wu et al., 2008];

(ii) global - e.g. passeio aleatório com reinício (RWR - Random Walk with Restart) [Chen et al., 2009; Kohler et al., 2008; Tong et al., 2007], e propagação de rede (network propagation) [Vanunu et al., 2010; Vanunu \& Sharan, 2008]).

Os métodos locais recebem críticas com relação a precisão (ex: taxa de falsos positivos). Já os métodos globais recebem críticas com relação ao viés da literatura. O impacto causado na precisão dos métodos de priorização de genes candidatos, deve-se ao fato dos dados de redes PPI serem ruidosos e incompletos [Barabási et al., 2011; Edwards et al., 2004; Hart et al., 2006], e este fato deve ser levado em consideração ao utilizá-las para o estudo de doenças. Além disso, o problema do viés da literatura (ascertainment bias) ocorre porque proteínas amplamente estudadas tendem a estar altamente conectadas, e serão favorecidas pelos métodos que avaliam as propriedades topológicas [Erten et al., 2011]. Em tais casos, proteínas que não são muito estudadas, dificilmente aparecerão entre as melhores classificadas.

O trabalho de Kohler et al. [2008] foi um dos primeiros a propor o método RWR para priorizar genes candidatos a doenças. Eles compararam os métodos globais RWR (Random Walk with Restart) e DK (Diffusion Kernel) com os métodos locais DI (Direct Interaction) e SP (Shortest Path - caminho mínimo). Ao final, eles verificaram que o método RWR encontrou resultados mais precisos, e por isso sugeriram que os métodos globais são melhores que os locais. No entanto, é digno de nota que, em sua comparação, eles não utilizaram absolutamente nenhum critério de seleção dos caminhos mínimos que refletisse características biológicas da doença; ao passo que o RWR consegue, em princípio, obter resultados aparentemente melhores (ou mais precisos) já que naturalmente prioriza as proteínas mais estudadas.

Em seguida, Vanunu et al. [2010] propôs um método chamado propagação de rede, que é uma ligeira variação do RWR, inclusive produzindo resultados bastante parecidos. Basicamente, ambos os métodos tomam como entrada: uma rede PPI, um conjunto de genes/proteínas sementes (usualmente originados a partir do GWAS), e genes candidatos; e como saída: um conjunto de genes candidatos priorizados (ranqueados por um escore/pontuação). Tais métodos investigam a vizinhança dos genes sementes a fim de priorizar genes potencialmente associados a mesma doença das sementes. Wu et al. [2008] propuseram um método chamado CIPHER baseado na medida de centralidade closeness para predizer e priorizar genes. Chen et al. [2009] foram um dos primeiros a aplicar versões estendidas dos métodos PageRank e HITS na rede PPI para priorizar genes candidatos.

Erten et al. [2011] propôs um ajuste estatístico (ver Seção 2.2.3) para resolver o problema conhecido como viés da literatura (ascertainment bias) através da aplicação de alguns ajustes 
no método RWR, cuja intenção é detectar tanto os genes de alto grau quanto os de baixo grau que estejam relacionados à doença, ao invés de priorizar apenas os genes de graus mais elevados na vizinhança das sementes ${ }^{1}$. Com a aplicação do método, eles conseguiram encontrar genes de baixo grau relacionados a doença, mas observaram que a taxa de falsos negativos aumentou. É importante lembrar que a maioria dos métodos citados até o momento baseiam-se exclusivamente na rede PPI estática e nas informações das proteínas sementes.

Para uma melhor compreensão dos mecanismos que servem de base às doenças complexas, têm sido desenvolvidas técnicas envolvendo análise integrativa de dados originados a partir de muitas fontes. Isto pode ser realizado porque existe uma grande quantidade disponível de dados genômicos, transcritômicos e proteômicos de diferentes doenças complexas em bancos de dados públicos. Assim, para melhorar a identificação e priorização de genes associados às doenças complexas, alguns trabalhos começaram a integrar redes PPI a dados de outras 'ômicas', os quais têm contribuído para uma melhor compreensão das funções gênicas, interações e vias [Kim et al., 2011; Ulitsky \& Karp, 2008]. A integração de dados de redes PPI e expressão gênica tem melhorado a classificação e identificação de vias desreguladas de doenças específicas [Chen et al., 2009; Franke et al., 2006; Keller et al., 2009; Kim et al., 2011; Suthram et al., 2008; Ulitsky \& Karp, 2008]. Uma revisão das abordagens integrativas pode ser encontrada em [Mitra et al., 2013; Ritchie et al., 2015].

Alguns trabalhos mostram diferentes formas de priorizar genes em uma rede PPI. Por exemplo, Wu et al. [2008] utilizaram correlação de expressão gênica para gerar uma rede PPI com pesos buscando refletir a dinâmica da rede sendo estudada. Eles utilizaram a medida de centralidade closeness para pontuar genes a partir de uma rede PPI integrada com fenótipos. Jia et al. [2010] modificaram o método descrito por Wu et al. [2008] a fim de pontuar genes relativamente a um conjunto de genes sementes (ver Seção 3.3 sobre cálculo de importância relativa). Eles utilizaram um conjunto de genes de estudos de meta-análises como sementes conectando-os através de caminhos mínimos e usaram closeness para computar a importância de todos os genes pertencentes a estes caminhos mínimos.

Suthram et al. [2008] desenvolveram um método envolvendo integração de dados à rede PPI usando eQTLs (expression Quantitative Trait Loci - [Cookson et al., 2009; Gilad et al., 2008; Michaelson et al., 2009; Xia et al., 2012]) para priorizar genes candidatos. Esse método integrou dados de SNPs (Single Nucleotide Polymorphisms) com dados de expressão à rede PPI para modelagem dos conjuntos de dados em um circuito elétrico de fontes de correntes e resistores. Os genes foram modelados como nós de uma rede elétrica e as interações como resistores. A voltagem de cada nó da rede foi calculada como a correlação da expressão entre os alvos e o marcador do possível gene causal. O método alcançou uma precisão de $79 \%$ na recuperação de um conjunto de referência de pares regulador-alvo na levedura, o que foi significativamente maior do que o desempenho de três métodos concorrentes na época. Com isso, surgiram vários outros trabalhos que se basearam nesse modelo. Kim et al. [2011] basearam-se nesse modelo do circuito elétrico para identificação de vias desreguladas. Foram integrados dados do interatoma humano com dados do perfil de expressão gênica de 158 pacientes de Glioblastoma multiforme e 32 controles

${ }^{1}$ Nesse contexto, sementes são proteínas (ou genes) sabidamente associadas à doença em estudo. 
- a diferença de expressão foi utilizada para encontrar os genes alvos. Para encontrar os possíveis genes causais, foram utilizados apenas SNPs que são eQTLs. Alguns tratamentos estatísticos foram utilizados para refinar a lista de genes causais. Um circuito elétrico foi modelado a partir de dados de interatoma, sendo os genes/proteínas modelados como nós, e as arestas (interações) como resistores. O valor da condutância de resistor entre dois nós foi calculado como a média das correlações entre cada nó e o gene alvo. Em seguida, anexou-se uma fonte de corrente no gene causal e solucionou-se o sistema linear elétrico. A via desregulada era inferida como aquela com maior corrente. Todo esse processo foi repetido para cada par de genes causal e alvo, obtendo a via mais provável para cada par de genes ${ }^{1}$. O objetivo de Kim et al. [2011] ao fazerem isso, era encontrar alguma causalidade, ou seja, de que forma um dado SNP está modulando a expressão de um gene intermediário entre os genes causais e os alvos. No entanto, em nosso trabalho usamos a integração com dados de expressão não para encontrar alguma causalidade, e sim para comparar estados diferentes entre caso e controle.

Kumari et al. [2012] fizeram uma comparação de 8 métodos de associação ${ }^{2}$ diferentes para encontrar genes co-expressos em vias a fim de construir redes de co-expressão. Eles examinaram o comportamento dos diferentes métodos aplicados a dados de microarray com propriedades diferentes e se os processos biológicos afetam a eficiência de cada método. Pode-se destacar que eles descobriram que os métodos Spearman, Kendall e Hoeffding são eficazes em identificar vias de genes co-expressos, ao passo que os métodos Theil-sen, Rank Theil-Sen, Spearman e Weighted Rank apresentaram bons desempenhos em identificar fatores de transcrição que controlam os mesmos processos e traços biológicos.

Uma revisão das abordagens de integração de dados visando descobrir as interações entre genótipo e fenótipo pode ser encontrada em [Ritchie et al., 2015]. Eles classificaram a integração de dados em dois tipos: (i) análise multi-estágio e análise meta-dimensional. O principal objetivo da abordagem multi-estágio é dividir a análise em vários passos para encontrar associações primeiro entre os diferentes tipos de dados, e então, posteriormente, entre os tipos de dados e o traço ou fenótipo de interesse. A análise meta-dimensional combina múltiplos tipos de dados em uma análise simultânea. Uma importante consideração feita por eles nas análises de larga escala, é o potencial para falsas descobertas. Desta forma, é interessante determinar uma maneira de identificar resultados com maiores chances de serem associações verdadeiras e não falsos positivos. Segundo eles, verificar a replicação dos resultados usando dados independentes, e buscar a replicação dos modelos multi-ômicos é uma forma de identificar modelos preditivos robustos. Outra preocupação é a validação dos resultados, que pode ser feita através de experimentos biológicos e através de mineração de textos para encontrar literatura que suporta ou refuta os achados originais.

\subsubsection{Viés da literatura e os métodos RWR e DADA}

O passeio aleatório com reinício (RWR - Random Walk with Restart) [Tong et al., 2007] é um método global que é frequentemente aplicado para priorização de genes relacionados à doença [Kohler et al., 2008]. A partir de um conjunto de genes (sementes) associados a uma doença, o

\footnotetext{
${ }^{1}$ Este método demorou cerca de 60 horas em um cluster com diversas máquinas paralelas.

${ }^{2}$ Foram comparados os métodos Spearman rank correlation, Weighted Rank Correlation, Kendall, medida $D$ de Hoeffding, Theil-Sen, Rank Theil-Sen, Covariância da Distância, e Pearson.
} 
método utiliza a rede PPI para priorizar os genes candidatos. A pontuação de um gene candidato fornecida pelo método RWR pode ser calculada de forma iterativa através da Equação2.14.

$$
p^{t+1}=(1-r) W p^{t}+r p^{0}
$$

Aqui, $W$ é a matriz de adjacência da rede. O vetor $p^{t}$ armazena em seu $i$-ésimo elemento a probabilidade de o passeio aleatório estar no nó $i$ no instante de tempo $t$. Além disso, $p^{0}$ é o vetor de probabilidades inicial e $r$ é a probabilidade de reiniciar o passeio aleatório, voltando a algum nó semente. Entretanto, conforme já mencionado as redes PPI possuem um viés na distribuição do seu grau - conhecido como viés da literatura (ascertainment bias) [Erten et al., 2011], pois proteínas amplamente estudadas na literatura geralmente possuirão mais interações conhecidas e associações com doenças comparadas com aquelas que são menos estudadas. Visando contornar tal problema, [Erten et al., 2011] propuseram um conjunto de métodos de ajuste estatístico (chamado DADA - do inglês Degree-Aware Algorithms for Network-Based Disease Gene Prioritization) para corrigir esse viés nos métodos globais de priorização de genes da doença. Enquanto RWR detecta apenas genes com graus mais elevados na vizinhança das sementes, o método DADA busca detectar genes relacionados à doença que tenham graus altos e baixos. Eles apresentaram três ajustes estatísticos baseados em três aspectos: (i) grau das sementes, (ii) grau dos candidatos e (iii) teste da taxa de verossimilhança usando centralidade de autovetores ${ }^{1}$. Eles observaram que os resultados do ajuste estatístico levaram a falsos negativos e, para contornar esse problema, criaram três estratégias de priorizações uniformes: (i) priorização uniforme; (ii) priorização uniforme baseada no grau do gene candidato; (iii) priorização uniforme otimística. Basicamente atuam de alguma forma mesclando os ranqueamentos gerados pelos dois métodos RWR e DADA. Assim, a utilização do método DADA é realizada através da integração de um dos três ajustes estatísticos diferentes, bem como por utilizar um de três diferentes métodos de priorização. Após a realização dos testes, observaram que $r=0,3$ foi o valor ótimo para a probabilidade de reinício, e consideraram que o ajuste estatístico baseado na centralidade juntamente com o método de priorização baseada no grau das sementes foi a configuração vencedora - apesar dos resultados serem bastante semelhantes. Desta forma, métodos existentes na literatura, tais como o RWR, Network Propagation, PageRank e HITS tendem a favorecer fortemente genes de mais alto grau na vizinhança dos genes sementes. Já métodos como o DADA, procuram reduzir este efeito por aumentar a prioridade de genes com graus mais baixos. Neste trabalho, os métodos RWR e DADA serão levados em consideração na análise comparativa da Seção 5.3.

${ }^{1}$ (Likelihood-ratio test using eigenvector centrality) 



\section{Capítulo 3}

\section{Metodologia Proposta para Priorização de Genes}

Este capítulo descreve a metodologia utilizada para tratamento dos dados e implementação do algoritmo, a fim de selecionar os genes segundo alguns critérios pré-definidos. A metodologia proposta busca - através da integração de dados de redes PPI (Protein-Protein Interaction - Interação Proteína-Proteína) com dados de expressão, além de uma lista de genes sementes - encontrar genes (e arestas/interações) que estejam mais relacionados com a doença em estudo, fazendo uma comparação entre dados de expressão gênica de duas condições: caso e controle.

\subsection{Visão Geral}

Neste trabalho, propomos uma abordagem integrativa baseada nas hipóteses da Network Medicine cujo principal objetivo é encontrar genes e processos biológicos que expliquem um fenótipo de doença complexa comparado a controles. A abordagem desenvolvida também tem como objetivo melhorar a replicabilidade entre os diferentes estudos de expressão gênica que não apresentaram qualquer replicação anterior - baixa interseção entre as listas de genes. A fim de alcançar tais objetivos, desenvolvemos uma metodologia que integra dados de rede PPI, expressão gênica e genes oriundos de estudos de associação (conhecidos por estarem relacionados à doença). A rede PPI é representada por um grafo em que os vértices são os genes/proteínas e as arestas são as interações entre dois genes/proteínas.

Neste trabalho, o método desenvolvido utiliza caminhos simples e a definição de caminho mínimo [Barabási et al., 2011; Managbanag et al., 2008] entre dois vértices como aquele com o menor número possível de arestas, ou seja, sem pesos. É possível haver outras definições de caminhos mínimos como, por exemplo, usar grafos com pesos nas arestas e definir caminho mínimo como aquele com a menor soma dos pesos das arestas. Apesar dos grafos terem pesos nas arestas, optou-se por utilizar a definição de caminhos mínimos sem considerar estes pesos. A Figura 3.1 ilustra que é possível haver mais de um caminho mínimo entre dois genes $s$ e $t$ de uma rede PPI e, por isso, é necessário haver uma forma de selecionar algum caminho mais relevante biologicamente. Na verdade, a quantidade de caminhos possíveis entre dois genes da rede PPI pode chegar 
a centenas (ver Figura 5.1 que mostra a distribuição de caminhos mínimos no interatoma).

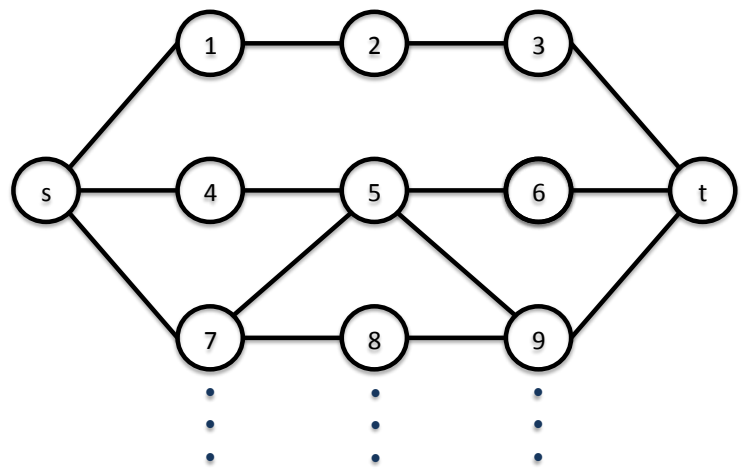

Figura 3.1: Ilustração dos múltiplos caminhos mínimos que podem haver entre duas proteínas s e t da rede PPI, sugerindo a necessidade de se ter um critério que selecione o caminho mais relevante biologicamente.

Basicamente, a metodologia proposta integra redes PPI com dados de expressão gênica em duas condições (controle e doença) e um conjunto de genes (sementes) obtidos de estudos de associação. Após a integração de dados, avalia-se a co-expressão dos genes sementes com os demais genes em sua vizinhança, atribuindo-lhes uma pontuação. Esta co-expressão é calculada individualmente para dados de expressão de controle e de doença, resultando em duas pontuações independentes para cada gene (controle e doença) - chamamos este processo de cálculo da importância relativa. Ao final, realizamos a comparação das pontuações de importância (características) do passo anterior para selecionar os genes mais alterados nas duas condições e potencialmente mais relacionados à doença. Uma visão esquemática da metodologia proposta neste trabalho é apresentada na Figura 3.2, e esta contém 3 partes principais:

\section{(i) Integração de dados}

na qual são realizados diversos tipos de pré-processamento nos dados (rede PPI e expressão gênica), mapeamento de proteínas da rede PPI e dos transcritos dos dados de expressão em seus respectivos genes. Em seguida, é realizada a integração da rede PPI aos dados de expressão;

\section{(ii) Cálculo da importância relativa}

em que, pela aplicação das hipóteses módulo de doença e parcimônia de rede, são avaliadas as importâncias relativas dos genes candidatos em relação aos genes sementes. A importância relativa é calculada considerando aspectos de co-expressão (em duas condições: doença e controle) e aspectos topológicos. Com isso, são produzidas duas características (escores de importâncias relativas) para os genes referentes às condições controle e doença;

\section{(iii) Análise diferencial da Rede PPI}

em seguida, as características (escores de importâncias relativas) calculadas na etapa anterior são utilizadas para analisar o grau de alteração dos genes nas duas condições, e estas serão consideradas para descobrir genes candidatos à doença. Com isso, busca-se encontrar os genes potencialmente mais relevantes no sentido biológico - que são os genes mais alterados entre as duas condições. 
O processo descrito acima também é aplicado às arestas/interações, o qual é combinado com os genes selecionados para construir uma sub-rede final dos genes e interações que estiverem mais alterados entre as duas condições. Embora o método possa ser aplicado da mesma forma para as interações, neste trabalho estão sendo analisados somente os genes. Nas próximas seções, serão apresentadas de forma mais detalhada cada parte deste método.

\subsection{Integração de Dados}

Nesta etapa é realizada a construção da rede PPI (integrando diversos bancos de dados disponíveis) que, em seguida, tem suas proteínas mapeadas nos respectivos genes que as codificam. Também é realizado o mapeamento dos transcritos dos dados de expressão em seus respectivos genes de origem. Apenas os 'genes' ${ }^{1}$ presentes em ambos - nos mapeamentos da rede PPI anterior e dos dados de expressão - são utilizados para construção da rede PPI integrada. O conjunto de genes sementes é integrado de forma que contenha apenas genes que estejam presentes na rede PPI integrada. Os dados de expressão são separados nas amostras de doença e controle.

\footnotetext{
${ }^{1} \mathrm{Na}$ verdade, são proteínas que foram mapeadas em seus respectivos genes. De agora em diante, utilizaremos, no contexto de redes PPI, o termo 'genes' referindo-se às suas respectivas proteínas.
}

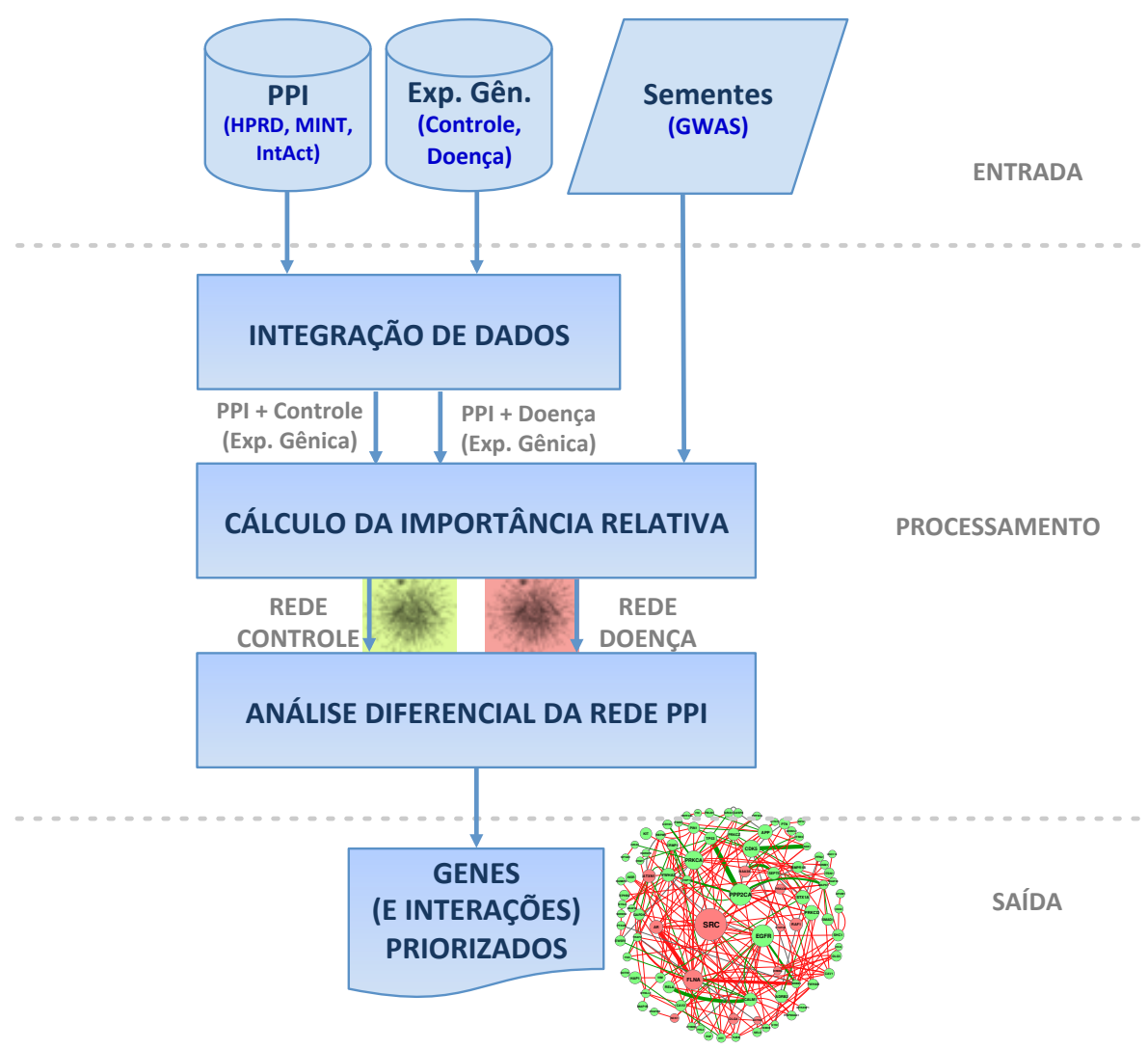

Figura 3.2: Visão geral da metodologia. 


\subsubsection{Integração da Rede PPI com os Dados de Expressão}

Ao integrar dados entre genes, transcritos e proteínas, é importante ter em mente que um único gene pode gerar vários transcritos que, consequentemente, serão traduzidos em várias proteínas. Por esta razão, é possível que diferentes proteínas, bem como diferentes transcritos, sejam mapeadas(os) para um mesmo gene - que os originou.

Assim, para realizar a integração entre dados da rede PPI e dados de expressão, primeiramente é necessário mapear as proteínas da rede PPI para seus respectivos genes. Isto ocorre porque os dados de PPI representam interações entre proteínas e não exatamente entre genes. A rede PPI é representada por meio de um grafo não-dirigido (pois geralmente os bancos de dados de PPI não possuem informações de direcionalidade) onde os nós são proteínas e as arestas representam as interações entre duas proteínas. Para a construção dessa rede PPI, realiza-se a composição de diversos bancos de dados de PPI, formando uma única rede PPI final representando a união de todas as proteínas e interações dos bancos. É importante notar que critérios diferentes para a união destes bancos podem trazer maior ou menor grau de confiabilidade a rede final, por exemplo, podemos usar apenas dados de interações produzidas na bancada, ou acrescentar as preditas por computador. Além disso, podemos usar a união de todos os bancos ou usar, por exemplo, apenas as interações presentes em, pelo menos, dois bancos ou em todos os bancos.

Analogamente, dados de expressão são provenientes de transcritos e também devem ser mapeados nos genes que os originam. Dependendo da fonte dos dados, pode ser necessária aplicar algum processo de normalização. Após a normalização, em casos onde há diversos transcritos mapeados para o mesmo gene, utilizamos a mediana para representar a expressão do respectivo gene. A Figura 3.3 ilustra um caminho na rede PPI após integrá-la com dados de expressão. Cada gene da rede fica associado a um vetor de expressões gênicas que serão utilizadas para a seleção do caminho que contenha genes mais co-expressos.

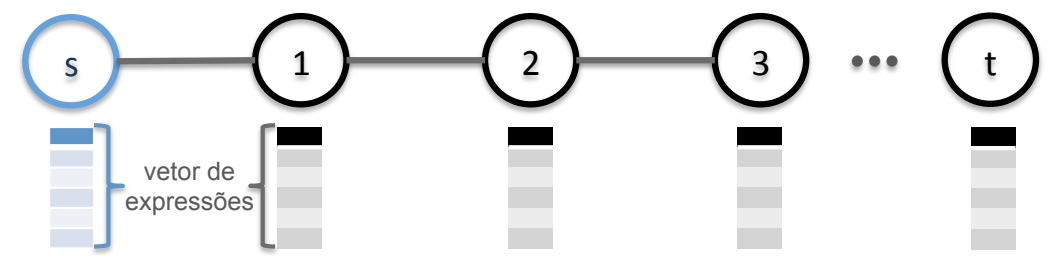

Figura 3.3: Ilustração de um caminho da rede PPI após a integração com dados de expressão. Cada gene da rede está associado a um vetor de expressões.

Após o mapeamento da rede PPI e dos dados de expressão dos transcritos para seus respectivos genes originais, é possível fazer a integração de dados. No entanto, pode acontecer que nem todos os genes presentes no mapeamento da rede PPI estejam presentes no mapeamento dos transcritos e vice-versa. Para garantir que todos os 'genes' presentes na nova rede PPI integrada tenham correspondentes nos dados de expressão, somente os 'genes' presentes simultaneamente na rede PPI original e nos dados de expressão permanecem na nova rede PPI integrada. 


\subsection{Cálculo da Importância Relativa}

Após a integração de dados da etapa anterior, assumimos as hipóteses da localidade, de módulo de doença e princípio da parcimônia da rede (descritos na Seção 2.2.1) para calcular a importância relativa [White \& Smyth, 2003] dos genes na vizinhança dos genes sementes - visando descobrir genes potencialmente relacionados à doença em questão. Visto que a rede PPI é estática e genérica, integramos dados de expressão em duas condições (controle e doente) à rede PPI para tornar possível a diferenciação entre seus estados. Aplicando a hipótese de localidade, buscamos na rede integrada por um conjunto de genes vizinhos de interação direta $(N)$ aos genes sementes $(S)$, e com isso definimos um novo conjunto de genes $(S \cup N)$.

\subsubsection{Seleção dos Caminhos Mínimos}

Pela hipótese de módulo de doença, sabemos que genes relacionados às mesmas doenças tendem a formar módulos (ou grupos de genes próximos - na mesma vizinhança) em regiões da rede PPI. Aplicando o princípio da parcimônia de rede, visamos encontrar outros genes potencialmente relacionados à doença e, para isso, investigamos os genes intermediários $(I)$ pertencentes aos caminhos mínimos entre $S$ e $(S \cup N)$. Diversos trabalhos [Aittokallio \& Schwikowski, 2006; Chuang \& Roth, 2001; Managbanag et al., 2008; Missiuro et al., 2009; Przulj et al., 2004; Sun et al., 2010] utilizaram o algoritmo de caminhos mínimos para inferir vias biológicas e/ou sub-redes entre grupos de genes relacionados à doença, e mostraram que os genes intermediários obtidos também estavam relacionados à doença. Entretanto, um par de genes pode estar conectado através de vários caminhos mínimos na rede PPI, sendo que os algoritmos em geral retornam aleatoriamente um deles (ver ilustração apresentada na Figura 3.1). Neste caso, o caminho retornado pode depender da implementação do algoritmo - que pode variar dependendo da biblioteca adotada, bem como da ordem de armazenamento dos dados na memória, etc. Desta forma, quando uma função de uma dada biblioteca retorna um caminho mínimo, este pode ter sido escolhido arbitrariamente entre diversos outros possíveis e isto pode não ser uma estratégia eficiente para encontrar os caminhos contendo genes mais relevantes ao problema biológico.

Partindo do princípio que genes co-expressos tendem a estar funcionalmente relacionados [Stuart et al., 2003], nossa hipótese é que genes mais correlacionados com os genes sementes tenderão a estar associados com à doença. Assumimos então que caminhos mínimos contendo genes mais co-expressos com as sementes terão maiores chances de conter genes que participem dos processos biológicos da doença, possivelmente formando um módulo/agrupamento (ver conceitos módulo de doença e date hub na subseção 2.2.1). Assim, a idéia é estabelecer um critério que use dados de expressão gênica para encontrar os caminhos mínimos contendo os genes mais co-expressos entre si e com os genes sementes. A Figura 3.4 ilustra a seleção caminhos mínimos utilizando dados de expressão em duas condições diferentes, por exemplo: controle e doença. Em cada condição, será selecionado o caminho que contiver os genes mais co-expressos. Para isso, utilizamos uma versão modificada do coeficiente de concordância de Kendall (ver Seção 3.3.2) [Kendall \& Smith, 1939; Kumari et al., 2012]. 


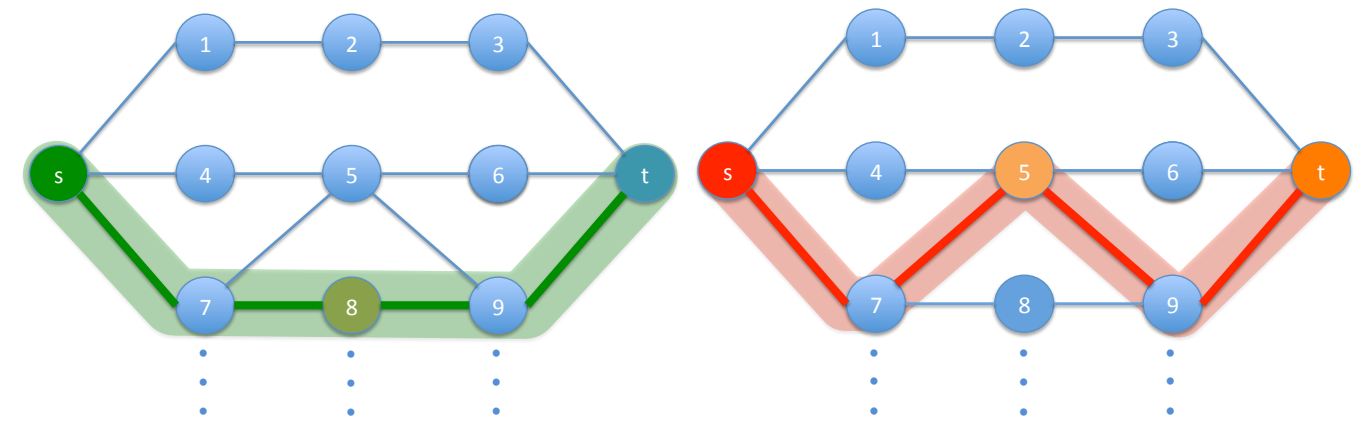

Figura 3.4: Ilustração da seleção de um caminho mínimo utilizando dados de expressão em duas condições diferentes, por exemplo: controle e doença.

\section{Seleção de um Único Caminho Mínimo por Par}

O método proposto seleciona caminhos mínimos que apresentarem maiores valores $\left(W_{\max }\right)$ de concordância de Kendall modificado (ver Seção 3.3.2) - buscando encontrar regiões da rede PPI que estejam co-expressas com os genes sementes. Ao selecionar um único caminho mínimo por par, existem situações em que diversos pares apresentam vários caminhos mínimos com valores de $W_{\max }$ muito próximos do valor do caminho de maior concordância. Por exemplo, suponha que um dado par de genes possua diversos caminhos mínimos com seus respectivos valores $W_{\max }-$ ordenados decrescentemente - conforme ilustrado na Tabela 3.1.

É possível observar que o segundo maior valor $(0,55103)$ é muito próximo do maior valor $(0,55634)$, situação que chamamos de 'empate técnico'. Em tais situações pode ser interessante considerar mais de um caminho mínimo por par, para evitar perder informação relevante, por exemplo, em casos onde caminhos altamente co-expressos não sejam selecionados devido a outro caminho ser ligeiramente mais co-expresso que eles, fazendo com que genes importantes não sejam selecionados pelo método.

\section{Seleção dos $K$ Menores Caminhos (K-shortest paths)}

Um forma de selecionar múltiplos caminhos mínimos bastante conhecida na literatura é através do algoritmo $K$-shortest paths [Eppstein, 1998], em que $K$ caminhos mínimos são selecionados. No entanto, devido ao fato do parâmetro $K$ ser fixo, pode haver problemas, pois nada garante que todos os pares de genes avaliados possuam $K$ caminhos praticamente empatados e, neste caso, forçar a busca em $K$ caminhos pode resultar em caminhos não relevantes. Além disso, em outras situações é possível que o valor $K$ seja menor que o número de caminhos empatados entre os primeiros colocados, persistindo assim o problema de deixar de selecionar caminhos relevantes. Devido a tais considerações, ao invés de obter os $K$ melhores caminhos, adotamos como solução obter os caminhos mínimos que estejam empatados segundo um fator $\epsilon$, conforme será visto a seguir.

\section{Seleção dos caminhos mínimos segundo um fator ( $\epsilon$-shortest paths)}

Para lidar com casos de empates e ao mesmo tempo evitar problemas devido a um número fixo de caminhos, adotamos a utilização de um fator $\epsilon$ como critério para definir o empate entre caminhos. 


\begin{tabular}{|c|r|l|}
\hline Rank & $W_{\max }$ & Caminho Mínimo \\
\hline \hline 1 & 0.55634 & ['AKT1', 'ESR1', 'RPS6KA3', 'HTR2A'] \\
\hline 2 & 0.55103 & ['AKT1', 'BAD', 'RPS6KA3', 'HTR2A'] \\
\hline 3 & 0.53109 & ['AKT1', 'YWHAZ', 'EIF3F', 'HTR2A'] \\
\hline 4 & 0.52399 & ['AKT1', 'TSC1', 'EIF3F', 'HTR2A'] \\
\hline 5 & 0.50004 & ['AKT1', 'PPP2R1A', 'PPP5C', 'HTR2A'] \\
\hline 6 & 0.49905 & ['AKT1', 'ESR1', 'GNAI1, 'HTR2A'] \\
\hline 7 & 0.49538 & ['AKT1', 'CREB1', 'RPS6KA3', 'HTR2A'] \\
\hline 8 & 0.48942 & ['AKT1', 'PPP2CA', 'JAK2', 'HTR2A'] \\
\hline 9 & 0.48835 & ['AKT1', 'NR4A1', 'RPS6KA3', 'HTR2A'] \\
\hline 10 & 0.47552 & ['AKT1', 'SH2B2', 'JAK2', 'HTR2A'] \\
\hline 11 & 0.47257 & ['AKT1', 'CDC37', 'PPP5C', 'HTR2A'] \\
\hline 12 & 0.46261 & ['AKT1', 'ITGB3', 'ANKS1B', 'HTR2A'] \\
\hline 13 & 0.45222 & ['AKT1', 'IRS1', 'JAK2', 'HTR2A'] \\
\hline 14 & 0.44679 & ['AKT1', 'HTT', 'DLG4', 'HTR2A'] \\
\hline 15 & 0.44668 & ['AKT1', 'PIK3R1', 'JAK2', 'HTR2A'] \\
\hline 16 & 0.44240 & ['AKT1', 'PDPK1', 'RPS6KA3', 'HTR2A'] \\
\hline 17 & 0.42693 & ['AKT1', 'MTOR', 'EIF3F', 'HTR2A'] \\
\hline 18 & 0.41971 & ['AKT1', 'SRC', 'JAK2', 'HTR2A'] \\
\hline 19 & 0.41883 & ['AKT1', 'IRAK1', 'NTRK3', 'HTR2A'] \\
\hline 20 & 0.41283 & ['AKT1', 'MAP3K5, 'PPP5C', 'HTR2A'] \\
\hline 21 & 0.40359 & ['AKT1', 'PEA15', 'RPS6KA3', 'HTR2A'] \\
\hline 22 & 0.40180 & ['AKT1', 'BRCA1', 'JAK2', 'HTR2A'] \\
\hline 23 & 0.39859 & ['AKT1', 'NR4A1', 'MPDZ', 'HTR2A'] \\
\hline 24 & 0.39610 & ['AKT1', 'S1PR1', 'GNA1', 'HTR2A'] \\
\hline 25 & 0.39374 & ['AKT1', 'SRC', 'DLG4', 'HTR2A'] \\
\hline 26 & 0.39324 & ['AKT1', 'ESR2', 'PPP5C', 'HTR2A'] \\
\hline 27 & 0.38832 & ['AKT1', 'PTPN1', 'JAK2', 'HTR2A'] \\
\hline 28 & 0.38308 & ['AKT1', 'MST1R', 'JAK2', 'HTR2A'] \\
\hline 29 & 0.38205 & ['AKT1', 'ESR1', 'PPP5C', 'HTR2A'] \\
\hline 30 & 0.38147 & ['AKT1', 'PLCG1', 'JAK2', 'HTR2A'] \\
\hline 31 & 0.38018 & ['AKT1', 'PLCG1', 'NTRK3', 'HTR2A'] \\
\hline 32 & 0.37113 & ['AKT1', 'PTPN1', 'NTRK3', 'HTR2A'] \\
\hline 33 & 0.37109 & ['AKT1', 'GRB10', 'JAK2', 'HTR2A'] \\
\hline 34 & 0.36241 & ['AKT1', 'HSP90AB1', 'PPP5C', 'HTR2A'] \\
\hline 35 & 0.35439 & ['AKT1', 'STAT1', 'JAK2', 'HTR2A'] \\
\hline 36 & 0.33740 & ['AKT1', 'HSP90AA1', 'PPP5C', 'HTR2A'] \\
\hline 37 & 0.33648 & ['AKT1', 'RAF1', 'JAK2', 'HTR2A'] \\
\hline
\end{tabular}

Tabela 3.1: Ilustração de caminhos mínimos possíveis - existentes entre um dado par de genes - e seus respectivos valores do coeficiente de Concordância de Kendall Modificado $\left(W_{\max }\right)$ - ordenados decrescentemente. Note que o segundo maior valor $(0,55103)$ é muito próximo do primeiro $(0,55634)$ - 'empate técnico'. Nesse caso pode ser interessante considerar múltilplos caminhos mínimos por par, para evitar perder informação relevante. 
Este fator $\epsilon$ é definido como um percentual relativo ao valor de concordância do melhor caminho. Seja $W_{\max }\left(P^{*}\right)$ a concordância do melhor caminho $P^{*}$ para um dado par de genes. Consideramos empatados os caminhos $P_{i}$ que tiverem concordância $W_{\max }\left(P_{i}\right)>=W_{\max }\left(P^{*}\right)(1-\epsilon)$. Por exemplo, suponha que $W_{\max }\left(P^{*}\right)=0,6$ e $\epsilon=0,05$. Então serão considerados empatados os caminhos que tiverem concordância $W_{\max }$ de no mínimo $0,6 \times(1-0,05)=0,57$.

\subsubsection{Coeficiente de Concordância de Kendall Modificado}

Conforme visto na Seção 2.1.4, o coeficiente de concordância de Kendall [Kendall \& Smith, 1939] pode ser utilizado para avaliar a concordância global entre um conjunto de avaliadores. Por exemplo, os avaliadores podem ser vetores de expressões de alguns genes em um dado caminho mínimo e, quanto maior a concordância entre eles maior será a co-expressão. No entanto, devido a algumas considerações biológicas, foi necessário realizar algumas adaptações no coeficiente de concordância de Kendall para que ele possa ser utilizado na seleção dos caminhos.

Para entender melhor, tome como exemplo dois genes que estejam regulados negativamente (down-regulated ) - quando a expressão de um deles aumenta, a expressão do outro diminui e viceversa. Neste caso, a correlação entre eles tenderá apresentar valor próximo de -1 , e isto indica que eles são altamente correlacionados mesmo sendo de forma negativa. Em muitas análises biológicas, não importa se dois genes estão regulados positiva ou negativamente (up/down-regulated) e sim o quanto eles estão correlacionados entre si. Ou seja, não importa o sinal da correlação, apenas o seu valor absoluto.

Lembrando que o coeficiente de concordância de Kendall apresenta valores que variam de 0 (nenhuma concordância) a 1 (concordância total) - o que é diferente dos valores assumidos por correlação que variam de -1 a 1 - então a concordância de Kendall aplicada diretamente apresentará problema quando os genes estiverem regulados negativamente. Para ilustrar, tome como exemplo 4 genes (ver Figura 3.5) altamente correlacionados entre si, mas que os dois primeiros possuam expressão em ordem crescente e os dois últimos em ordem decrescente. Dessa forma, o coeficiente de concordância de Kendall entre eles será próximo de 0 , mesmo eles estando altamente correlacionados entre si. Para solucionar isso é necessário inverter a ordem de ranqueamento (postos) dos dois últimos genes - fazendo com que os 4 genes fiquem alinhados e seja obtido o valor máximo de concordância. Isto visa capturar somente a informação biológica de quanto eles são concordantes entre si resultando no maior valor possível de concordância de Kendall.

Como estamos interessados em calcular a concordância de Kendall independentemente dos genes estarem regulados positiva ou negativamente, adaptamos o cálculo desse coeficiente para contemplar estes casos. Assim, para os $m$ genes de um caminho, são realizadas todas as $2^{m}$ combinações de inversões de ranqueamento possíveis e, para cada uma dessas combinações, calcula-se a concordância de Kendall. O valor máximo obtido neste processo $\left(W_{\max }\right)$ representará a concordância de Kendall modificada para os genes contidos em um dado caminho.

Desta forma, independentemente dos genes estarem regulados positiva ou negativamente, será calculada uma pontuação baseada na concordância de Kendall entre eles, a qual representa melhor as informações biológicas que desejamos capturar. O procedimento proposto é de complexidade exponencial, mas como a PPI é uma rede small-world (Barabási et al., 2011) cujo diâmetro (maior 


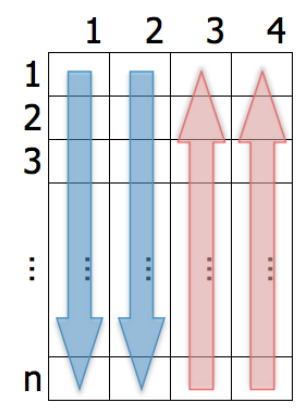

Figura 3.5: Ilustração do problema do coeficiente de concordância de Kendall quando se tem genes regulados negativamente. As colunas representam os genes e as linhas os postos dos dados de expresão referente a cada gene. Suponha que, para uma dada amostra, os genes 1 e 2 tenham perfis de expressão estritamente crescentes e os genes 3 e 4 tenham perfis de expressão estritamente decrescentes. Neste caso,todos os pares de genes estão fortemente correlacionados (positiva ou negativamente), mas o coeficiente de concordância de Kendall (W) será zero. Assim, primeiro é necessário inverter o ranqueamento de alguns genes (ex: 3 e 4) para obter o valor máximo do coeficiente de concordância de Kendall (W).

distância entre dois vértices na rede) é limitado, esta computação pode ser realizada em um tempo razoável.

\subsubsection{Importância relativa dos genes em uma dada condição}

O processo mencionado na Subseção 3.3.1 é repetido para todas as combinações de pares de genes $(s, t) \in S \times(S \cup N)$. São selecionados os caminhos mínimos que possuírem as maiores pontuações (concordância de Kendall modificada - ver Seção 3.3.2). Para o cálculo da concordância de Kendall modificada, são utilizados dois conjuntos de dados de expressão gênica (controle e doente), e isto fará com que sejam selecionados caminhos diferentes para cada dado de expressão (controle e doente). Isto resultará em duas medidas de escores para cada gene - uma referente ao controle $\left(\sigma_{C}\right)$ e outra ao doente $\left(\sigma_{D}\right)$.

Inspirado em alguns trabalhos [Jia et al., 2010; White \& Smyth, 2003], derivamos um escore (pontuação) para avaliar a importância relativa de um dado gene considerando aspectos topológicos e transcricionais (expressão gênica) em uma dada condição (sub-rede de doença ou controle) para genes pertencentes aos caminhos mínimos selecionados na seção anterior. No que tange os aspectos topológicos, utilizamos conceitos similares a closeness e betweenness e quanto aos aspectos transcricionais, usamos o valor $W_{\max }$ para medir o quanto genes de um dado caminho estão co-expressos. Considerando todos estes aspectos, propusemos a Equação 3.1 para pontuar a importância relativa de um gene em relação aos genes sementes em uma dada condição (controle ou doença):

$$
\begin{aligned}
& \sigma(g)=\quad \sum \quad \lambda^{-d_{s g}} \times W_{\max }\left(P_{s t}\right) \times \mathbf{1}_{g \in P_{s t}} \\
& s \in S \\
& t \in S \cup N \\
& P_{s t} \in \mathcal{P}_{s t}^{*}
\end{aligned}
$$


em que $d_{s g}$ é a distância de um gene semente $s$ ao gene $g$ na rede PPI, $W_{\max }$ é a concordância de Kendall modificada, $\mathcal{P}_{s t}^{*}$ é o conjunto dos caminhos mínimos selecionados de $s$ a $t$, e $\mathbf{1}_{g \in P_{s t}}$ é a função indicadora que retorna 1 se $g$ pertence a $P_{s t}$ e 0 caso contrário.

$\mathrm{O}$ primeiro termo $\left(\lambda^{-d_{s g}}\right)$, atua de forma similar à medida closeness, buscando penalizar a distância entre um gene semente $s$ e um dado gene $g$. A Figura 3.6 ilustra este efeito de decaimento, ou seja, quanto maior for a distância $d_{s g}$ do gene semente $s$ ao gene $g\left(d_{s g}=1,2,3, \ldots\right)$, menor será a importância relativa do gene $g\left(I_{g}=\lambda^{-1}, \lambda^{-2}, \lambda^{-3}, \ldots, \operatorname{com} \lambda>1\right)$.

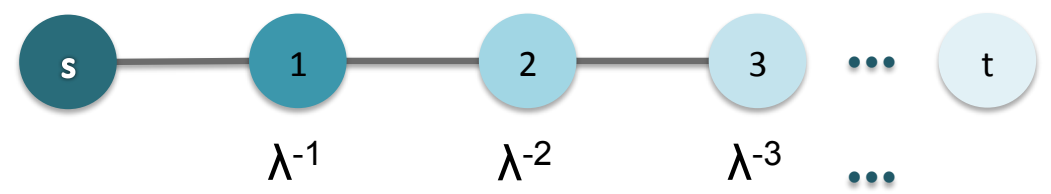

Figura 3.6: Ilustração do efeito de decaimento, ou seja, quanto mais distante o gene g estiver do gene semente s, menor será sua importância relativa.

Em relação aos aspectos transcricionais, usamos o valor $W_{\max }$ para medir o quão co-expressos estão os genes de um dado caminho. Assim, o segundo termo $\left(W_{\max }\left(P_{s t}\right)\right)$ da Equação 3.1 mede a concordância dos genes pertencentes a um caminho mínimo que contém o gene $g$. Este termo procura beneficiar genes que pertencem aos caminhos mínimos altamente co-expressos - em termos de expressão gênica. Desta forma, se um gene estiver próximo a um gene semente mas não estiver em um caminho co-expresso com ele, então o gene terá seu escore penalizado. O último termo $\left(\mathbf{1}_{g \in P_{s t}}\right)$, faz com que apenas genes pertencentes aos caminhos mínimos selecionados sejam considerados, tendo escore não nulo.

Assim, a Equação 3.1 mede o escore de um gene em uma dada condição e assume aditividade da contribuição de todas as sementes a ele. Esta equação é aplicada separadamente às sub-redes de controle e doença, resultando em dois valores de escores $\sigma_{C}(g)$ e $\sigma_{D}(g)$ - para as condições de controle e doença, respectivamente. Esses dois escores representam, em duas condições, as importâncias relativas de cada gene aos genes sementes, e serão comparados a fim de obter genes potencialmente mais relevantes.

\subsection{Seleção dos Genes}

Após a etapa anterior, cada gene estará associado a dois escores de importância relativa (em duas condições diferentes) com que ocorreram nos caminhos selecionados. Assumimos, como hipótese, que os genes que apresentarem as alterações mais relevantes entre os escores de controle $\left(\sigma_{C}\right)$ e doente $\left(\sigma_{D}\right)$ tenham uma maior chance de estarem relacionados à doença, desejamos uma forma eficaz de encontrar os genes mais alterados.

\subsubsection{Transformação similar ao método MAID}

Encontrar os genes mais alterados assemelha-se ao problema de encontrar genes diferencialmente expressos (conforme visto na Seção 2.1.5), bastante discutido na literatura [Dudoit et al., 2002; Hecker et al., 2009; Vêncio \& Koide, 2005]. Dentre os métodos propostos na literatura para encontrar genes alterados, podemos destacar o método paramétrico MAID. Baseando nesse método, 
propusemos algumas alterações que utilizam os escores $\left(\sigma_{C}, \sigma_{D}\right)$ - vistos anteriormente - para obter os genes mais alterados em duas condições. Para isso, realizamos duas transformações similares as transformações do método MA-plot - uma referente a intensidade $A$ e outra referente as variações $M$.

\section{Intensidade}

Para obter uma medida similar a intensidade $A$ (eixo das abscissas $x$ ) do método MA-plot, utilizamos a Equação 3.2:

$$
X(g)=\sigma_{C}(g)+\sigma_{D}(g)
$$

\section{Escore de alteração}

Para a segunda transformação, relativa a variação $M$ (eixo das ordenadas $y$ ), desenvolvemos um escore de alteração $(\Delta)$ para comparar os escores $\sigma_{C}$ e $\sigma_{D}$ computados para os genes em nossa sub-rede, conforme apresentado na Equação 3.3:

$$
\Delta(g)=\frac{\sigma_{D}(g)-\sigma_{C}(g)}{\sigma_{C}(g)+\sigma_{D}(g)}=\frac{\sigma_{D}(g)-\sigma_{C}(g)}{X(g)}
$$

Esta equação procura medir a diferença relativa dos scores $\sigma_{C}(g)$ e $\sigma_{D}(g)$ de um gene $g$ entre duas condições (controle e doença). A faixa de valores varia de $-1 \mathrm{a}+1$, onde os valores negativos indicam que o escore do controle é maior que o da doença e valores positivos significam o oposto. Valores próximos a zero significam praticamente nenhuma diferença entre os escores $\sigma_{C}$ e $\sigma_{D}$.

Ao avaliar diferenças relativas, em princípio pode parecer que um gene $g$ com maior valor absoluto $\Delta(g)$ estaria mais alterado. No entanto, altas intensidades de $X$ tendem a apresentar menores valores absolutos dos escores $|\Delta|$ (menores variações), enquanto baixas intensidades de $X$ apresentam valores muito maiores de $|\Delta|$ (maiores variações). Isto é similar ao problema encontrado na classificação de genes diferencialmente expressos através de MA-plot - em que grandes intensidades de $A$ apresentam menores variações em $M$ (ver Seção 2.1.5). Portanto, para considerar o efeito da intensidade de um dado gene $g$, a ideia seria normalizar o escore de alteração $\Delta(g)$ por sua respectiva intensidade $X(g)$, conforme veremos a seguir.

\section{Escore de alteração normalizado}

Para selecionar os genes mais alterados levando em conta suas intensidades, utilizamos uma função de interpolação semelhante ao método MAID (apresentado na Seção 2.1.5). Primeiro, calculamos os escores de intensidade $X(g)$ e alteração $\Delta(g)$ para cada gene e plotamos um gráfico $X$ versus $\Delta$ - similar ao MA-plot. Em seguida, fazemos uma janela deslizante percorrer o eixo $X$. A janela possui comprimento $w$ e tamanho de deslocamento $s$ pré-definidos. Para uma dada janela definida na posição $x_{i}$ com comprimento $w$, obtemos um conjunto com os valores absolutos $W_{i}=\left\{|\Delta(g)|, \forall g: X(g) \in\left[x_{i}-w / 2, x_{i}+w / 2\right)\right\}-$ pontos cujas intensidades pertencem ao intervalo definido pela janela. Em seguida, para este conjunto $W_{i}$ de valores obtemos o $P_{75}\left(W_{i}\right)$ (percentil 75 ou terceiro quartil) formando o ponto $\left(x_{i}, y_{i}\right)$, onde $y_{i}=P_{75}\left(W_{i}\right)$. Este processo é repetido para todas as posições da janela deslizante, obtendo ao final um conjunto de pontos que será utilizado 
como base para ajustar uma função de interpolação. Estes valores podem ser interpolados por uma função exponencial $\left(f(x)=a e^{-b x}\right)$ ou por uma função lei de potência $\left(f(x)=a x^{-k}\right)$. Hecker et al. [2009] utilizaram uma função exponencial para interpolar os pontos obtidos por um processo semelhante (ver Seção 2.1.5). Escolhemos uma função lei de potência, ao invés da exponencial, uma vez que ela decai mais suavemente, permitindo diferenciar melhor pontos com alta intensidade $(X(g))$. Assim, uma vez ajustada a função de interpolação $f(x)$, o escore de alteração normalizado é definido segundo a Equação 3.4.

$$
\Delta^{\prime}(g)=\frac{\Delta(g)}{f(X(g))}=\frac{\sigma_{D}(g)-\sigma_{C}(g)}{X(g) f(X(g))}
$$

Desta forma, valores baixos de intensidade $X$ (que tendem a apresentar maiores variações) serão divididos por um denominador maior, e a medida que $X$ aumenta (e tende a apresentar menores variações) este denominador vai diminuindo para compensar o efeito da variação dependente da intensidade. O sinal de $\Delta^{\prime}(g)$ indica em que condição um dado gene $g$ está mais co-expresso com os genes sementes. Para fins de ranqueamento, consideramos que um gene será melhor ranqueado quanto maior for o valor absoluto $\left|\Delta^{\prime}(g)\right|$ desse escore de alteração normalizado. 


\section{Capítulo 4}

\section{Estudo de caso: Esquizofrenia}

Esquizofrenia é um dos principais transtornos psiquiátricos afetando $\sim 1 \%$ da população mundial (http://omim.org/entry/181500). É comumente considerada como uma doença complexa com múltiplos fatores genéticos e ambientais envolvidos. Entretanto, fatores genéticos impactam substancialmente no risco de desenvolvimento da doença, com herdabilidade estimada de $\sim 80 \%$ [Sullivan et al., 2003].

Jia et al. [2010] desenvolveram uma ferramenta chamada Schizophrenia Gene Resource (SZGR) que integra diferentes bancos de dados de esquizofrenia e apresenta de forma amigável ao usuário ferramentas online para integrar dados e ranquear genes de forma customizável, além de apresentar os dados de forma gráfica. Eles coletaram dados das principais fontes em esquizofrenia, e atualmente possuem os seguintes conjuntos de dados ${ }^{1}$ : estudos de associação, 3 conjuntos de meta-análises de genome-wide linkage scans, meta-análise de estudos de expressão gênica, busca na literatura, genes obtidos por anotações GO e características de rede PPI. Posteriormente, criaram um ranqueamento usando esses conjuntos de dados visando ranquear os genes mais relevantes. Para cada conjunto de dados é definida uma forma de pontuação (por exemplo, na busca na literatura o método conta quantas vezes um nome de gene ocorre em artigos com termos relacionados a esquizofrenia). Em seguida, cada conjunto de dados recebe um peso, atribuído pelo usuário, e a pontuação global de um dado gene é definida através de uma soma ponderada. No entanto, deve-se ter em mente que formas de ranqueamento envolvendo a literatura geralmente apresentam um viés privilegiando os genes mais estudados.

Um dos problemas que encontramos na integração de genes oriundos de diferentes estudos, é que a interseção entre as listas produzidas é pequena. O trabalho de Jia et al. [2010] pode ilustrar a dificuldade de replicar os resultados (genes encontrados relevantes à uma dada doença complexa) em diversos estudos, seja através de expressão gênica ou de estudos de associação, bem como a dificuldade de integrar dados para priorizar genes mais relacionados à doença. Eles verificaram que vários trabalhos anteriores encontraram genes relacionados à esquizofrenia, mas a interseção entre os conjuntos de genes encontrados nos diversos trabalhos era muito pequena. Por exemplo, a interseção de genes oriundos da análise de transcritoma e genes provenientes de estudos genômicos de associação foi praticamente nula.

\footnotetext{
${ }^{1}$ Utilizamos os resultados de meta-análises de dados de expressão gênica e redes PPI para preencher as duas listas de genes iniciais em nosso trabalho.
} 
Neste trabalho, para avaliar o método proposto adotamos a esquizofrenia como estudo de caso, e esta avaliação concentra-se em três aspectos: obtenção dos genes já conhecidos na literatura, descoberta de novos genes (gene discovering), e aumento da replicação dos estudos.

\subsection{Materiais utilizados nos experimentos}

\subsubsection{Origem dos dados da Rede PPI}

Neste trabalho, a rede PPI utilizada foi composta por 3 bancos de dados de PPI (disponíveis gratuitamente), formando uma única rede PPI final (que representa a união de todos as proteínas e interações dos 3 bancos).

\section{- HPRD $^{1}$ (Human Protein Reference Database)}

Base de dados curada de informações proteômicas referentes à maioria das proteínas humanas. Resultante de um esforço colaborativo internacional do Instituto de Bioinformática de Bangalore - Índia e o Pandey lab na Universidade de Johns Hopkins em Baltimore - EUA.

\section{- MINT $^{2}$ (Molecular INTeraction database)}

Base de dados de interações proteína-proteína verificadas experimentalmente e mineradas a partir da literatura científica por especialistas.

- IntAct ${ }^{3}$ (IntAct molecular interaction database)

Base de dados e ferramentas de análise para interação moleculares de dados. Todas as interações são derivadas da literatura ou submissões diretas de usuário.

\subsubsection{Origem dos Dados de Expressão}

O Stanley Neuropathology Consortium Integrative Database (SNCID) ${ }^{4}$ [Kim \& Webster, 2010] é um banco de dados integrativo, que foi desenvolvido para facilitar a pesquisa psiquiátrica. Ele inclui 1749 marcadores neuropatológicos medidos em 12 regiões diferentes do cérebro de 60 seres humanos (15 de cada: esquizofrenia, transtorno bipolar, depressão, e controles não afetados). Também estão incluídos conjuntos de dados de expressão de microarranjos do genoma inteiro de três estudos independentes.

O compartilhamento de dados usando um banco de dados online é particularmente essencial em estudos psiquiátricos com tecidos post mortem humanos por causa da disponibilidade limitada de amostra. O Instituto de Pesquisa Médica Stanley (SMRI - Stanley Medical Research Institute) tem apoiado estudos psiquiátricos, fornecendo tecido post mortem humano e tem recolhido dados da pesquisa obtidos a partir dessas amostras desde 1995.

O consórcio de neuropatologia Stanley (SNC - Stanley Neuropathology Consortium), a primeira coleção de amostra preparada e distribuída, inclui 15 casos bem acompanhados em cada um dos quatro grupos: esquizofrenia, transtorno bipolar, depressão, e controles não afetados. Além

\footnotetext{
${ }^{1}$ HPRD (http: //www .hprd.org/)

${ }^{2}$ MINT (http://mint.bio.uniroma2.it/)

${ }^{3}$ IntAct (http://www. ebi . ac.uk/intact/)

${ }^{4}$ (http://sncid.stanleyresearch.org)
} 
disso, as amostras de SNC foram usadas em seis estudos independentes de microarranjos de expressão. Os grupos de diagnóstico no SNC são acompanhados por variáveis descritivas tais como idade, sexo, raça, intervalo pós-morte (PMI), a qualidade do mRNA, pH cerebral, e hemisfério.

Os dados de expressão gênica utilizados neste trabalho foram obtidos do SNCID. Foram utilizados 3 estudos e cada um possui dados de expressão gênica de amostras de pacientes com esquizofrenia (doentes) e amostras de indivíduos não afetados (controles). Os estudos utilizados foram:

- KATO (35 controles e 34 doentes);

- BAHN (33 controles e 34 doentes).

- ALTARC (29 controles e 21 doentes);

A normalização desses dados foi realizada pelo pacote da Affymetrix usando o método RMA (Robust Multiarray Average) [Bolstad et al., 2003; Irizarry et al., 2003] na linguagem R. Após a normalização, em casos onde havia diversos transcritos mapeados para o mesmo gene, utilizou-se a mediana para representar a expressão do respectivo gene.

\subsubsection{Conjunto de Genes Sementes}

Para o conjunto de genes sementes $(S)$, utilizou-se um grupo de 38 genes chamados de "core genes" de um banco de dados de esquizofrenia de Jia et al. [2010]. Este conjunto é constituído por genes que apresentaram resultados significativos de meta-análises vindo de estudos de associação.

\subsubsection{Materiais para Integração da Rede PPI e Dados de Expressão}

O mapeamento das proteínas da rede PPI para seus respectivos genes foi realizado através da tabela disponível no $\mathrm{NCBI}^{1}$. Para mapear transcritos (dados de expressão) em seus respectivos genes originais, foi utilizada uma tabela de mapeamento de símbolos presente em uma biblioteca ('hgu133a.db') do conjunto de pacotes Bioconductor ${ }^{2}$, disponível para linguagem R.

Após a integração da rede PPI com dados de expressão, obteve-se uma rede PPI resultante com 9.554 nós (genes) e 61.998 arestas (interações). Dos 38 genes do conjunto de sementes $S$, 30 estavam representados na rede PPI. A esse conjunto $S$ de genes, aplicou-se algumas hipóteses biológicas ('localidade' e 'módulo de doença') para explorar sua vizinhança (ver Seção 3.3). O conjunto $S \cup N$, composto pelos genes sementes $S$ e seus vizinhos diretos $N$ na rede PPI continha 781 genes, resultando em um total de $30 \times 781=23.430$ pares de genes.

\subsubsection{Ferramentas para análise dos genes selecionados}

Para a análise dos genes selecionados, utilizamos algumas ferramentas disponibilizadas pelo site Webgestalt (WEB-based GEne SeT AnaLysis Toolkit) ${ }^{3}$. Deste site, destacamos as ferramentas

\footnotetext{
${ }^{1}$ NCBI gene info (ftp://ftp.ncbi.nih.gov/gene/DATA/GENE_INFO/Mammalia/Homo_sapiens.gene_ info.gz)

${ }^{2}$ Bioconductor open source software for bioinformatics (http://www . bioconductor .org/)

${ }^{3}$ (http://bioinfo. vanderbilt. edu/webgestalt/).
} 
existentes para análise dos bancos de dados GO (Gene Ontology), KEGG (Kyoto Encyclopedia of Genes and Genomes), e para análise de genes relacionados à doença. Basicamente, o projeto $G O$ busca manter um vocabulário controlado dos genes e de seus produtos, provendo uma ontologia de termos definidos para representar as propriedades dos produtos dos genes. Essa ontologia abrange 3 domínios: componente celular, função molecular e processos biológicos. Em nosso caso, ao usarmos a ferramenta $G O$ estamos interessados principalmente em analisar os processos biológicos de um dado grupo de genes. Já o projeto KEGG é um conjunto de banco de dados que possui informações sobre vias biológicas, genomas, doenças, drogas e substâncias químicas. Em nosso caso, ao usarmos a ferramenta KEGG, estamos interessados em analisar as vias biológicas e as doenças associadas a um dado conjunto de genes. Desta forma, realizamos a análise funcional dos genes obtidos, a análise das vias hiper-representadas, e a análise de associação dos genes a doenças. 


\section{Capítulo 5}

\section{Resultados}

Este capítulo apresenta os resultados da aplicação da abordagem integrativa proposta. Utilizamos como entrada dados de: rede PPI, expressão gênica e genes sementes associados a uma doença (estudo de caso: esquizofrenia). Os perfis de expressão gênica foram obtidos a partir de duas condições: controle e doença, e foram atribuídos aos nós da rede (genes) de acordo com os bancos de dados adotados.

Na primeira seção deste capítulo, realizamos uma análise topológica da rede PPI integrada, obtida a partir da integração de três bancos de PPI humano (HPRD, Mint, IntAct) com a integração de dados de expressão gênica (lâmina HGU133a.db). Também é apresentada a distribuição dos caminhos mínimos por pares de genes.

Na segunda seção, discutimos a influência de alguns parâmetros na análise diferencial da rede obtida após a aplicação do cálculo de importância relativa na rede PPI integrada. São apresentados os escores $X$ e $\Delta^{\prime}$ obtidos para cada gene durante a seleção de caminhos. Também são mostrados os resultados da seleção de $10 \%$ dos genes com escores mais alterados. Discutimos a forma utilizada para seleção dos caminhos mínimos e como lidar com possíveis empates relativos à pontuação dos caminhos mínimos para evitar perder informação relevante.

$\mathrm{Na}$ terceira seção, comparamos os ranqueamentos dos genes obtidos pelos escores $X$ e $\Delta^{\prime}$ com os métodos DADA e RWR variando o número de genes obtidos. Posteriormente, comparamos também estes métodos em relação ao ranqueamento gerado pelo grau de cada gene.

Na quarta seção, analisamos a replicabilidade dos resultados obtidos para três bancos de dados de expressão gênica de esquizofrenia (KATO, ALTARC e BAHN), e em seguida é realizada uma análise comparativa do método proposto com os métodos DADA e RWR (Random-Walk with Restart).

\subsection{Análise Topológica da Rede PPI Integrada}

O método proposto utilizou a integração de dados (ver Seção 3.2) provenientes de rede PPI humana, dados de expressão e um conjunto de genes associados à doença. A rede PPI utilizada foi obtida a partir da composição de 3 bancos de dados: HPRD, MINT e IntAct. Os dados de expressão gênica utilizados neste trabalho foram obtidos de alguns estudos (KATO, ALTARC e BAHN) disponíveis no banco de dados SNCID [Kim \& Webster, 2010] - a integração de dados e as análises 
foram feitas separadamente para cada estudo a fim de avaliar a replicabilidade do método.

Conforme mostrado na Seção 3.3.1, diversos trabalhos utilizaram o algoritmo do caminho mínimo para inferir genes relacionados à doença. Para um dado par de genes da rede PPI, é possível haver muitos caminhos mínimos, e alguns destes caminhos serem mais relevantes que outros - a partir da perspectiva biológica. No entanto, os algoritmos de caminho mínimo disponibilizados pelas bibliotecas das linguagens de programação, muitas vezes retornam arbitrariamente um, dentre os diversos caminhos mínimos possíveis entre um par de nós.

Neste trabalho, utilizamos um conjunto $S$ (ver Seção 4.1.3) contendo 30 genes sementes $(|S|=$ 30) e um conjunto $(S \cup N)$ contendo 781 genes $(|S \cup N|=781)$, o que resulta em um total de $|S \times(S \cup N)|=23.430$ pares de genes - cujos caminhos mínimos entre eles serão explorados. A Figura 5.1 mostra a distribuição do número de pares de genes $(S \times(S \cup N))$ - em função do número de caminhos mínimos possíveis.

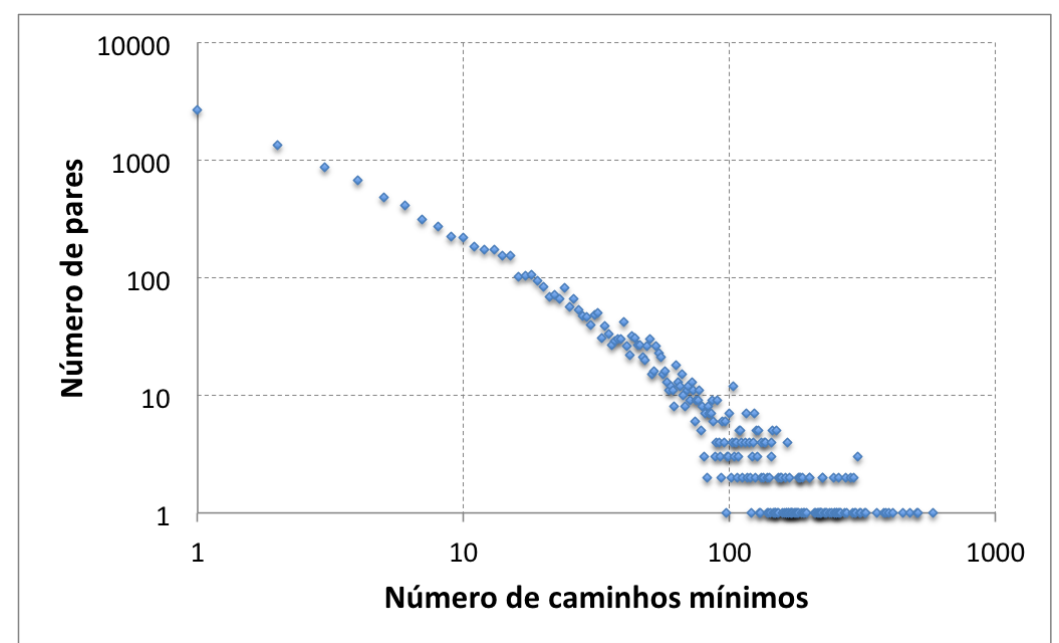

Figura 5.1: Distribuição do número de pares de genes em função do número de caminhos mínimos possíveis (o gráfico está em escala log-log).

É possível notar que vários pares apresentaram mais de 100 caminhos possíveis. É digno de nota que estes 23.430 pares de genes possuem um total de $\mathbf{3 1 6 . 1 3 3}$ caminhos mínimos possíveis entre eles, resultando em uma média de aproximadamente 316.133/24.430 = 13, 5 caminhos mínimos por par de genes. A distribuição de caminhos apresentou desvio-padrão de 26,7 e mediana igual a 4. De fato, muitos pares apresentaram mais que 100 caminhos mínimos possíveis, dentre os quais 587 foi o maior número de caminhos mínimos possíveis para um dado par de genes. Consequentemente, não existe garantia de que um caminho mínimo aleatoriamente escolhido contenha os genes mais relevantes biologicamente. Assim, é possível que alguns caminhos sejam muito mais valiosos que outros a partir da perspectiva biológica. Vários pares de genes possuírem grande quantidade de caminhos possíveis pode ser um indicador da necessidade de se pesquisar novas metodologias para seleção dos caminhos mais relevantes, e que contenham os genes mais relacionados com à doença complexa em questão. Portanto, é importante desenvolver alguma métrica que priorize os caminhos mais significativos em termos biológicos. Com relação aos tamanhos, os caminhos mínimos analisados para este conjunto semente $S$ apresentaram distância média igual a $\mathbf{3 , 0 0 4}$, mediana igual a 3 , variância aproximadamente igual a $\mathbf{0 , 7 5 4}$; e comprimento máximo igual a 6 para um dado par. 


\subsection{Análise diferencial da rede PPI}

Nesta seção são apresentados os resultados referentes as características extraídas a partir da seleção dos caminhos mínimos na vizinhança dos genes sementes segundo uma métrica proposta, que considera aspectos topológicos e de expressão gênica visando encontrar regiões da PPI integrada que estejam mais co-expressas com os genes sementes. Esse processo é realizado em duas condições isoladamente (controle e doença), após o qual são extraídas duas características $\left(\sigma_{C}, \sigma_{D}\right)$ para cada gene. São apresentados os resultados da aplicação do método ao estudo KATO - embora posteriormente tenham sido utilizados também os estudos ALTARC e BAHN, para os quais foram obtidos resultados similares.

\subsubsection{Configuração dos Parâmetros}

O método proposto em sua maior parte não necessita da definição de parâmetros. Mas a partir da etapa de análise diferencial da rede PPI, alguns parâmetros precisam ser definidos. A Tabela 5.1 apresenta a lista dos parâmetros a serem definidos e os valores que adotamos nos experimentos.

\begin{tabular}{|c|r|l|}
\hline Parâmetro & Valores & Descrição \\
\hline \hline percentual & $\{5 \%, 10 \%\}$ & $\begin{array}{l}\text { Define a quantidade percentual de seleção de genes mais alterados } \\
\text { que se deseja encontrar. }\end{array}$ \\
\hline window & 2 & $\begin{array}{l}\text { Tamanho da janela deslizante. Valor utilizado para definir um in- } \\
\text { tervalo em que serão considerados os pontos válidos para cálculo } \\
\text { do IQR (intervalo interquartil) durante a passagem da janela des- } \\
\text { lizante. }\end{array}$ \\
\hline slide & $\{2,5\}$ & $\begin{array}{l}\text { Deslocamento da janela deslizante. Utilizado o valor padrão 1. } \\
\text { Dão considerados, desconsiderando pontos abaixo deste valor (fil- } \\
\text { tragem de pontos com escores } X \text { muito baixos }- \text { potencialmente } \\
\text { ruídos). }\end{array}$ \\
\hline$x_{\text {ini }}$ & $\{.05, .10, .20, .40\}$ & $\begin{array}{l}\text { Fator utilizado para tratamento de empates. Usualmente deve ser } \\
\text { mantido pequeno. }\end{array}$ \\
\hline
\end{tabular}

Tabela 5.1: Lista de parâmetros utilizados.

O parâmetro percentual deve ser definido pelo usuário, de acordo com a quantidade pretendida de genes que se deseja obter. $\mathrm{O}$ window (tamanho da janela) causou pequena variação na curva ajustada para valores menores que 10 , com o parâmetro slide definido como metade do seu valor $($ window/2) ; então usamos os valores nominais window $=2$ e slide $=1$ como padrão. $\mathrm{O}$ parâmetro $X_{\text {ini }}$ foi usado para filtrar pontos com intensidades $X$ muito pequenas. O parâmetro $\epsilon$ foi utilizado para tratamento de empates, ou seja, se a diferença entre a pontuação de dois caminhos for menor que $\epsilon$, então eles serão considerados empatados. Variamos significativamente este parâmetro $(\epsilon=\{0.05,0.10,0.20,0.40\})$ apenas para avaliar seu impacto na seleção dos caminhos e estudar seu comportamento, mas recomenda-se que valores pequenos ( $\epsilon \leq 0.05$, por exemplo) sejam utilizados. 


\subsubsection{Estudo da Variação dos Parâmetros}

Nesta subseção são apresentados os resultados da extração de características após uma transformação que permite uma visualização similar ao MA-plot. É apresentado o resultado para seleção de 1 único caminho e em seguida, apresenta-se os resultados para seleção de múltiplos caminhos - parâmetro $\epsilon$ para tratamento de empates. É feita uma análise da variação do parâmetro $\epsilon$ e como este influencia os resultados da seleção dos caminhos.

\section{Transformação similar ao MA-plot}

Conforme comentado na Seção 3.4, um problema que se tem ao selecionar genes diferencialmente expressos usando o gráfico MA-plot é que regiões de baixas intensidades ( $A$ pequeno) tendem apresentar grandes variações de $M$, enquanto que regiões com altas intensidades apresentam menores variações. Em nosso método, observamos um comportamento semelhante ao MA-plot após aplicarmos as transformações de intensidade $X=\sigma_{C}+\sigma_{D}$ (eixo horizontal) e escore de alteração $\Delta=\left(\sigma_{D}-\sigma_{C}\right) /\left(\sigma_{C}+\sigma_{D}\right)$ (eixo vertical). Observe, como exemplo, a Figura 5.2-(a) que apresenta um gráfico com a distribuição dos pontos após essas transformações ${ }^{1}$. É digno de nota que pontos de baixa intensidade $X$ tendem a apresentar maiores escores de alteração $\Delta$ e estes tendem a diminuir a medida que a intensidade $X$ aumenta. Também é possível observar que a maior concentração de pontos acontece para baixos valores de intensidade $(X<100)$ e, a medida que a intensidade aumenta, a concentração de pontos diminui. Na verdade, uma análise mais detalhada nos mostrou que a grande maioria ${ }^{2}$ dos pontos está concentrada para $X \leq 10$, e que nesta região muitos pontos estão com valores de $\Delta$ iguais a -1 ou 1 , indicando que participaram apenas de uma das condições (controle ou doença), mas não de ambas.

\section{Variação do parâmetro $\epsilon$}

O parâmetro $\epsilon$ é utilizado para tratamento de múltiplos caminhos que estejam praticamente empatados por uma pequena diferença. É um fator que, ao ser multiplicado pelo peso do melhor caminho, estabelece a diferença máxima que será considerada empate (a partir do escore do melhor caminho mínimo). Na prática, se $\epsilon=0$ será equivalente a selecionarmos somente 1 caminho mínimo por par. Para que todos os pares contribuam uniformemente no escore global de cada gene, em casos de empates para um dado par de genes, o peso de cada caminho empatado é dividido pelo número de caminhos empatados. Para avaliar seu impacto na seleção de caminhos este parâmetro foi variado em diversos valores $(\epsilon=\{0.00,0.05,0.10,0.20,0.40\})$.

Lembrando que o total de caminhos avaliados foi de 316.133, para um total de 23.430 pares de genes. A Tabela 5.2 apresenta os valores médios e percentuais de caminhos selecionados por par de genes, para os diferentes valores de $\epsilon$. Para facilitar a comparação, é apresentado na primeira linha da tabela o valor total (e percentual) de caminhos selecionados para seleção de 1 único caminho por par. Esses valores referem-se aos dados de expressão do estudo KATO - os demais estudos (ALTAR e BAHN) apresentaram números de caminhos muito próximos. Observa-se nesta tabela que a seleção de 1 único caminho por par apresentou 7,4\% do total de caminhos mínimos possíveis,

\footnotetext{
${ }^{1}$ Foram utilizados dados de expressão do estudo KATO.

${ }^{2}$ Conforme será apresentado na Tabela $5.3,90 \%$ dos pontos concentram-se em $X=\left(\sigma_{C}+\sigma_{D}\right) \leq 10$.
} 


\begin{tabular}{|r|r|r|}
\hline$\epsilon$ & Média por par & \% por par \\
\hline \hline 0,00 & 1,000 & $7,4 \%$ \\
\hline 0,05 & 1,690 & $12,5 \%$ \\
\hline 0,10 & 2,767 & $20,5 \%$ \\
\hline 0,20 & 5,930 & $43,9 \%$ \\
\hline 0,40 & 12,655 & $93,8 \%$ \\
\hline
\end{tabular}

Tabela 5.2: Valores médios e percentuais de caminhos selecionados por par de genes, para os diferentes valores de $\epsilon$.

o que corresponde a 23.430 caminhos selecionados (1 por par). Ao utilizarmos o parâmetro $\epsilon=$ 0.05 como critério de desempate o percentual de caminhos selecionados aumentou para 12,5\% (resultando em uma média de 1,69 caminhos por par). A medida que $\epsilon$ aumenta, o percentual de caminhos selecionados aumenta consideravelmente. É interessante destacar que para $\epsilon=0,40$ são selecionados praticamente todos os caminhos possíveis (93,8\% dos 316.133). Isto indica que este valor deve ser mantido baixo, caso contrário perderá o sentido de ser usado como critério de desempate.

O impacto da variação do parâmetro $\epsilon$ - após as transformações similares ao MA-plot - é apresentado na Figura 5.2 - os bancos ALTAR e BAHN produziram resultados similares. Conforme esperado, é possível observar que valores pequenos de $\epsilon$ apresentam pontos mais destacados por aspectos de expressão e/ou topológicos. Mas a medida que se aumenta o valor de $\epsilon$ mais aglomerados ficam os pontos, reduzindo o efeito que aspectos de expressão e/ou topológicos poderiam ter sobre alguns pontos de destaque. Assim, conforme já mencionado, recomenda-se que o valor do parâmetro $\epsilon$ seja baixo para que este desempenhe apenas o papel de tratamento de empates, sem reduzir o efeito de pontos biologicamente importantes. Daqui em diante, utilizaremos o valor $\epsilon=0.05$ em nossas análises por considerarmos que este valor atende esses requisitos.

\section{Variação do parâmetro $X_{i n i}$}

Conforme pode ser visto na Figura 5.2, a dispersão dos pontos $X=\left(\sigma_{C}+\sigma_{D}\right)$ versus $\Delta=\left(\sigma_{D}-\right.$ $\left.\sigma_{C}\right) /\left(\sigma_{C}+\sigma_{D}\right)$ apresenta uma grande concentração de pontos com baixos valores de $X$ (menores que 20) e poucos pontos com valores consideravelmente altos de $X$ (acima de 100). Lembrando que genes com valores altos de $X$ apresentam desejáveis aspectos topológicos e de expressão, pois pertencem a caminhos co-expressos com as sementes e ao mesmo tempo estão próximos de várias sementes na rede PPI. Por outro lado, genes com valores muito baixos de $X$ pertencem a caminhos pouco co-expressos com as sementes (que raramente participaram dos caminhos selecionados) e/ou que estão distantes da maioria das sementes na rede PPI. Desta forma, do ponto de vista biológico pode ser interessante filtrar casos de genes com $X$ muito baixos. O parâmetro $X_{\text {ini }}$ indica a partir de qual valor mínimo de $X$ os pontos serão considerados ( $X$ suficientemente desejável) - e pontos com $X$ abaixo desse valor serão filtrados.

A Tabela 5.3 mostra a distribuição das intensidades $X$ para os estudos KATO, ALTAR e BAHN - todos com valores de $\epsilon=0,05$. A primeira linha apresenta o total de pontos (ou genes após a 


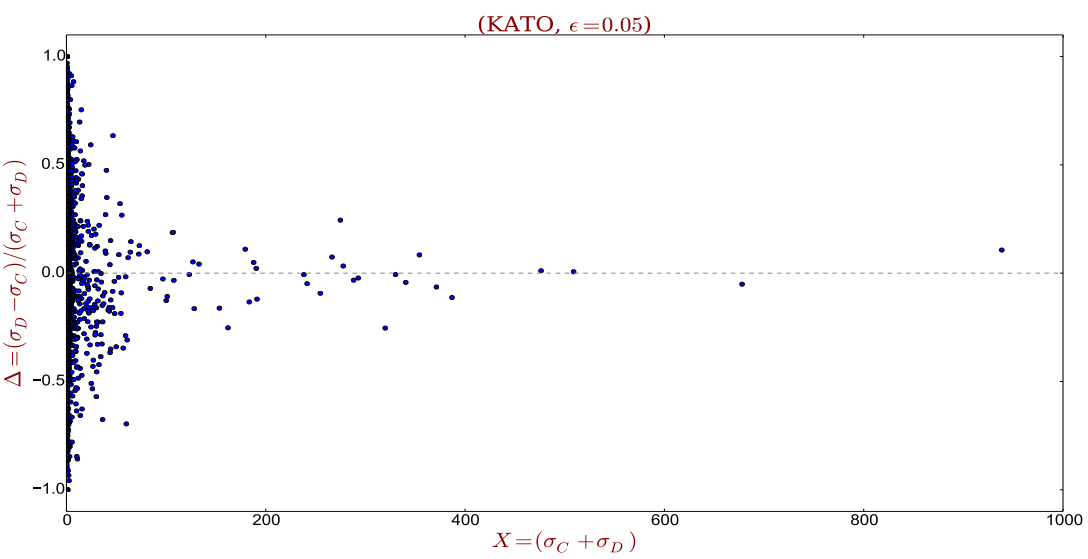

(a)

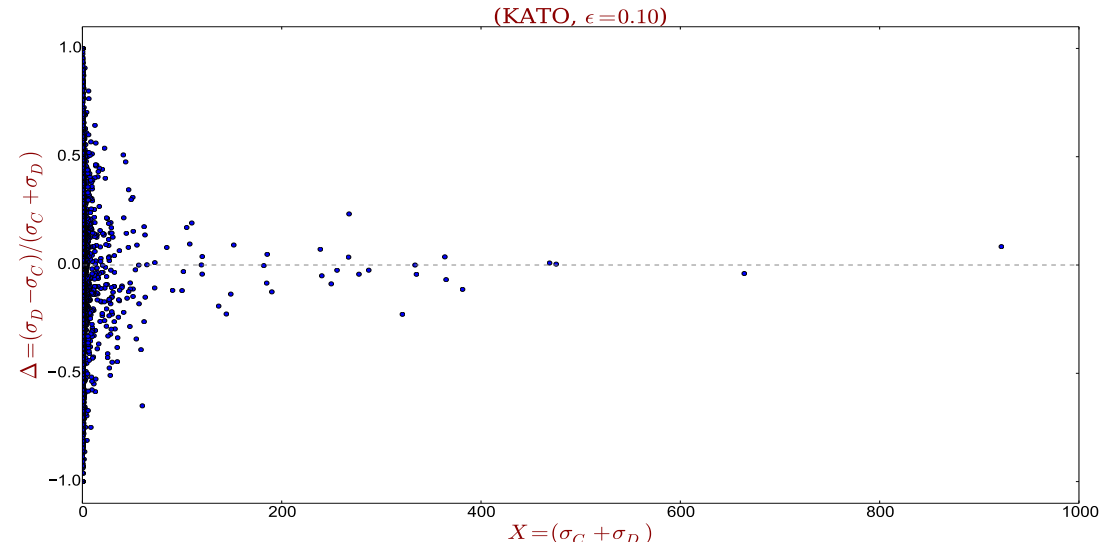

(b)

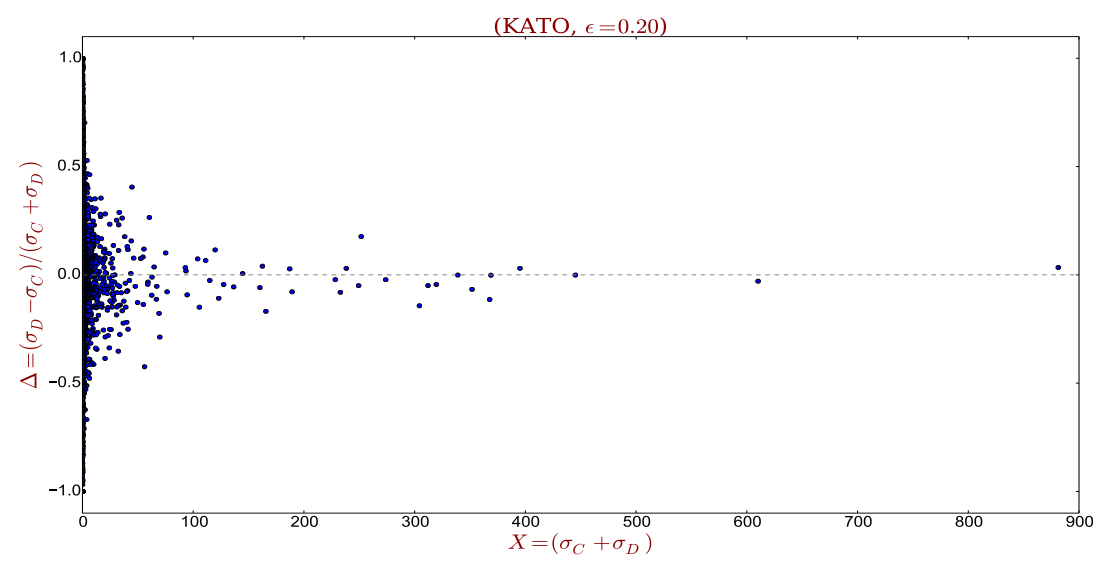

(c)

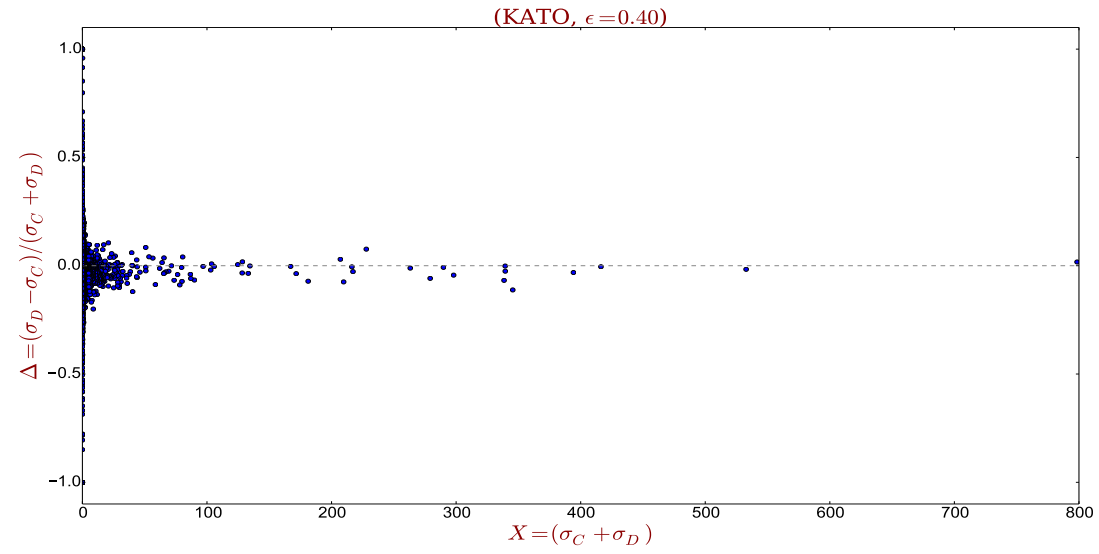

Figura 5.2: Dispersão dos pontos de $X=\left(\sigma_{C}+\sigma_{D}\right)$ versus $\Delta=\left(\sigma_{D}-\sigma_{C}\right) /\left(\sigma_{C}+\sigma_{D}\right)$ para $o$ estudo KATO e com valores de $\epsilon=\{0.05,0.10,0.20,0.40\}$. 


\begin{tabular}{|r|r|r|r|}
\hline & $\begin{array}{r}\text { KATO } \\
(2646 \text { genes })\end{array}$ & $\begin{array}{r}\text { ALTAR } \\
(2836 \text { genes })\end{array}$ & $\begin{array}{r}\text { BAHN } \\
(2764 \text { genes })\end{array}$ \\
\hline$X$ mínimo & 0.0035 & 0.0045 & 0.0044 \\
$1^{\text {o }}$ quartil $(25 \%)$ & 0.0988 & 0.0969 & 0.0833 \\
Mediana (50\%) & 0.346 & 0.333 & 0.307 \\
$3^{\text {o }}$ quartil (75\%) & 1.50 & 1.35 & 1.40 \\
Percentil 80\% & 2.14 & 2.08 & 2.06 \\
Percentil 85\% & 3.70 & 3.71 & 3.55 \\
Percentil 90\% & 6.94 & 7.20 & 6.48 \\
Percentil 95\% & 20.93 & 18.20 & 17.72 \\
$X$ máximo & 938.5 & 868.5 & 685.9 \\
\hline Média $(\bar{X})$ & $\mathbf{6 . 1 9}$ & $\mathbf{5 . 8 9}$ & $\mathbf{5 . 6 0}$ \\
Desvio Padrão & $\mathbf{3 6 . 8}$ & $\mathbf{3 4 . 9}$ & $\mathbf{3 2 . 3}$ \\
\hline
\end{tabular}

Tabela 5.3: Algumas medidas (Mínimos, Máximos, Quartis, Percentis, Média e DesvioPadrão) da distribuição de $X(\epsilon=0.05)$ para os estudos KATO, ALTAR e BAHN.

extração de características) para cada estudo - variando de 2646 a 2836 - que é um número relativamente alto de genes, apesar de já ter havido uma redução do número inicial - aproximadamente 10 mil. Em seguida, são apresentados (para $X$ ) a média, o desvio padrão, os valores mínimo, máximo e alguns percentis. Nos 3 estudos a média ficou próxima de 6, a mediana (percentil 50\%) ficou um pouco acima de 0.3, e o terceiro quartil (percentil 75\%) ficou em torno de 1.50 - indicando uma alta concentração de pontos para valores muito baixos de $X$. Além disso, é possível notar que a grande maioria (aproximadamente 90\%) dos pontos encontra-se abaixo de 7, apesar dos valores máximos para cada estudo serem altos (variando de 685.9 a 938.5).

A Figura 5.3 apresenta o detalhamento dos pontos iniciais com valores de $X$ entre 0 e 10 . É possível observar que muitos pontos desse intervalo possuem valores iguais a -1 ou 1 - sugerindo que seus respectivos genes raramente participaram dos caminhos selecionados e, quando isso ocorreu, foi apenas em uma das condições (controle ou doença). $O$ fato desses genes participarem de poucos caminhos selecionados deve-se a baixa co-expressão com as sementes ou a estarem distantes das sementes, resultando em baixos valores de $X$. Devido a isso, é desejável filtrá-los para analisar somente pontos com características potencialmente relevantes.

Visto que o método prioriza genes com aspectos topológicos e de expressão, estamos interessados em genes que apresentaram valores mínimos de $X$ razoáveis para serem considerados. A maior parte dos pontos (aproximadamente $90 \%$ ) ficou com valores de $X$ muito baixos, e isto indica que o método está filtrando os genes com uma seletividade considerável. No entanto, é importante mencionar que mesmo se considerarmos apenas $10 \%$ dos pontos isto representará um total de 264 a 284 genes, o que ainda constitui números relativamente altos de genes para serem analisados.

Uma vez que a maior concentração dos pontos ocorre para valores de $X$ muito baixos (tipicamente menores que 10 nos três estudos considerados) fixar o parâmetro $X_{i n i}$ serve para realizar uma pré-filtragem em pontos que não possuem às características topológicas e de expressão com valores mínimos desejáveis, deixando passar apenas genes com tais características para serem analisados na etapa seguinte. Na Seção 5.4, analisamos a influência do parâmetro $X_{\text {ini }}$ na replicação dos estudos (KATO, ALTARC e BAHN) e constatamos que o valor $X_{i n i}=5$ apresenta bons re- 
sultados, por selecionar genes com tais características desejáveis. Por esta razão, deste ponto em diante usaremos este valor $\left(X_{i n i}=5\right)$ em nossas análises.

\subsection{Comparação entre os métodos (DADA vs RWR vs $X$ vs $\Delta^{\prime}$ )}

Nesta seção, realizamos uma análise comparativa dos métodos DADA e RWR com os escores $X$ e $\Delta^{\prime}$ resultantes do método proposto ${ }^{1}$. Com essa finalidade em mente, dadas as listas dos $N$ primeiros genes ranqueados por cada método, comparamos quantos genes existem em comum entre elas e o quanto as ordenações dos genes em comum são parecidas. Após essas análises, comparamos também o ranqueamento dos genes pelos seus graus com os ranqueamentos obtidos pelos 4 métodos considerados (DADA, RWR, $X, \Delta^{\prime}$ ). Utilizamos dados de expressão do estudo KATO nas análises apresentadas a seguir, mas resultados bastante similares foram obtidos para os estudos ALTARC e BAHN (resultados não mostrados).

Em ambos os métodos RWR e DADA, utilizamos como sementes a mesma lista de 30 genes sementes utilizada para o método proposto (ver Seção 4.1.3), e a probabilidade de reinício foi configurada para $r=0,3$, já que este foi o valor ótimo obtido nas análises do Erten et al. [2011]. Em particular para o DADA, a configuração padrão de parâmetros do DADA retornou resultados idênticos ao RWR. Devido a isso, utilizamos os parâmetros de ajuste estatístico EIGENVECTOR CENTRALITY e priorização uniforme OPTMISTIC PRIORITIZATION, também considerada por [Erten et al., 2011] uma das melhores configuração de parâmetros para o método DADA. A lista de genes utilizada como candidatos foi toda a rede PPI, mas uma vez obtidos os ranqueamentos (lista de genes priorizada pelos métodos RWR e DADA), selecionamos para as análises comparativas apenas algum percentual dos melhores ranqueados.

No método proposto, é importante ter em mente que selecionar os genes pelo escore $\Delta^{\prime}$ produz uma lista de genes que (além de aspectos topológicos relevantes) possuem as características $\left(\sigma_{C} \mathrm{e}\right.$ $\sigma_{D}$ ) mais alteradas entre as duas condições (controle e doença), ao passo que selecionar genes com

\footnotetext{
${ }^{1}$ Para facilitar a exposição, chamaremos os escores $X$ e $\Delta^{\prime}$ de 'métodos', muito embora eles sejam apenas valores resultantes de um mesmo método.
}

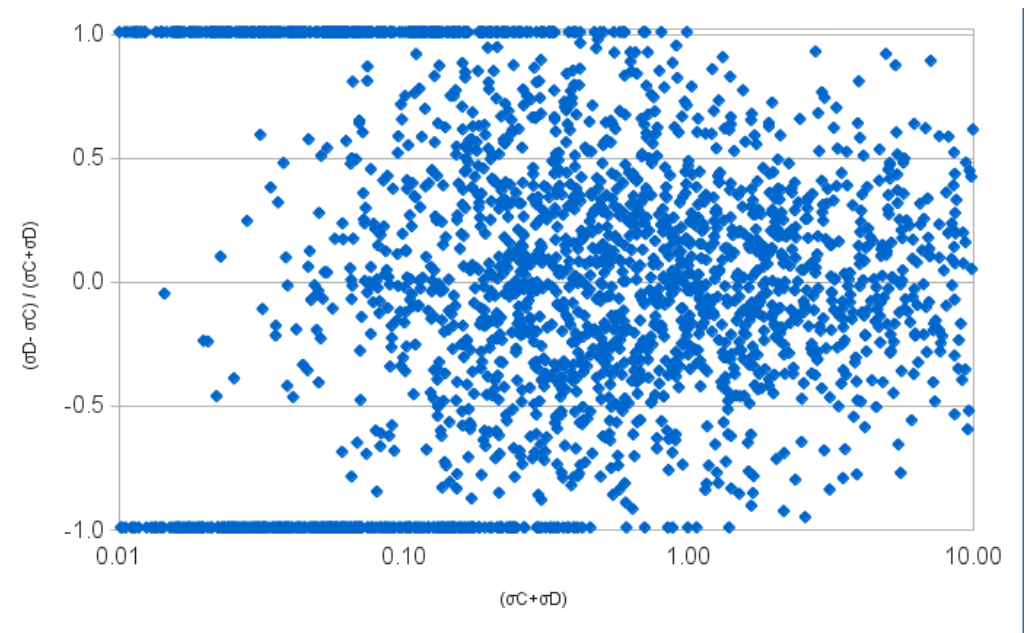

Figura 5.3: Detalhamento dos valores iniciais de X. O eixo X está em escala logarítmica. 
maiores escores $X$ retorna aqueles que possuem valor elevado de uma ou ambas as características. Para selecionar os genes com as características mais alteradas, basta identificar aqueles que foram classificados como alterados segundo suas pontuações diferenciais (Equação 3.4), ou seja, aqueles com os maiores valores de $\Delta^{\prime}$.

A Figura 5.4 ilustra os $5 \%$ genes selecionados como mais alterados (maiores $\Delta^{\prime}$ ) pelo nosso método - o mesmo número de genes foi utilizado para comparação com o método DADA. Os genes identificados como mais alterados (maiores $\Delta^{\prime}$ ) estão representados em vermelho ou verde, indicando que são mais co-expressos na doença ou no controle, respectivamente. Pontos em cinza representam genes que não são considerados alterados entre as duas condições. Genes obtidos pelo método DADA estão representados em azuis. Selecionar 5\% dos genes ranqueados pelo escore $\Delta^{\prime}$ é equivalente a fazer um ajuste nas curvas ajustadas por lei de potência, afastando-as ou aproximando-as do eixo $X$, a fim de que os pontos em seu exterior (vermelhos e verdes) correspondam a $5 \%$ do total de pontos contidos no gráfico.

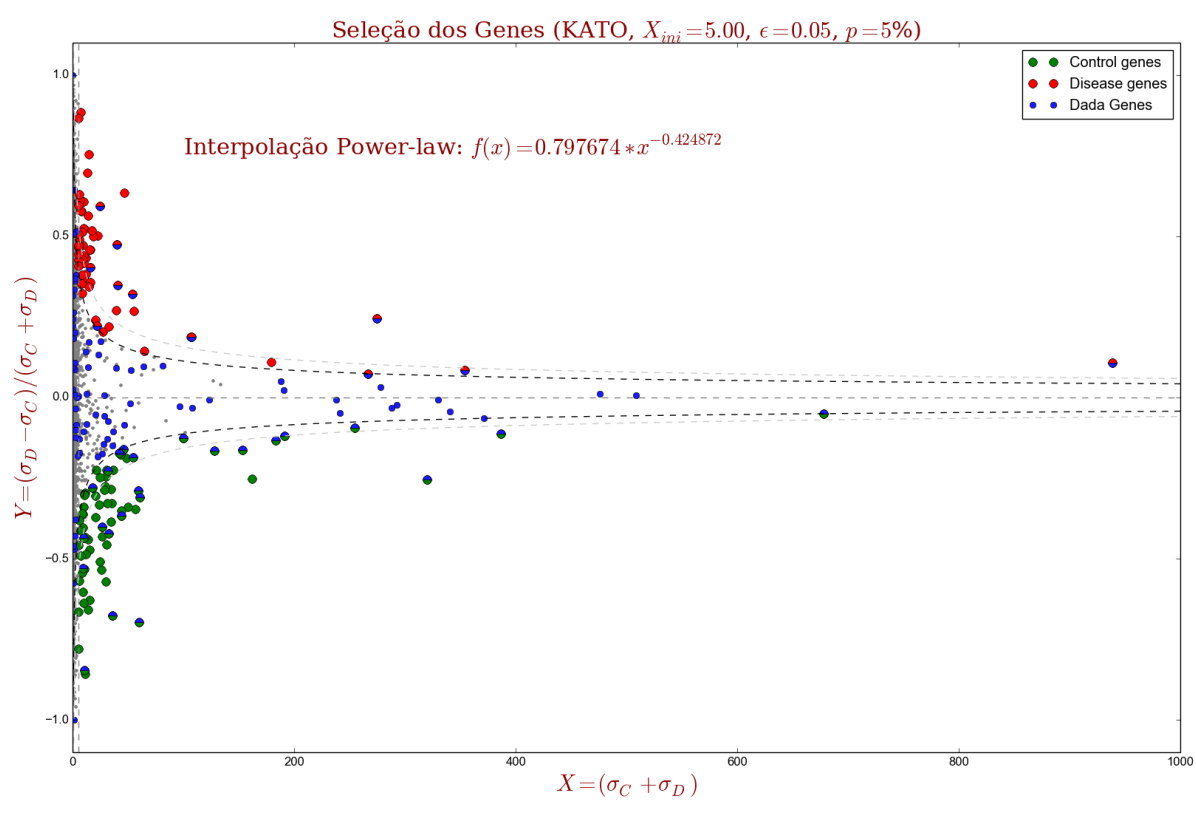

Figura 5.4: Comparação entre 5\% de genes selecionados por $\Delta^{\prime}$ e DADA. O escore $\Delta^{\prime}$ seleciona genes com as características $\sigma_{C}$ e $\sigma_{D}$ mais alteradas, após a aplicação de uma interpolação paramétrica LEI DE POTÊNCIA. Pontos vermelhos e verdes representam genes mais alterados nas redes de controle ou doença, respectivamente. Pontos em cinza representam genes que não são considerados alterados entre as duas condições. Pontos azuis representam genes obtidos pelo método DADA. Genes com valores altos de $X$ participam em muitos caminhos mínimos selecionados, o que significa que têm grande importância topológica em relação aos genes de sementes - tanto na centralidade topológica quanto na concordância de expressão.

Existem algumas diferenças notáveis entre os dois métodos. Por um lado, sabemos que o DADA visa reduzir o problema de viés de apuração, mas, em contrapartida, ele recupera os pontos que não são diferencialmente alterados entre duas condições. Já o nosso método (escore $\Delta^{\prime}$ ) recupera com sucesso genes co-expressos diferencialmente em duas condições, e também evita o 
viés da literatura - é possível ver genes com valores altos de $X$ que não foram selecionados. Deste modo, por integrar mais dados o nosso método consegue fornecer resultados mais específicos de acordo com a co-expressão diferencial do gene (em duas condições). Mais detalhes comparativos entre os métodos serão apresentados nas seções seguintes.

\subsubsection{Interseções e correlações entre os métodos (DADA, RWR, $X, \Delta^{\prime}$ )}

Para compararmos as interseções e correlações entre os ranqueamentos obtidos pelos métodos (DADA, RWR, $X, \Delta^{\prime}$ ), primeiramente selecionamos a lista dos $N$ melhores genes ranqueados por cada método. Em seguida, extraímos a quantidade de genes existentes na interseção entre as listas e avaliamos a correlação de postos Spearman de tais interseções. Variamos a quantidade ( $N$ melhores) dos genes considerados para analisar e discutir a evolução dos perfis de interseção e correlação entre as listas.

A Figura 5.5 apresenta a comparação dos $N$ melhores genes ranqueados por cada método: DADA, RWR, $X$ e $\Delta^{\prime}$, variando $N$ de 20 até 1000. No gráfico superior, são apresentadas as interseções (em proporção) entre os $N$ melhores genes obtidos por cada método. Já o gráfico inferior, apresenta as correlações de postos de Spearman entre os genes obtidos (na interseção) por cada método. É possível observar que, para um número baixo de genes considerados $(N \leq 100)$, a in-
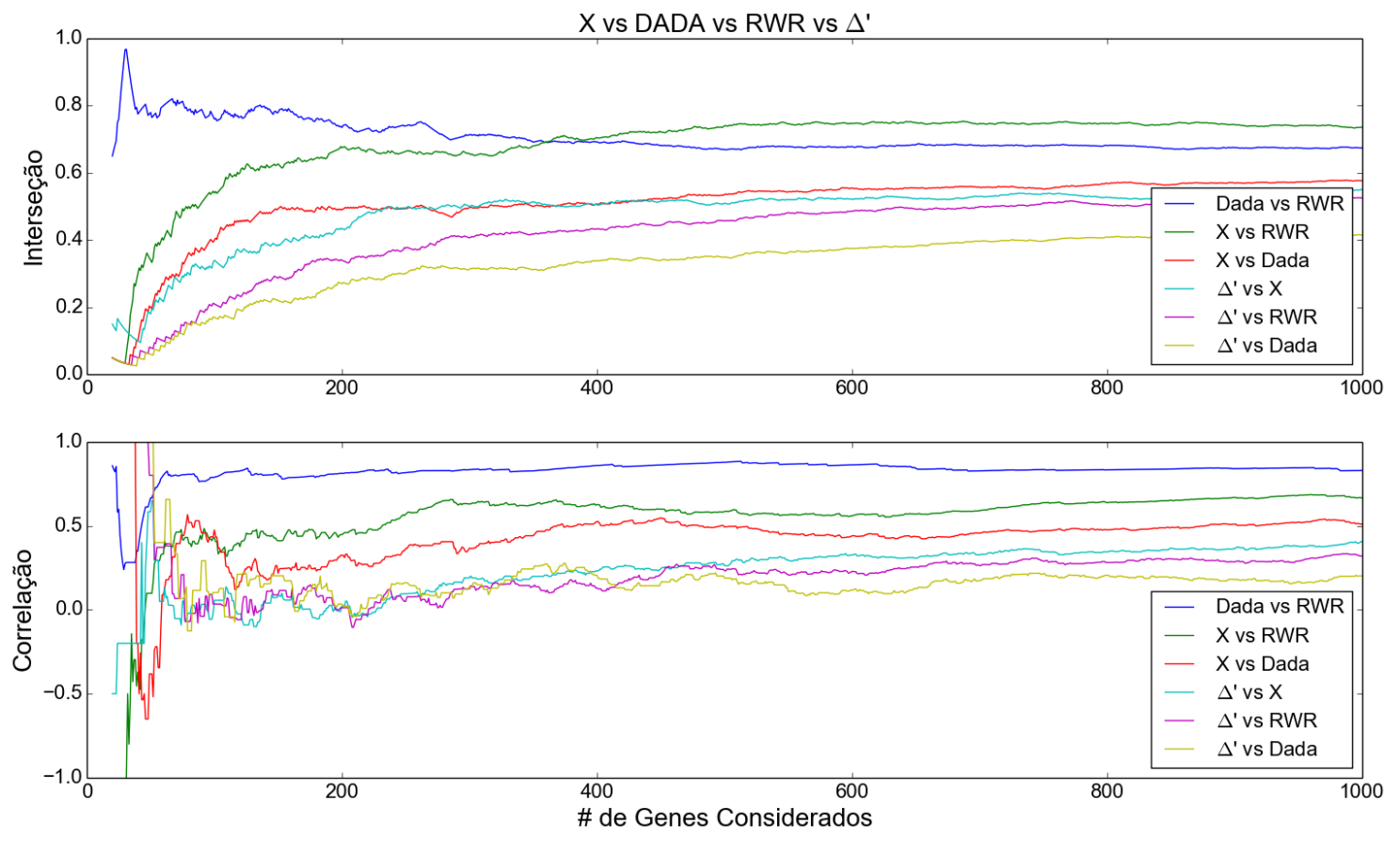

Figura 5.5: Comparação dos genes ranqueados pelos métodos DADA, RWR, $X$ e $\Delta^{\prime}$. Variouse o número de genes considerados (primeiros genes ranqueados por cada método). No gráfico superior, apresenta-se as interseções (em proporção) entre as listas dos primeiros genes obtidos por cada método. No gráfico inferior, apresenta-se as correlações entre os genes obtidos (na interseção) por cada método.

terseção entre os métodos DADA e RWR é destacadamente alta (em torno de 0.8), ao passo que as interseções entre os demais métodos iniciam relativamente baixas e vão crescendo gradativamente a medida que $N$ aumenta. Para esse mesmo domínio considerado $(N \leq 100)$, observa-se grandes 
flutuações nas correlações dos genes pertencentes às interseções entre os métodos. Isto é esperado, pois inicialmente $(N \leq 50)$ a maioria das interseções (exceto entre DADA e RWR) é muito baixa possuindo no máximo 3 genes, o que dificulta o cálculo das correlações entre as listas ${ }^{1}$. A partir de $N \geq 100$, percebe-se em ambos os gráficos (interseção e correlação) que as curvas começam a estabilizar. Embora a interseção entre DADA e RWR seja superada pela interseção entre $X$ e RWR a partir de $N=360$, observa-se que a correlação entre DADA e RWR permanece a maior de todas (em torno de 0.84). Isto é esperado, pois o método DADA é um ajuste estatístico visando intercalar alguns genes relativamente de baixo grau à lista resultante do RWR. Dessa forma, a interseção entre DADA e RWR é alta no início e tende a cair a medida que $N$ aumenta. Já a correlação entre DADA e RWR inicialmente $(N \leq 30)$ é alta, seguida de um declínio no início $(N \in[31,38])$ devido a intercalação de genes inseridos pelo ajuste do DADA, e em seguida volta a crescer, alcançando um patamar em torno de 0,84 .

Quanto às interseções e correlações apresentadas por $X$ e $\Delta^{\prime}$ na Figura 5.5, observa-se que estas são maiores para $X$, que apresentou maiores interseções e correlações com RWR seguido de DADA. As menores interseções e correlações foram apresentadas por $\Delta^{\prime}$ em relação as demais (o que era esperado pois $\Delta^{\prime}$ foi idealizado para capturar as alterações entre controle e doença). A maior interseção de $\Delta^{\prime}$ foi $\operatorname{com} X$ (em torno de 0,53) e a menor foi com DADA (em torno de 0,38). A partir de $N=400$, As correlações de $\Delta^{\prime}$ com os demais métodos foram baixas, ficando em torno de 0,1 com relação ao DADA, em torno de 0,2 com o RWR, e em torno de 0,35 com o $X$. Isto sugere que o $\Delta^{\prime}$, por levar em conta primordialmente as diferenças de co-expressão entre controle e doente, tende a capturar genes novos, não obtidos pelos demais métodos. Quanto ao $X$, embora considere a co-expressão e a localização em relação as sementes como fatores importantes, estas não são consideradas de forma diferencial, resultando em uma correlação moderada com os métodos DADA e RWR.

\subsubsection{Interseções e correlações do Grau vs (DADA, RWR, $X, \Delta^{\prime}$ )}

Conforme visto na Seção 2.2.3, genes conhecidos por estarem associados a doenças tendem a ser altamente conectados (apresentarem alto grau). Esta distorção na distribuição do grau das redes PPI é conhecida como ascertainment bias, e deve-se ao fato de que proteínas altamente estudadas na literatura geralmente possuem mais interações e associações com doenças comparadas com aquelas menos estudadas. Devido a isso, métodos existentes geralmente tendem a privilegiar genes com graus mais altos. Por outro lado, também podem existir genes associados à doença que não foram tão estudados (e por isso tendem a possuir baixos graus), podendo não ser recuperados pelos métodos existentes. Por isso, nesta seção analisaremos as interseções e correlações entre o ranqueamento obtido pelos graus dos genes em relação aos ranqueamentos obtidos pelos demais métodos (DADA, RWR, $X, \Delta^{\prime}$ ).

A Figura 5.6 apresenta uma comparação dos genes ranqueados pelo grau em relação aos genes ranqueados pelos métodos DADA, RWR, $X$ e $\Delta^{\prime}$, variando-se o número $(N)$ dos primeiros

\footnotetext{
${ }^{1}$ Por exemplo, não é possível calcular correlação em listas com apenas 1 elemento, e em listas com apenas 2 é possível obter facilmente correlações de 1 ou -1, que não são representativas. Assim, listas com poucos elementos são suscetíveis a grandes flutuações de correlações, mas a medida que o número de elementos da interseção aumenta esse efeito é reduzido.
} 
genes considerados. Observa-se que, para um número baixo de genes considerados $(N \leq 100)$,
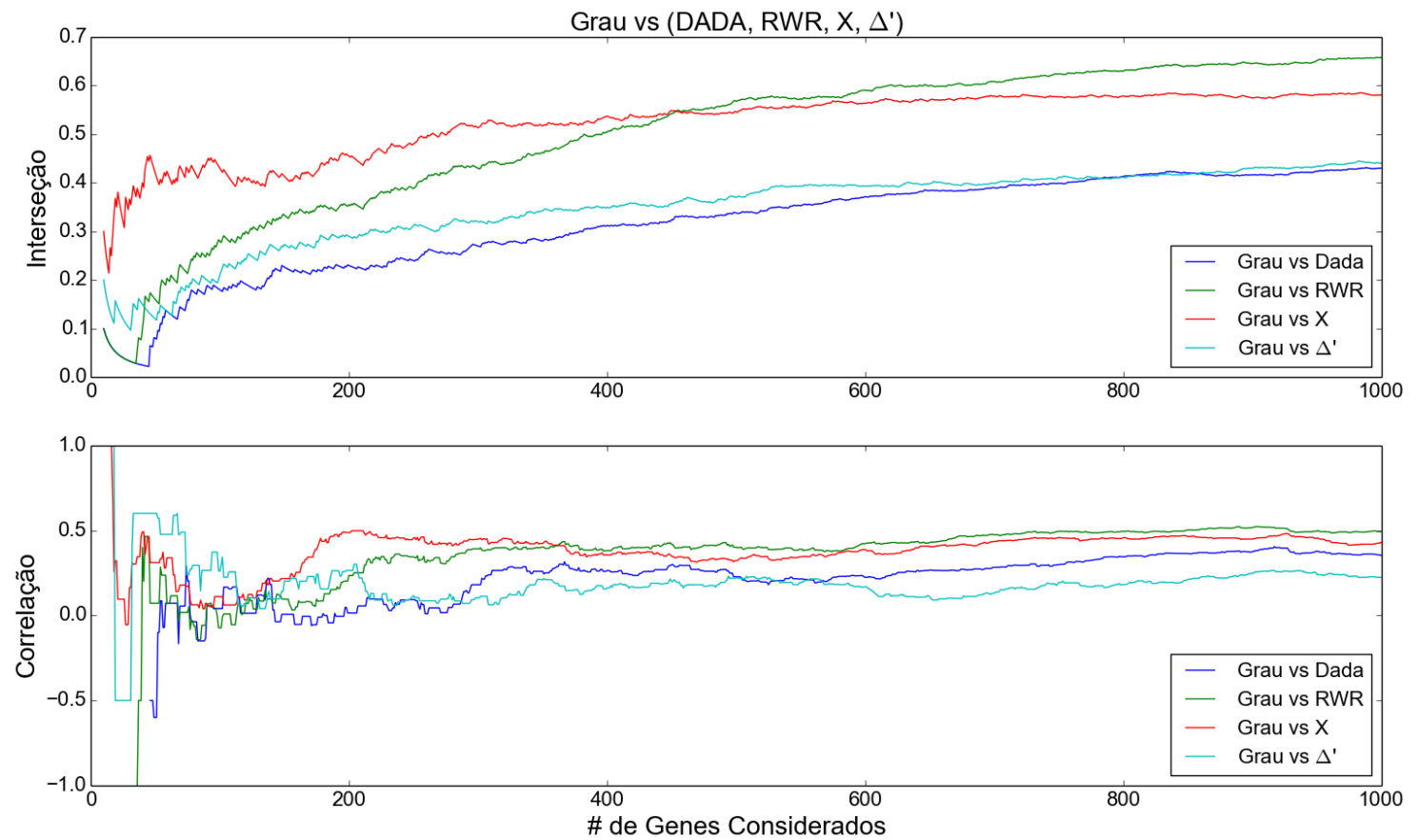

Figura 5.6: Comparação do ranqueamento dos genes pelo Grau em relação aos ranqueamentos dos métodos DADA, RWR, X e $\Delta^{\prime}$. Variou-se o número de genes considerados (primeiros genes ranqueados por cada método). No gráfico superior, apresenta-se as interseções (em proporção) entre as listas dos primeiros genes obtidos pelo grau em relação aos métodos. No gráfico inferior, apresenta-se as correlações entre os genes obtidos (na interseção) pelo grau em relação aos demais métodos.

a interseção entre o Grau e $X$ foi mais alta que os demais (variando entre 0,21 e 0,46), ao passo que as interseções do Grau com os demais métodos iniciam próximas de zero e aumentam gradativamente com o $N$, até atingirem os valores de 0,28, 0,21 e 0,19, respectivamente para RWR, $\Delta^{\prime}$ e DADA. Neste mesmo intervalo, nota-se grandes flutuações nas correlações do ranqueamento do Grau em relação aos ranqueamentos dos métodos, devido ao fato da maioria das interseções serem relativamente baixas. Para $N \geq 200$, percebe-se no gráfico da correlação que as curvas começam a estabilizar apresentando menores flutuações. Percebe-se ainda que interseção (Grau $\cap X$ ) é superada pela interseção (Grau $\cap$ RWR) a partir de $N=450$, o que mostra que o RWR tende a incorporar em sua lista uma proporção maior de genes de alto grau à medida que $N$ aumenta. Os ranqueamentos obtidos pelo escore $\Delta^{\prime}$ e pelo método DADA apresentaram valores relativamente baixos de interseção e de correlação com o Grau ao longo de todo o domínio. Para $N \geq 200$, embora a interseção do $\Delta^{\prime}$ com o Grau tenha sido um pouco maior do que a interseção do DADA com o Grau, a correlação do $\Delta^{\prime}$ com o Grau acabou sendo igual ou ligeiramente menor que a correlação do DADA com o Grau .

É importante lembrar que o escore $X$ busca encontrar genes que estão co-expressos na vizinhança dos genes sementes em uma ou em ambas as condições (controle e/ou doença). No método proposto, apesar da seleção dos caminhos não depender do grau, mas sim da co-expressão dos genes com as sementes, genes de alto grau e altamente co-expressos tenderão a ser priorizados pelo escore $X$, pois isso possibilita que ele participe de vários caminhos mínimos entre os 
genes sementes. Assim, o escore $X$ tenderá a obter genes altamente co-expressos e de alto grau na vizinhança das sementes e isto sugere que o escore $X$ seja propício para encontrar Party Hubs (ver Seção 2.1.2). Por exemplo, ao fixarmos $N=100$ e compararmos os genes pertencentes às interseções:

- $\mathrm{Grau} \cap X$

- Grau $\cap$ RWR

observamos que dos 28 genes presentes em (Grau $\cap$ RWR), 27 estão presentes em (Grau $\cap X)$ apenas 1 não foi encontrado. Por outro lado, a interseção $(G r a u \cap X)$ possui 43 genes dos quais 16 não foram encontrados em (Grau $\cap$ RWR) mas que estão altamente relacionados à doença, conforme será discutido na Seção 6.1.4. Isso indica que o escore $X$ tem o potencial de capturar, na vizinhança das sementes, genes de alto grau mais relacionados com a doença que o RWR. Outro aspecto a destacar em relação as interseções do Grau com $X$ e RWR é que a partir de $N=400$, as interseções de $X$ com o Grau estabilizam, enquanto que RWR continua apresentando interseções crescentes com o Grau. Isso pode indicar que o RWR é mais suscetível ao viés da literatura.

Já as interseções do $\Delta^{\prime}$ e do DADA com o grau foram menores, sugerindo que são menos suscetíveis ao viés da literatura. Ressalta-se ainda que o ranqueamento do DADA é fortemente baseado no do RWR, exceto pelo fato de que o primeiro tenta priorizar genes de baixo grau em determinadas condições. Lembrando que o escore $\Delta^{\prime}$ busca priorizar as diferenças de co-expressão (com as sementes) dos genes nos caminhos mínimos selecionados em duas condições (controle e doença). Desta forma, o escore $\Delta^{\prime}$ é mais propício a descobrir novos genes associados a uma dada doença.

\subsection{Análise da Replicação dos Estudos}

Na seção 5.2.2, apresentamos um estudo de alguns parâmetros $\left(\epsilon, X_{i n i}\right)$ e seu impacto na seleção dos genes obtidos. Nesta seção, faremos uma análise da replicação dos primeiros genes ranqueados pelo escore $\Delta^{\prime}$ ( $\Delta$ normalizado) para os estudos KATO, ALTAR e BAHN. Para isto, após a priorização dos genes, avaliamos a interseção entre os resultados dos principais genes obtidos para cada um dos três estudos. A Figura 5.7 apresenta um gráfico comparativo das interseções entre os três estudos (KATO, ALTAR e BAHN) variando a quantidade de genes considerados entre 10 e 300. Para cada quantidade considerada, selecionamos os genes com os maiores escores normalizados $\Delta^{\prime}$ (ver Equação 3.4). Utilizamos dois valores para o parâmetro $X_{i n i}$ : 2 e 5 . É possível observar que a interseção entre os três estudos aumenta à medida que aumentamos o número de genes considerados. Observa-se ainda que para $X_{i n i}=5$ a interseção dos estudos foi sempre maior ou igual do que para $X_{i n i}=2$, sendo que a partir de 125 genes considerados esta diferença foi acentuada. Isto se deve ao fato de que o aumento do parâmetro $X_{i n i}$ reduz parte do ruído, ou seja, genes com intensidades $X$ muito baixas e que possivelmente não são relevantes biologicamente, por não terem importância topológica em relação aos genes sementes e nem serem co-expressos com eles.

Se por um lado, valores maiores de $X_{i n i}$ tendem a aumentar a replicabilidade (interseção) dos estudos, por outro, pode haver perda de informação, pois genes potencialmente relevantes podem 


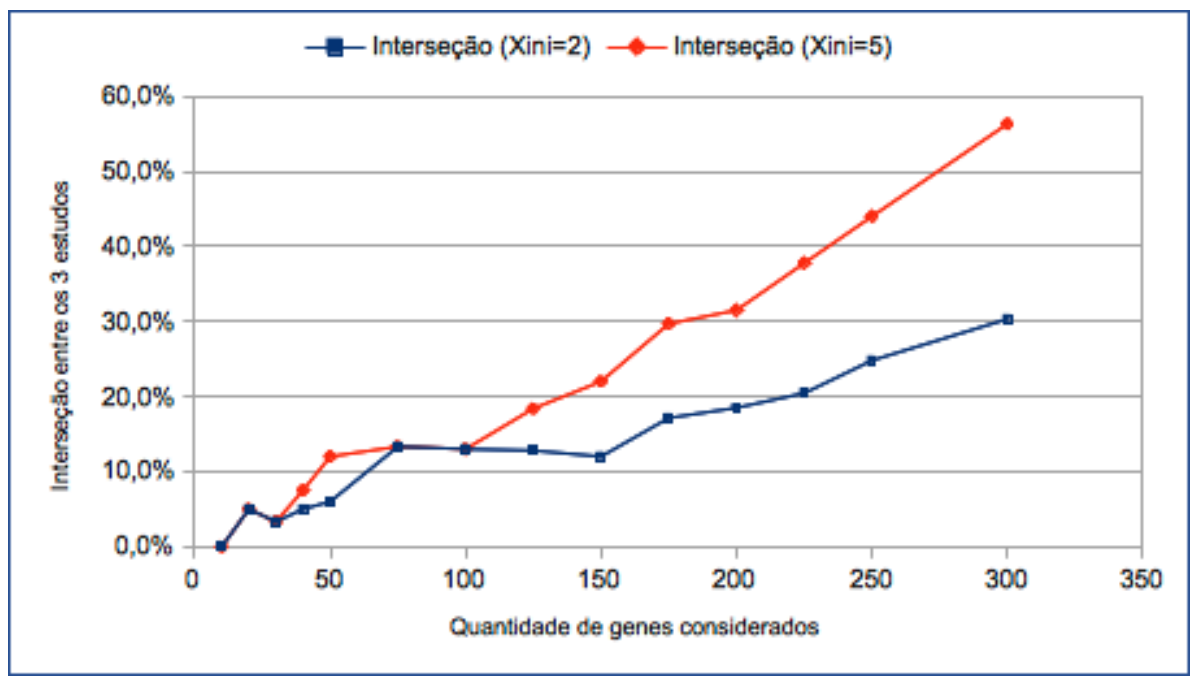

Figura 5.7: Comparação das sobreposições (overlaps) das listas dos primeiros genes ranqueados por $\Delta^{\prime}$ - para os 3 estudos KATO, ALTAR e BAHN, com valores de $X_{\text {ini }}=\{2,5\}$.

ser descartados. Desta forma, valores muito altos de $X_{i n i}$ acarretarão um número excessivo de falsos negativos enquanto valores muito baixos ocasionarão o oposto - excesso de falsos positivos. Portanto, o parâmetro $X_{\text {ini }}$ possui uma certa influência na replicação dos estudos, mas aconselha-se utilizar um valor que produza um bom balanço entre falsos positivos e falsos negativos.

Além desses dois valores ( 2 e 5) avaliados para $X_{\text {ini }}$, analisamos também outros valores (não apresentados aqui) que apresentaram resultados semelhantes - maiores valores de $X_{i n i}$ tendem a apresentar maiores interseções. A análise mostrou que utilizar um limiar $X_{i n i}=5$ é interessante porque considera apenas um subconjunto de aproximadamente $15 \%$ dos genes que possivelmente contém os mais relevantes biologicamente - de acordo com as hipóteses assumidas pelo nosso método. Por este motivo fixamos $X_{i n i}=5$ em nossas análises.

\subsubsection{Análise da Sobreposição entre os Resultados}

Conforme visto anteriormente, o método apresentado utiliza os escores $X$ e $\Delta^{\prime}$ que, por sua vez, são compostos pelas características $\sigma_{C}$ e $\sigma_{D}$ - que levam em consideração tanto aspectos topológicos quanto de co-expressão. $O$ escore $X$ representa a soma das características $\sigma_{C}$ e $\sigma_{D}$ (duas condições: controle e doença), ao passo que $\Delta^{\prime}$ representa a diferença relativa entre elas. Desta forma, o escore $X$ ranqueará melhor genes que tenham valor elevado em pelo menos uma das duas características. Por outro lado, $\Delta^{\prime}$ ranqueará melhor genes que estiverem alterados entre as duas condições, ou seja, que tiverem uma diferença relativa alta entre as características $\sigma_{C}$ e $\sigma_{D}$. Em outras palavras, não serão bem ranqueados por $\Delta^{\prime}$ genes que tiverem valores de $\sigma_{C}$ e $\sigma_{D}$ muito próximos, mesmo que a soma de tais valores seja elevada. Para estudarmos a replicação do método quando aplicado a diferentes estudos, analisamos a sobreposição dos respectivos resultados de $X$ e $\Delta^{\prime}$ para os estudos KATO, ALTAR e BAHN. 


\section{Sobreposição entre os Resultados - Escore $\Delta^{\prime}$}

A Figura 5.8 apresenta as interseções entre os estudos (KATO, ALTAR e BAHN) dos 10\% primeiros genes ranqueados por $\Delta^{\prime}$ (parâmetros utilizados: $\epsilon=0.05, X_{i n i}=5$ e percentual $=10 \%$ ). Foram comparados os $10 \%$ primeiros genes ranqueados por $\Delta^{\prime}$ em cada estudo, o que correspondeu a um total de 265, 284 e 276 genes respectivamente para KATO, ALTAR e BAHN - uma média de 275 genes por estudo. Observamos que a interseção entre os genes selecionados pelos três estudos foi de 129 genes, o que representa aproximadamente $46,9 \%$ da média de genes por estudo. É importante destacar que os genes pertencentes a esta interseção são aqueles que apresentaram características topológicas e de expressão desejáveis não apenas em um, mas simultaneamente nos três estudos. Desta forma, é necessário realizar uma análise biológica dessa lista de genes para verificar quais as suas características biológicas. As análises biológicas ( $G O$, inglesKEGG e doença) dos genes obtidos pela interseção do método aplicado aos três estudos são apresentadas no Capítulo 6.

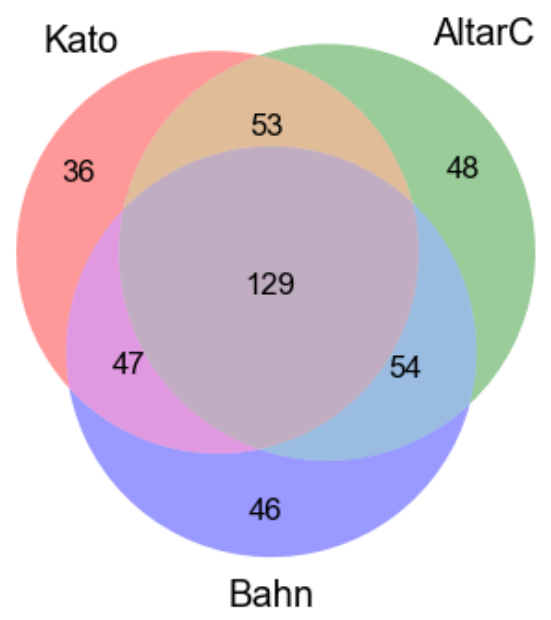

Figura 5.8: Interseção dos 10\% primeiros genes ranqueados por $\Delta^{\prime}$ em cada estudo: KATO, ALTAR e BAHN (parâmetros utilizados: $\epsilon=0.05, X_{\text {ini }}=5$ e percentual $=10 \%$ ).

A interseção apresentada na Figura 5.8 sugere que estes 129 genes apresentaram as maiores alterações de co-expressão (entre controle e doença) na vizinhança dos genes sementes. Lembrando que o escore $\Delta^{\prime}$ é composto tanto por fatores topológicos quanto de co-expressão, é fácil ver que os genes que ficaram de fora dessa interseção devem-se exclusivamente aos fatores de co-expressão. Entretanto, com relação aos genes da interseção, uma pergunta que surge naturalmente é: será que a interseção desses 129 genes deve-se exclusivamente a fatores topológicos? Ou analogamente: quanto a topologia está influenciando a seleção desses genes?

\section{Proporção de Ocorrência dos genes da Interseção nos Caminhos Possíveis}

Para avaliar o quanto a topologia está influenciando a interseção obtida entre os estudos, investigamos a proporção de ocorrência dos genes da interseção nos múltiplos caminhos mínimos possíveis entre os pares de genes explorados - conforme será descrito a seguir. Para facilitar o entendimento, 
suponha que um dado par de genes $(a, b)$, possua $N$ caminhos mínimos possíveis, e destes, $M$ caminhos passam pelo gene $g$. Definindo $P=M / N(0<P \leq 1)$ como a proporção de ocorrência do gene $g$ nos caminhos possíveis de $(a, b)$, se esta proporção for $P=1(100 \%)$, isto indicará que independente do caminho selecionado para o par, este obrigatoriamente deverá conter o gene $g$. Em outras palavras, se $P=1$, então a escolha de qualquer caminho entre os genes do par conterá o gene $g$, ou seja, a seleção do gene $g$ deve-se a razões puramente topológicas, independente da co-expressão. De maneira similar, se $P \approx 1$, então a escolha do gene $g$ para o dado par será majoritariamente devido a razões topológicas, com baixa influência da co-expressão. Analogamente, se $P \approx 0$ e ainda assim for escolhido um caminho que contenha o gene $g$, então a escolha de tal caminho se dará devido a aspectos de co-expressão e não a aspectos topológicos.

Uma forma de medir essa proporção de forma mais global, é calcularmos esta proporção também para todos pares em que $g$ pode ocorrer e, ao final, tirarmos a média das proporções $\left(\bar{P}=\sum_{i=1}^{T} P_{i} / T\right.$, onde $P_{i}$ é a proporção de caminhos que contem o gene $g$ para o par de genes número $i$, e $T$ é o total de pares de genes que contem algum caminho que passa por $g$ ). Se esta média das proporções for alta $(\bar{P} \approx 1)$, isto indicará que em todos os outros pares em que o gene $g$ pode ocorrer, os caminhos mínimos deverão passar por ele, não existindo caminhos alternativos e, portanto, sua seleção se dará exclusivamente por fatores topológicos. Por outro lado, se esta média for baixa $(\bar{P} \approx 0)$, isto indicará que a proporção de ocorrência do gene $g$ nos caminhos mínimos possíveis será baixa e que há diversos caminhos alternativos que não passam por $g$. Neste caso, se ainda assim o gene $g$ tiver sido escolhido na maioria dos pares, isto se deverá a fatores de coexpressão do gene $g$ com as sementes e não a fatores topológicos. Desta forma, para que o método encontre resultados biologicamente interessantes, é desejável que esta média das proporções de ocorrências do gene nos caminhos seja baixa. Assim, fizemos o cálculo destas proporções para todos os 129 genes e o histograma destas proporções são apresentados na 5.9.

Como podemos observar, a grande maioria (119 dos 129) dos genes apresentou uma baixa proporção $(\bar{P}<30 \%)$. Isto indica que para esta maioria de genes, na média cada par onde o gene ocorre há no mínimo $70 \%$ de caminhos alternativos que não passam pelo gene, e que sua escolha nos 3 estudos foi devido a sua co-expressão e não a fatores topológicos. Ou seja, o fato do gene pertencer a interseção indica que o método conseguiu, através da integração de dados, obter genes com evidência de alteração de co-expressão simultaneamente nos 3 estudos, sugerindo que estes genes são relevantes. Por outro lado, é possível observar um gene (ATXN1) cuja média de proporção de ocorrência nos caminhos foi de $72,7 \%$. Neste caso, os fatores topológicos foram os maiores responsáveis pela ocorrência do gene nos 3 estudos. Contudo, somente 5 genes possuem esta proporção média acima de 50\%, indicando que poucos genes foram obtidos por fatores predominantemente topológicos. Na seção seguinte, serão realizadas análises biológicas destes 129 genes obtidos na interseção destes estudos.

\section{Sobreposição entre os Resultados - Escore $X$}

Para fins de comparação com o escore $\Delta^{\prime}$, também apresentamos, na Figura 5.10, as interseções entre os estudos (KATO, ALTAR e BAHN) dos $10 \%$ primeiros genes ranqueados pelo escore $X$ (parâmetros utilizados: $\epsilon=0.05, X_{i n i}=5$ e percentual $=10 \%$ ). Visto que o escore $X$ é composto 


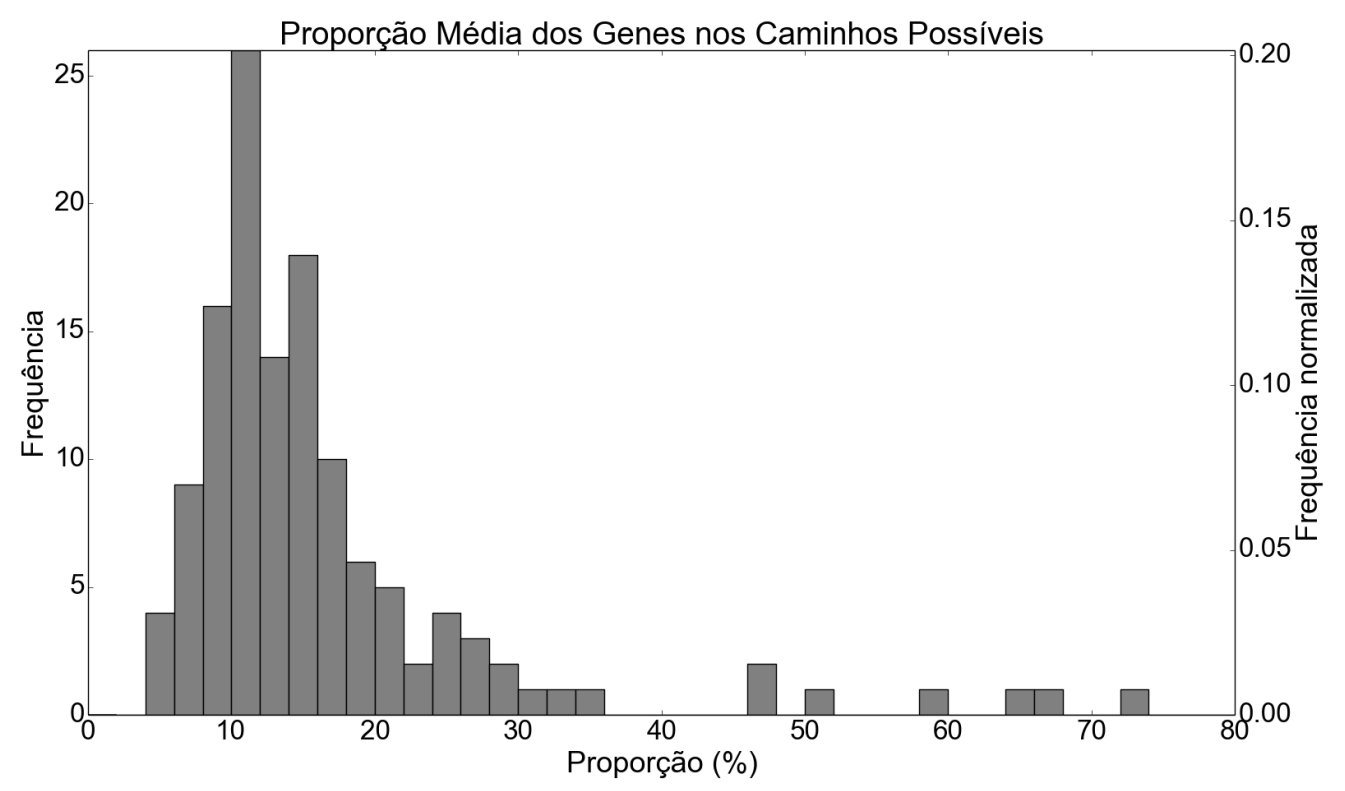

Figura 5.9: Proporção média de ocorrência dos genes nos caminhos possíveis. O eixo vertical esquerdo apresenta a frequência absoluta e o vertical direito apresenta a frequência normalizada. Observa-se que a grande maioria (maior frequência) dos genes apresentou proporção baixa (menor que 20\%) indicando que a seleção de tais genes foi devido a fatores de co-expressão e não a fatores topológicos.

pela soma das características $\left(\sigma_{C}\right.$ e $\left.\sigma_{D}\right)$ medidas para controle e doença, ele ranqueará melhor genes nos caminhos que estiverem mais co-expressos com os genes sementes em uma ou em ambas as condições, e ao mesmo tempo estiverem topologicamente próximos dos genes sementes na rede PPI. Nesse caso, um gene poderá ser bem ranqueado pelo escore $X$ mesmo que não esteja diferencialmente alterado entre as condições. Portanto, espera-se que a interseção do ranqueamento gerado pelo escore $X$ entre os diferentes estudos seja maior que a interseção do escore $\Delta^{\prime}$. Observamos na Figura 5.10 que a interseção dos genes ranqueados pelo escore $X$ resultantes entre os estudos KATO, ALTAR e BAHN, foi de aproximadamente 70,9\% (195/275), ou seja, foi maior que a interseção de $\Delta^{\prime}(46,9 \%)$. Assim, conforme esperado, o escore $X$ apresentou maiores interseções que o escore $\Delta^{\prime}$ entre os estudos, pois captura os genes em caminhos mais co-expressos com as sementes independentemente de estarem alterados nas duas condições. 


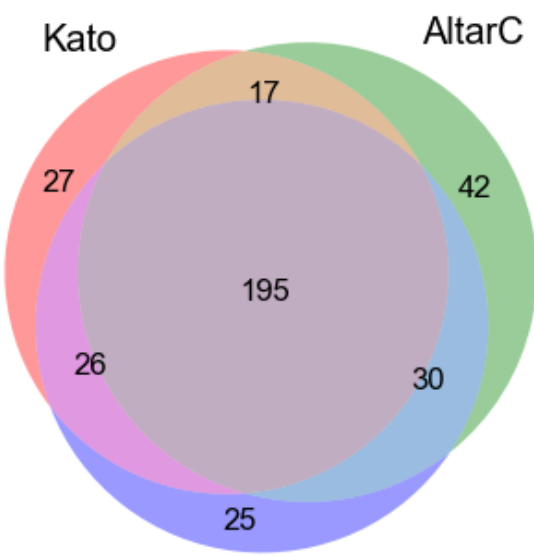

Bahn

Figura 5.10: Interseção dos $10 \%$ primeiros genes ranqueados por X em cada estudo: KATO, ALTAR e BAHN (parâmetros utilizados: $\epsilon=0.05, X_{\text {ini }}=5$ e percentual $=$ $10 \%)$. 


\section{Capítulo 6}

\section{Análises Biológicas}

Neste capítulo, são analisados biologicamente os $10 \%$ melhores genes obtidos pelos ranqueamentos dos escores $\Delta^{\prime}$ e $X$. Conforme mencionado na Seção 4.1.5, utilizamos as ferramentas: $G O$, KEGG e Disease - do site Webgestalt (WEB-based GEne SeT AnaLysis Toolkit) ${ }^{1}$ - para realizar a análise funcional dos genes obtidos, a análise das vias hiper-representadas, e a análise de associação dos genes a doenças. Primeiramente, são analisados os $10 \%$ melhores genes ranqueados por $\Delta^{\prime}$ obtidos a partir da aplicação do método ao estudo $\mathrm{KATO}^{2}$. A mesma análise é realizada para o ranqueamento $X$ aplicado ao estudo KATO. Em seguida, é analisada a lista de interseção dos $10 \%$ melhores genes ranqueados por $\Delta^{\prime}$ para os estudos KATO, ALTARC e BAHN, resultando em um conjunto de 129 genes. Também são analisados os 195 genes obtidos pela interseção dos $10 \%$ melhores genes ranqueados por $X$ nos 3 estudos.

\subsection{Estudo KATO}

Nesta seção, usamos o resultado do método aplicado ao estudo KATO para analisarmos os $10 \%$ (265) dos genes melhores classificados por $\Delta^{\prime}$, bem como os $10 \%$ (265) dos genes melhores classificados por $X$. Para ambas as listas de genes, são apresentadas as análises dos bancos de dados $G O$ e KEGG, bem como a análise de associação com doença. Importante mencionar que as mesmas análises também foram realizadas para os estudos ALTARC e BAHN, mas os resultados foram similares, e não serão apresentados para evitar análises redundantes.

\subsubsection{Ranqueamento $\Delta^{\prime}$}

\section{Análise GO}

Realizamos a análise $G O$ sobre esta lista de genes, buscando as 10 primeiras funções biológicas hiper-representadas com pelo menos 10 genes por função e adj $\mathrm{P}^{3}<0,01$. Na Figura B.1 (Apên-

\footnotetext{
${ }^{1}$ http://bioinfo.vanderbilt.edu/webgestalt/

${ }^{2}$ A aplicação do método individualmente aos demais estudos ALTARC e BAHN encontrou resultados similares ao KATO e por isso não são apresentados.

${ }^{3}$ adjP: p-valor ajustado por múltiplos testes.
} 
dice B) são apresentadas as categorias de $G O^{1}$ (Gene Ontology) significantemente enriquecidas nos processos biológicos, através de um grafo acíclico dirigido (DAG - Directed Acyclic Graph). Cada categoria de $G O$ é um nó do $D A G$, no qual em vermelho estão as categorias enriquecidas e em preto os nós que não estão enriquecidos. É possível observar nessa figura que as categorias mais comuns observadas são: desenvolvimento celular, morte celular, comunicação celular, transdução de sinal, regulação da comunicação celular, regulação da transdução de sinal, regulação da sinalização, dentre outras. Podemos destacar nesta figura as seguintes funções biológicas hiperrepresentadas: regulação da transdução de sinal ( $\operatorname{adjP}=6,02 \mathrm{e}-25)$; via de sinalização do receptor do fator de crescimento neuronal (adjP $=1,16 \mathrm{e}-24)$; regulação da cascata intracelular da proteína kinase (adjP = 4,05e-24); fosforilação de proteínas (adjP = 1,16e-24).

\section{Análise KEGG}

Utilizando os 265 genes selecionados anteriormente (com os mesmos parâmetros já descritos), realizamos as análises KEGG para verificar as vias hiper-representadas. A Figura 6.1 mostra as 10 primeiras vias mais hiper-representadas, e dentre estas, podemos destacar: vias de sinalização neurotrofina (adjP = 7,85e-34); vias em câncer (adjP = 1,08e-32); via de sinalização MAPK (adjP $=1,15 \mathrm{e}-31)$; adesão focal ( $\operatorname{adjP}=1,53 \mathrm{e}-28)$ e via de sinalização ErbB $(\operatorname{adjP}=3,68 \mathrm{e}-25)$. A Figura C.1 (Apêndice C) ilustra a localização dos genes hiper-representados obtidos pelo escore $\Delta^{\prime}$ na via de sinalização ErbB.

\begin{tabular}{|c|c|c|c|}
\hline PathwayName & \#Gene & EntrezGene & Statistics \\
\hline $\begin{array}{l}\text { Neurotrophin signaling } \\
\text { pathway }\end{array}$ & 28 & $\begin{array}{l}559971896738767589452955879801715756041097148042309 \\
2885366753353654646455803551578129325603421755945970 \\
52944214\end{array}$ & $\begin{array}{l}\mathrm{C}=127 ; \mathrm{O}=28 ; \mathrm{E}=0.78 ; \mathrm{R}=36.02 ; \\
\operatorname{raw} \mathrm{P}=1.54 \mathrm{e}-35 ; \operatorname{adj} \mathrm{P}=7.85 \mathrm{e}-34\end{array}$ \\
\hline Pathways in cancer & 36 & $\begin{array}{l}55997189836673230858945879715756042064557841935728 \\
3551431359701856704022477039101933265295195628854088 \\
53354087675831284532932677655945294405\end{array}$ & $\begin{array}{l}C=326 ; O=36 ; E=2.00 ; R=18.04 ; \\
\text { raw }=4.25 e-34 ; \operatorname{adj} P=1.08 e-32\end{array}$ \\
\hline MAPK signaling pathway & 33 & $\begin{array}{l}559971898366735894587910912715756045578556635515971 \\
54945970421423187040224731643312512952316592119563554 \\
28854085603421755364095594\end{array}$ & $\begin{array}{l}\mathrm{C}=268 ; \mathrm{O}=33 ; \mathrm{E}=1.64 ; \mathrm{R}=20.12 ; \\
\operatorname{rawP}=6.74 \mathrm{e}-33 ; \operatorname{adj} \mathrm{P}=1.15 \mathrm{e}-31\end{array}$ \\
\hline Focal adhesion & 28 & 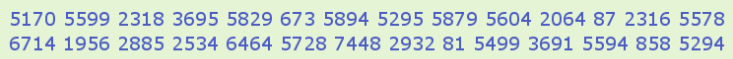 & $\begin{array}{l}\mathrm{C}=200 ; \mathrm{O}=28 ; \mathrm{E}=1.22 ; \mathrm{R}=22.87 ; \\
\operatorname{rawP}=1.20 \mathrm{e}-29 ; \operatorname{adj} \mathrm{P}=1.53 \mathrm{e}-28\end{array}$ \\
\hline Pancreatic cancer & 19 & $\begin{array}{l}704055996735894101970395295587971575604206419564088 \\
67540873551597055945294\end{array}$ & $\begin{array}{l}C=70 ; O=19 ; E=0.43 ; R=44.34 \\
\operatorname{raw} P=2.22 \mathrm{e}-26 ; \operatorname{adj} P=2.26 \mathrm{e}-25\end{array}$ \\
\hline ErbB signaling pathway & 20 & $\begin{array}{l}559967346905894703952955604206455786714195628855335 \\
6464844029326776206555945294\end{array}$ & $\begin{array}{l}C=87 ; O=20 ; E=0.53 ; R=37.55 \\
\operatorname{raw} P=4.33 e-26 ; \operatorname{adj} P=3.68 \mathrm{e}-25\end{array}$ \\
\hline Prostate cancer & 20 & $\begin{array}{l}517067323083326589470395295715756042064195628854193 \\
5728355129321385597055945294\end{array}$ & $\begin{array}{l}C=89 ; O=20 ; E=0.54 ; R=36.71 \\
\text { raw } P=7.16 e-26 ; \operatorname{adj} P=5.22 e-25\end{array}$ \\
\hline $\begin{array}{l}\text { Chagas disease (American } \\
\text { trypanosomiasis) }\end{array}$ & 20 & $\begin{array}{l}7040559971895295232362770811551540884087365455182775 \\
3551277656035521597055945294\end{array}$ & $\begin{array}{l}\mathrm{C}=104 ; \mathrm{O}=20 ; \mathrm{E}=0.64 ; \mathrm{R}=31.42 ; \\
\operatorname{rawP}=2.13 \mathrm{e}-24 ; \operatorname{adj} \mathrm{P}=1.36 \mathrm{e}-23\end{array}$ \\
\hline Glioma & 17 & $\begin{array}{l}67358941019703952958017157560455781956288553354193 \\
6464572855945294\end{array}$ & $\begin{array}{l}\mathrm{C}=65 ; \mathrm{O}=17 ; \mathrm{E}=0.40 ; \mathrm{R}=42.72 \\
\operatorname{rawP}=2.03 \mathrm{e}-23 ; \operatorname{adj} \mathrm{P}=1.15 \mathrm{e}-22\end{array}$ \\
\hline Non-small cell lung cancer & 16 & $\begin{array}{l}517067358941019703952957157560420645578230919562885 \\
533555945294\end{array}$ & $\begin{array}{l}C=54 ; O=16 ; E=0.33 ; R=48.40 \\
\operatorname{rawP}=4.21 \mathrm{e}-23 ; \operatorname{adj} P=2.15 e-22\end{array}$ \\
\hline
\end{tabular}

Figura 6.1: Vias hiper-representadas para os $10 \%$ (265) primeiros genes ranqueados pelo escore $\Delta^{\prime}$ aplicado aos estudos KATO. Podemos destacar algumas vias relacionadas à esquizofrenia: vias de sinalização neurotrofina; vias em câncer; via de sinalização MAPK; adesão focal e via de sinalização ErbB.

\footnotetext{
${ }^{1}$ Utilizou-se os seguintes parâmetros nas análises de Organism: hsapiens, Id Type: gene_symbol, Ref Set: genome, i.e. entire entrez gene list, Statistic: Hypergeometric, Signficance Level: .01, MTC: BH, Minimum: 10.
} 


\section{Análise de doenças hiper-representadas}

Na Tabela 6.1, destacamos algumas doenças ${ }^{1}$ encontradas hiper-representadas: câncer $(\operatorname{adjP}=$ 5.45e-29), estresse (adjP $=8.62 \mathrm{e}-32$ ), neuroblastoma (adjP $=5.01 \mathrm{e}-13$ ), distúrbios mentais (adjP $=2.08 \mathrm{e}-10)$ e doenças de pele $(\operatorname{adj} \mathrm{P}=1.27 \mathrm{e}-14)$. Além disso, diferentes transtornos psiquiátricos foram hiper-representados (dados não mostrados).

\begin{tabular}{|c|c|c|c|}
\hline Disease & $\begin{array}{l}\# \quad \text { of } \\
\text { Genes }\end{array}$ & EntrezGene & Statistics \\
\hline $\begin{array}{l}\text { Drug interaction } \\
\text { with drug }\end{array}$ & 65 & $\begin{array}{l}5599836718958947157206455784193511164647448530035515499597011140 \\
33263312743087408836895335253440872185293281741255944094055764 \\
23086714558181128905580578118144904206596013856667517058291558 \\
224729088015295290210399195628858202490528864086776277696115294\end{array}$ & $\begin{array}{l}\mathrm{C}=349 ; \quad \mathrm{O}=65 ; \quad \mathrm{E}=2.14 \\
\mathrm{R}=30.43 ; \text { rawP=2.92e- } 77 \\
\text { adjP=3.27e-75 }\end{array}$ \\
\hline Stress & 40 & $\begin{array}{l}5599836507158797157613541936464530035515494197759702341133263312 \\
872316837544525473014815603119155365594230823098878558049043329 \\
1385421429083313306442173875\end{array}$ & $\begin{array}{l}\mathrm{C}=464 ; \quad \mathrm{O}=40 ; \quad \mathrm{E}=2.84 \\
\mathrm{R}=14.08 ; \text { rawP=1.54e-33; } \\
\text { adjP=8.62e-32 }\end{array}$ \\
\hline $\begin{array}{l}\text { cancer or viral in- } \\
\text { fections }\end{array}$ & 49 & $\begin{array}{l}5599836589456047157206489186585111419353001977597010197430672995 \\
4088458267540878312254730141500103205594272506732308230967145728 \\
4313490420659961960666770402175195682025174128866776369110005294\end{array}$ & $\begin{array}{l}\mathrm{C}=951 ; \quad \mathrm{O}=49 ; \quad \mathrm{E}=5.82 \\
\mathrm{R}=8.42 ; \quad \text { rawP }=1.46 \mathrm{e}-30 \\
\text { adj } \mathrm{P}=5.45 \mathrm{e}-29\end{array}$ \\
\hline Death & 32 & $\begin{array}{l}55998365071718971574193705259708767331283725473014293211915594 \\
27250230887172309558136545580316429024804517413064641842173875 \\
5294\end{array}$ & $\begin{array}{l}\mathrm{C}=343 ; \quad \mathrm{O}=32 ; \quad \mathrm{E}=2.10 \\
\mathrm{R}=15.24 ; \text { rawP }=4.85 \mathrm{e}-28 \\
\text { adjP=1.36e- } 26\end{array}$ \\
\hline Skin Diseases & 23 & $\begin{array}{l}7157206441931019672385845826756735728431349042065310796042147040 \\
1956820251741288667763691\end{array}$ & $\begin{array}{l}\mathrm{C}=417 ; \quad \mathrm{O}=23 ; \quad \mathrm{E}=2.55 \\
\mathrm{R}=9.01 ; \quad \text { rawP }=2.15 \mathrm{e}-15 \\
\text { adjP=1.27e-14 }\end{array}$ \\
\hline Neuroblastoma & 17 & $\begin{array}{l}83650717157419370522932231141191203068874523095581138566674804 \\
33134692\end{array}$ & $\begin{array}{l}\mathrm{C}=229 ; \quad \mathrm{O}=17 ; \quad \mathrm{E}=1.40 \\
\mathrm{R}=12.13 ; \text { rawP=8.94e-14; } \\
\text { adjP=5.01e-13 }\end{array}$ \\
\hline Astrocytoma & 13 & 587971575578275210195764874567357285584490495451956 & $\begin{array}{l}\mathrm{C}=121 ; \quad \mathrm{O}=13 ; \quad \mathrm{E}=0.74 \\
\mathrm{R}=17.55 ; \text { rawP=6.87e-13; } \\
\text { adjP=3.66e-12 }\end{array}$ \\
\hline $\begin{array}{l}\text { Neuroectodermal } \\
\text { Tumors }\end{array}$ & 18 & $\begin{array}{l}58797157557841931019231657646735728431355842065638696048041956 \\
27761000\end{array}$ & $\begin{array}{l}\mathrm{C}=313 ; \quad \mathrm{O}=18 ; \quad \mathrm{E}=1.92 \\
\mathrm{R}=9.39 ; \quad \operatorname{rawP}=1.29 \mathrm{e}-12 \\
\operatorname{adj} \mathrm{P}=6.57 \mathrm{e}-12\end{array}$ \\
\hline Adenocarcinoma & 19 & $\begin{array}{l}7157206441937039743067245826751500272506735728431320659601956 \\
5174138751000\end{array}$ & $\begin{array}{l}\mathrm{C}=362 ; \quad \mathrm{O}=19 ; \quad \mathrm{E}=2.22 \\
\mathrm{R}=8.57 ; \quad \text { raw } \mathrm{P}=1.51 \mathrm{e}-12 \\
\text { adj } \mathrm{P}=7.35 \mathrm{e}-12\end{array}$ \\
\hline Mental Disorders & 21 & $\begin{array}{l}2752291547415300174229321191259971815289018143481385454327185 \\
85732908290248043064\end{array}$ & $\begin{array}{l}\mathrm{C}=564 ; \quad \mathrm{O}=21 ; \quad \mathrm{E}=3.45 \\
\mathrm{R}=6.08 ; \quad \operatorname{rawP}=6.31 \mathrm{e}-11 \\
\operatorname{adj} \mathrm{P}=2.08 \mathrm{e}-10\end{array}$ \\
\hline
\end{tabular}

Tabela 6.1: Destaque para algumas doenças hiper-representadas nos primeiros 10\% genes ranqueados pelo escore $\Delta^{\prime}$ aplicado ao estudo KATO.

\subsubsection{Ranqueamento $X$}

Todas as análises mencionadas anteriormente na Seção 6.1.1 (para o ranqueamento $\Delta^{\prime}$ ), também foram realizadas para o ranqueamento $X$, utilizando os $10 \%$ de genes melhores classificados pelo escore $X$. As vias biológicas obtidas pelo ranqueamento $X$ foram semelhantes às obtidas pelo ranqueamento $\Delta^{\prime}$, conforme apresentados a seguir.

\section{Análise GO}

Realizamos a análise GO sobre esta lista dos $10 \%$ (265) melhores genes ranqueados por $X$ nas mesmas condições realizadas nas análises do ranqueamento $\Delta^{\prime}$ - buscando as 10 primeiras funções biológicas hiper-representadas com pelo menos 10 genes por função e adjP $<0,01$. Na Figura B.2 (Apêndice B) são apresentadas as categorias de $G O^{2}$ significantemente enriquecidas

\footnotetext{
${ }^{1}$ Parâmetros utilizados nas análises de doenças: (Organism: hsapiens, Id Type: gene_symbol, Ref Set: entrezgene, Significance Level: .01, Statistics Test: Hypergeometric, MTC: BH, Minimum: 10).

${ }^{2}$ Parâmetros utilizados nas análises GO: (Organism: hsapiens, Id Type: gene_symbol, Ref Set: genome, i.e. entire entrez gene list, Statistic: Hypergeometric, Signficance Level: .01, MTC: BH, Minimum: 10).
} 
nos processos biológicos. Podemos destacar nesta figura as seguintes funções hiper-representadas: regulação da transdução de sinal ( $\operatorname{adjP}=1,90 \mathrm{e}-41)$; regulação da comunicação celular (adjP = 1,34e-41); regulação da cascata intracelular da proteína kinase ( $\operatorname{adjP}=5,21 \mathrm{e}-36)$; fosforilação de proteínas (adjP = 9,36e-42).

\section{Análise KEGG}

A análise KEGG para o conjunto de genes classificados pelo escore $X$ foi realizada utilizando os mesmos parâmetros usados para o escore $\Delta^{\prime}$. A Figura 6.2 apresenta 10 primeiras vias mais hiper-representadas, e dentre estas, podemos destacar: vias em câncer (adjP = 9,20e-50); via de sinalização MAPK (adjP = 1,07e-38); vias de sinalização neurotrofina (adjP = 1,09e-37); via de sinalização ErbB (adjP = 9,50e-36) e adesão focal (adjP = 2,75e-27). A Figura C.2 (Apêndice C)

\begin{tabular}{|c|c|c|c|}
\hline PathwayName & \#Gene & EntrezGene & Statistics \\
\hline Pathways in cancer & 48 & $\begin{array}{l}2033718983671867157206470463241147102655782513873725592541939981499 \\
5728460943135601529033205970185659142073326529519562885408885175335 \\
408713985579831247925371293236767765594101730661029\end{array}$ & $\begin{array}{l}C=326 ; O=48 ; E=2.00 ; R=24.05 ; \\
\text { rawP }=1.46 e-51 ; \operatorname{adj} P=9,20 e-50\end{array}$ \\
\hline MAPK signaling pathway & 38 & $\begin{array}{l}7189836718610912715770461147557855661432372599846095601506254946885 \\
59701386505842155530207316433125129523165921195628853554851713985579 \\
5536559461974137\end{array}$ & $\begin{array}{l}C=268 ; O=38 ; E=1.64 ; R=23.16 ; \\
\text { rawP }=3.41 \mathrm{e}-40 ; \operatorname{adj} P=1.07 \mathrm{e}-38\end{array}$ \\
\hline $\begin{array}{l}\text { Neurotrophin signaling } \\
\text { pathway }\end{array}$ & 30 & $\begin{array}{l}42157189207529580171571097175311432566328852537253667533564649981398 \\
558056014792578152902932753475335594597075296197\end{array}$ & $\begin{array}{l}C=127 ; O=30 ; E=0.78 ; R=38.59 ; \\
\text { rawP }=5.20 \mathrm{e}-39 ; \operatorname{adj} P=1.09 \mathrm{e}-37\end{array}$ \\
\hline ErbB signaling pathway & 26 & $\begin{array}{l}505820746905295206410265578671420661956288525372553351398646455794609 \\
56015062844052902932677620655594\end{array}$ & $\begin{array}{l}C=87 ; O=26 ; E=0.53 ; R=48.82 \\
\text { rawP }=6.03 \mathrm{e}-37 ; \operatorname{adj} P=9.50 \mathrm{e}-36\end{array}$ \\
\hline Chronic myeloid leukemia & 23 & $\begin{array}{l}207529571577046114710262885254088592585174193139864644609479257815290 \\
67765594597010293066\end{array}$ & $\begin{array}{l}C=73 ; O=23 ; E=0.45 ; R=51.47 \\
\text { rawP }=2.04 \mathrm{e}-33 ; \text { adjP } P 2.57 \mathrm{e}-32\end{array}$ \\
\hline Prostate cancer & 24 & $\begin{array}{l}2033207332652957157206411471026195628851387851759254193149957284792 \\
529029323673320559410175970\end{array}$ & $\begin{array}{l}C=89 ; O=24 ; E=0.54 ; R=44.05 \\
\text { rawP }=5.98 \mathrm{e}-33 ; \operatorname{adj} P=6.28 \mathrm{e}-32\end{array}$ \\
\hline $\begin{array}{l}\text { T cell receptor signaling } \\
\text { pathway }\end{array}$ & 23 & $\begin{array}{l}505855302074690529511471432288537255335851725349985601506247928440 \\
529017392932688555945970\end{array}$ & $\begin{array}{l}C=108 ; O=23 ; E=0.66 ; R=34.79 ; \\
\operatorname{rawP}=5.41 \mathrm{e}-29 ; \operatorname{adj} P=4.87 \mathrm{e}-28\end{array}$ \\
\hline Focal adhesion & 27 & $\begin{array}{l}50582075295206488231655786714195628853725253464649981499139857285579 \\
560150625290293260549936915594858\end{array}$ & $\begin{array}{l}C=200 ; O=27 ; E=1.22 ; R=22.05 \\
\text { rawP }=3.49 \mathrm{e}-28 ; \mathrm{adj} P=2.75 \mathrm{e}-27\end{array}$ \\
\hline Wnt signaling pathway & 24 & $\begin{array}{l}20335530715714571460324557855662323656635515408813873725408714995579 \\
8312460956012932688518561459\end{array}$ & $\begin{array}{l}\mathrm{C}=150 ; \mathrm{O}=24 ; \mathrm{E}=0.92 ; \mathrm{R}=26.14 ; \\
\text { rawP }=5.18 \mathrm{e}-27 ; \mathrm{adj}=3.63 \mathrm{e}-26\end{array}$ \\
\hline $\begin{array}{l}\text { Chagas disease (American } \\
\text { trypanosomiasis) }\end{array}$ & 21 & $\begin{array}{l}7189207529570461147232361432277055153725811408885174087560147925290 \\
2776559427715970\end{array}$ & $\begin{array}{l}C=104 ; O=21 ; E=0.64 ; R=32.99 ; \\
\text { rawP }=4.84 \mathrm{e}-26 ; \operatorname{adj} P=3.05 \mathrm{e}-25\end{array}$ \\
\hline Adherens junction & 19 & $\begin{array}{l}2033206414577046146088671419561387408840875795253499814996068855594 \\
1459\end{array}$ & $\begin{array}{l}C=73 ; O=19 ; E=0.45 ; R=42.52 \\
\text { rawP }=5.48 \mathrm{e}-26 ; \operatorname{adj} P=3.14 \mathrm{e}-25\end{array}$ \\
\hline Cell cycle & 22 & $\begin{array}{l}20335591109127157109711026753125408813875925511140874193460929327534 \\
75331017752930661029\end{array}$ & $\begin{array}{l}C=124 ; O=22 ; E=0.76 ; R=28.98 ; \\
\text { rawP }=6.73 \mathrm{e}-26 ; a d j P=3.53 e-25\end{array}$ \\
\hline
\end{tabular}

Figura 6.2: Vias hiper-representadas para os $10 \%$ (265) primeiros genes ranqueados pelo escore X aplicado ao estudos KATO. Podemos destacar algumas vias: vias em câncer; via de sinalização MAPK; vias de sinalização neurotrofina; via de sinalização ErbB e adesão focal.

apresenta, para o escore $X$, os genes hiper-representados pertencentes à via de sinalização ErbB.

\section{Análise de doenças hiper-representadas}

Algumas doenças hiper-representadas presentes nessa lista são exibidas na Tabela 6.2, dentre as quais destacam-se: câncer e infecções virais ( $\operatorname{adj} \mathrm{P}=1.84 \mathrm{e}-35)$, estresse (adjP $=2.87 \mathrm{e}-46$ ), doenças mentais (adj $\mathrm{P}=1.33 \mathrm{e}-26$ ) e alguns transtornos psiquiátricos incluindo esquizofrenia (adjP $=5.40 \mathrm{e}$ 16). É possível observar, por exemplo, que o número de genes relacionados a transtornos mentais obtidos pelo ranqueamento $X$ foi de 38 , um aumento em relação ao ranqueamento $\Delta^{\prime}$ que obteve 21 genes relacionados ao mesmo transtorno. 


\begin{tabular}{|c|c|c|c|}
\hline Disease & $\begin{array}{l}\# \quad \text { of } \\
\text { Genes }\end{array}$ & EntrezGene & Statistics \\
\hline $\begin{array}{l}\text { Drug interaction } \\
\text { with drug }\end{array}$ & 72 & $\begin{array}{l}203383671897157206455781432946313874193511164641499530052905499 \\
5970111405914207332633124035743166224088368985175335253440875590 \\
7251293274123838605594306657646714558137258112890558057814904 \\
33202065960681266671813290880152952902103991547316195629042885 \\
490521368043672776677696112099\end{array}$ & $\begin{array}{l}\mathrm{C}=349 ; \quad \mathrm{O}=72 ; \quad \mathrm{E}=2.14 \\
\mathrm{R}=33.70 ; \text { rawP=2.37e- } 89 \\
\text { adjP=3.55e-87 }\end{array}$ \\
\hline Stress & 51 & $\begin{array}{l}7874836715711471026143235161351020419399864645300549413865970 \\
2341125972073326330933122316837662254452547301460119155365594 \\
71863725251938560155804904332068853329505829087316331330644792 \\
537175343240\end{array}$ & $\begin{array}{l}\mathrm{C}=464 ; \quad \mathrm{O}=51 ; \quad \mathrm{E}=2.84 \\
\mathrm{R}=17.96 ; \text { rawP=3.83e- } 48 \\
\text { adjP=2.87e-46 }\end{array}$ \\
\hline Death & 43 & $\begin{array}{l}8367189715711471026143235156211020419370525970259720733093312837 \\
6622851725473014293211915594413771865663372555818626460956015580 \\
8345591316429027316290430645174153717529\end{array}$ & $\begin{array}{l}\mathrm{C}=343 ; \quad \mathrm{O}=43 ; \quad \mathrm{E}=2.10 \\
\mathrm{R}=20.48 ; \operatorname{rawP}=4.55 \mathrm{e}-43 \\
\operatorname{adj} \mathrm{P}=2.28 \mathrm{e}-41\end{array}$ \\
\hline HIV & 55 & $\begin{array}{l}2033836568410015556514571052414605578143255661387529017855499 \\
597013157431368953352534413355795590725174123838601098068805594 \\
1173638310055813725360356015062558073148341459666750582908801 \\
529529022323697822904331347921017\end{array}$ & $\begin{array}{l}\mathrm{C}=755 ; \quad \mathrm{O}=55 ; \quad \mathrm{E}=4.62 \\
\mathrm{R}=11.90 ; \text { rawP }=3.20 \mathrm{e}-42 \\
\text { adjP=1.20e-40 }\end{array}$ \\
\hline $\begin{array}{l}\text { cancer or viral in- } \\
\text { fections }\end{array}$ & 55 & $\begin{array}{l}83671571052420643241026206651114193149953005290597059142073309 \\
7431672408840875795831225473014559430667046671437252559252048 \\
5728862646094313490437173320206596066675058559121001956517415371 \\
367677636912099101710001029\end{array}$ & $\begin{array}{l}\mathrm{C}=951 ; \quad \mathrm{O}=55 ; \quad \mathrm{E}=5.82 \\
\mathrm{R}=9.45 ; \quad \text { rawP }=6.15 \mathrm{e}-37 \\
\text { adjP }=1.84 \mathrm{e}-35\end{array}$ \\
\hline $\begin{array}{l}\text { Cell Transforma- } \\
\text { tion, Neoplastic }\end{array}$ & 31 & $\begin{array}{l}7157105242064102641936464149953005290234112074088579513987251 \\
293267142559255728460957813717505852951956288596415174153711029\end{array}$ & $\begin{array}{l}\mathrm{C}=233 ; \quad \mathrm{O}=31 ; \quad \mathrm{E}=1.43 \\
\mathrm{R}=21.73 ; \text { rawP }=5.07 \mathrm{e}-32 \\
\operatorname{adj} \mathrm{P}=1.27 \mathrm{e}-30\end{array}$ \\
\hline Mental Disorders & 38 & $\begin{array}{l}109892898275235120669463562110204741334530025974035174296386622 \\
4133293211917804413725997289156632890333348936646812271851813 \\
290874362902290430646197\end{array}$ & $\begin{array}{l}\mathrm{C}=564 ; \quad \mathrm{O}=38 ; \quad \mathrm{E}=3.45 \\
\mathrm{R}=11.01 ; \text { rawP }=6.20 \mathrm{e}-28 \\
\text { adjP=1.33e-26 }\end{array}$ \\
\hline Dementia & 28 & $\begin{array}{l}836289855662752351562110204741334530025974035662241332932119119 \\
780441377276256633333487314290229043064\end{array}$ & $\begin{array}{l}\mathrm{C}=247 ; \quad \mathrm{O}=28 ; \quad \mathrm{E}=1.51 \\
\mathrm{R}=18.52 ; \text { rawP }=5.09 \mathrm{e}-27 \\
\text { adjP=8.48e-26 }\end{array}$ \\
\hline Breast Diseases & 30 & $\begin{array}{l}715720641026206641931499530052902072699467240773066671459255728 \\
4609431349042065960505821001956517413671655677636912099\end{array}$ & $\begin{array}{l}\mathrm{C}=350 ; \quad \mathrm{O}=30 ; \quad \mathrm{E}=2.14 \\
\mathrm{R}=14.00 ; \text { rawP=2.98e-25; } \\
\text { adjP=4.06e- } 24\end{array}$ \\
\hline $\begin{array}{l}\text { Neurodegenerative } \\
\text { Diseases }\end{array}$ & 31 & $\begin{array}{l}35156211020474133466325300178570521639259733124035631066225445 \\
413329321191780420306841377276256633333487314951629043064\end{array}$ & $\begin{array}{l}\mathrm{C}=404 ; \quad \mathrm{O}=31 ; \quad \mathrm{E}=2.47 \\
\mathrm{R}=12.54 ; \text { rawP }=1.31 \mathrm{e}-24 \\
\text { adj } \mathrm{P}=1.64 \mathrm{e}-23\end{array}$ \\
\hline $\begin{array}{l}\text { Alzheimer Dise- } \\
\text { ase }\end{array}$ & 23 & $\begin{array}{l}5566351562110203345300259740356622544525344133293211911978044137 \\
7276256633333487314\end{array}$ & $\begin{array}{l}\mathrm{C}=203 ; \quad \mathrm{O}=23 ; \quad \mathrm{E}=1.24 \\
\mathrm{R}=18.51 ; \text { rawP }=2.23 \mathrm{e}-22 \\
\text { adjP=2.09e-21 }\end{array}$ \\
\hline Adhesion & 32 & $\begin{array}{l}14326464149999870522074690231636892534139884407412559478046383 \\
886714252048431357816386960505874361039928851600840436911000\end{array}$ & $\begin{array}{l}\mathrm{C}=647 ; \quad \mathrm{O}=32 ; \quad \mathrm{E}=3.96 \\
\mathrm{R}=8.08 ; \quad \text { rawP }=1.31 \mathrm{e}-19 \\
\text { adjP=9.36e-19 }\end{array}$ \\
\hline Neuroblastoma & 20 & $\begin{array}{l}836715735156214193705259142076622293211914137203068566355812048 \\
4609666773163313\end{array}$ & $\begin{array}{l}\mathrm{C}=229 ; \quad \mathrm{O}=20 ; \quad \mathrm{E}=1.40 ; \\
\mathrm{R}=14.27 ; \text { rawP=2.33e-17; } \\
\text { adjP=1.59e-16 }\end{array}$ \\
\hline $\begin{array}{l}\text { Neuroectodermal } \\
\text { Tumors }\end{array}$ & 22 & $\begin{array}{l}715710265578206641931499529020723164133576459255728460943136386 \\
20659601956277610001029\end{array}$ & $\begin{array}{l}\mathrm{C}=313 ; \quad \mathrm{O}=22 ; \quad \mathrm{E}=1.92 ; \\
\mathrm{R}=11.48 ; \text { rawP=5.81e-17; } \\
\text { adjP=3.63e-16 }\end{array}$ \\
\hline Schizophrenia & 23 & $\begin{array}{l}1098950482752206694634741207963817422932599728912890413068126709 \\
271851813290223236290468047533\end{array}$ & $\begin{array}{l}\mathrm{C}=360 ; \quad \mathrm{O}=23 ; \quad \mathrm{E}=2.20 \\
\mathrm{R}=10.44 ; \text { rawP } \\
\text { adjP=5.00e-17; }\end{array}$ \\
\hline
\end{tabular}

Tabela 6.2: Destaque para algumas doenças hiper-representadas nos $10 \%$ genes melhores classificados pelo escore X aplicado ao estudo KATO. Parâmetros utilizados: (Organism: hsapiens, Id Type: gene_symbol, Ref Set: entrezgene, Significance Level: .01, Statistics Test: Hypergeometric, MTC: BH, Minimum: 10). 


\subsubsection{Discussão dos resultados}

De acordo com nossas análises podemos dizer que processos biológicos já relacionados a esquizofrenia [Beaulieu et al., 2005; Fan et al., 2012; Sun et al., 2010], podem ser destacados como comunicação celular, processo de desenvolvimento, morte celular e proliferação celular. Da mesma forma estes processos foram reagrupados nas análises de vias biológicas. A via de câncer foi a mais enriquecida, e isto se deve ao fato dela estar relacionada com todas as demais vias, além de que os processos de carcinogênese relacionam-se aos processos do desenvolvimento embrionário, uma vez que um tumor pode ser visto como um desenvolvimento anômalo. Ou seja, é produto não de uma diferenciação celular e sim de proliferação celular. Hoje esquizofrenia é considerada uma desordem do neurodesenvolvimento [Debnath et al., 2015]. A via da sinalização MAPK [Maycox et al., 2009] relaciona-se à outras vias importantes como apoptose [Gassó et al., 2014], ciclo celular [Fan et al., 2012] - que envolvem a proliferação, diferenciação e inflamação celulares. Além de se relacionar com alguns genes (tais como: EGF/EGFR, AKT, GRB2 e FLNA) relevantes em esquizofrenia [Beaulieu et al., 2005; Sun et al., 2010], pois eles envolvem crescimento, transdução de sinal/comunicação celular e reorganização do citoesqueleto. A via de sinalização da neurotrofina relaciona-se com as vias de sinalização MAPK e apoptose, entre outras, e uma das funções da neurotrofina é impedir que os neurônios iniciem o processo de apoptose, permitindo com isso a sobrevivência dos neurônios. A via de sinalização ErbB, também já relacionada à esquizofrenia [Bennett, 2009; Paatero \& Elenius, 2008] foi relevante na nossa análise (ver Figuras C.1 e C.2). Observa-se que, além de se relacionar com vias importantes tais como: ciclo celular [Fan et al., 2012] e sinalização MAPK [Maycox et al., 2009], alguns genes hiper-representados (ErbB4, Src, Grb2, GSK-3) nessa via também são frequentemente associados à esquizofrenia [Bennett, 2009; Paatero \& Elenius, 2008; Salter \& Pitcher, 2011; Sun et al., 2010].

\subsubsection{O Conjunto (Grau $\cap X-$ Grau $\cap$ RWR)}

Na Seção 5.3.2, ao avaliarmos os 100 primeiros genes dos ranqueamentos obtidos pelo grau, $X$ e RWR, verificamos que dos 28 genes presentes no conjunto (Grau $\cap$ RWR), 27 estão presentes no conjunto $(\mathrm{Grau} \cap X)$, ou seja, apenas 1 está presente no primeiro conjunto que não está no segundo. Por outro lado, verificamos que o conjunto (Grau $\cap X)$ possui 43 genes dos quais 16 não foram encontrados no conjunto (Grau $\cap$ RWR). Assim, é natural investigar se há alguma relevância biológica nesses 16 genes encontrados pelo nosso método, mas que não foram encontrados pelo método RWR.

Neste ponto, lembramos que o escore $X$ visa encontrar genes co-expressos na vizinhança das sementes em uma ou ambas as condições (controle e doença). No método proposto, mesmo que a seleção dos caminhos mínimos dependa em grande parte da co-expressão dos genes com a semente, o escore $X$ tenderá também a priorizar genes de alto grau na vizinhança dos genes sementes, uma vez que ter um grau mais alto na vizinhança das sementes pode viabilizar a participação em muitos caminhos mínimos entre as sementes. Assim, o escore $X$ tende a alcançar genes altamente co-expressos e conectados na vizinhança das sementes, o que sugere que $X$ é apropriado para encontrar PARTY HUBS ${ }^{1}$ [Agarwal et al., 2010; Barabási et al., 2011]. Ao analisarmos as vias

\footnotetext{
${ }^{1}$ PARTY HUBS são altamente co-expressos com os seus parceiros, atuando como coordenadores locais.
} 
e processos biológicos desses 16 genes, descobrimos que a maioria deles ${ }^{1}$ está relacionada com esquizofrenia [Chen et al., 2013; Hashimoto et al., 2011; Kido et al., 2014; Pandey et al., 2015; Sinclair et al., 2012]. Isso sugere que o escore $X$ captura mais genes de alto grau relacionados com a doença do que o RWR. Outro aspecto a destacar em relação a tais interseções é que a partir de $N=480$ em diante, a interseção entre $X$ e o grau estabiliza, enquanto o RWR continua apresentando um contínuo aumento da interseção com o grau. Isso indica que o RWR é mais propenso ao viés da literatura (ascertainment bias).

Em relação às interseções de $\Delta^{\prime}$ e DADA com o grau, elas foram menores, o que sugere que essas pontuações são menos propensas ao viés da literatura. Além disso, é importante destacar que a classificação alcançada pelo DADA é fortemente baseada no ranqueamento do RWR, exceto pelo fato de que a primeira busca priorizar genes de baixo grau em certas condições. Lembrando que o $\Delta^{\prime}$ visa priorizar as diferenças de co-expressão (com as sementes) dos genes nos caminhos mínimos selecionados sob duas condições (controle e doença). Portanto, $\Delta^{\prime}$ é mais adequado para descobrir novos genes associados a uma determinada doença.

\subsection{Interseção dos estudos KATO, ALTARC e BAHN}

Todas as análises realizadas nas seções anteriores para os dados de expressão do estudo KATO, também foram realizadas para os dados de expressão dos estudos² ${ }^{2}$ ALTARC e BAHN. A aplicação do método ranqueando os genes pelo escore $\Delta^{\prime}$ para os 3 estudos diferentes (KATO, ALTARC e BAHN) produziu 3 listas de genes selecionados. Após a seleção de aproximadamente $10 \%$ dos genes mais diferencialmente alterados (de maior $\Delta^{\prime}$ ) em cada lista, obtivemos uma lista de interseção com 129 genes, que foi utilizada nas análises de GO e KEGG. É importante lembrar que os 3 estudos inicialmente não possuíam quase nenhuma interseção entre seus genes diferencialmente expressos, mas após a aplicação do nosso método conseguimos obter uma interseção de 46,9\% (129 genes / 275 genes) entre as listas dos 10\% melhores genes ranqueados por $\Delta^{\prime}$. Após analisarmos os resultados desses 129 genes verificamos que a grande maioria deles está presente nas mesmas vias hiper-representadas resultantes do método aplicado individualmente ao estudo KATO (apresentados na Seção 6.1.1). Nesta seção, apresentamos a análise biológica desses 129 genes pertencentes a interseção entre os estudos KATO, ALTAR e BAHN, relativos aos ranqueamentos do escore $\Delta^{\prime}$ - conforme descrito anteriormente (parâmetros utilizados: $\epsilon=0.05, X_{\text {ini }}=5$ e percentual $=10 \%)$.

\subsubsection{Ranqueamento $\Delta^{\prime}$}

\section{Análise GO}

A Figura B.3 apresenta respectivamente a distribuição desses 129 genes em suas respectivas categorias de processos biológicos - através de um grafo acíclico de análise GO. Observa-se que os processos biológicos pela interseção dos resultados do método aplicado aos 3 estudos, são os

${ }^{1}$ NR3C1, GABARAPL1, UBC, TRAF6, APP, YWHAQ, EPB41, CTNNB1, MAPK1, IKBKG, PIK3R1, IKBKE, HSP90AA1, MDM2, RELA e ATF2.

${ }^{2}$ Obtidos no banco de dados SNCID (Kim \& Webster [2010]). 
mesmos que os resultados do método quando aplicado individualmente ao estudo KATO, e isto indica que o método está alcançando replicabilidade nos resultados.

\section{Análise KEGG}

Além disso, realizamos uma análise de enriquecimento KEGG neste conjunto de 129 genes. Como esperado, o processo biológico e análise de enriquecimento KEGG (com mais de 10 genes em cada categoria e um P-valor ajustado $<0,01$ ) foram semelhantes a análise anterior (ver Figura 6.1 na Seção 6.1.1), uma vez que todos esses 129 genes também estão contidos na lista de 265 genes obtidos a partir do estudo KATO. Entretanto, vale ressaltar que na primeira análise (Seção 6.1.1), nada específico relacionado a neurônios apareceu com critérios tão rigorosos, mas usando os 129 genes na análise de enriquecimento de componente celular, as projeções de neurônios ( $\operatorname{adjP}=$ 8,3e-19) apresentadas na Tabela D.1 (Apêndice D) foram hiper-representadas [Glausier \& Lewis, 2013].

Outro ponto importante é que a análise de enriquecimento de doença a partir dos 129 genes também apresentou câncer, estresse, distúrbios neuro-degenerativos e outros distúrbios psiquiátricos. Interessante notar que, embora outros distúrbios psiquiátricos tais como a depressão e Alzheimer também apareceram hiper-representados além da esquizofrenia na análise dos 129 genes, considerando-se os mesmos critérios em ambas as análises, a maioria dos distúrbios psiquiátricos que apareceram hiper-representados na análise KATO (transtorno do pânico e transtorno alimentar) não apareceram com os 129 genes da lista de interseção (ver Tabela D.1 - Apêndice D). Existe uma alta comorbidade entre transtornos psiquiátricos e vários genes são compartilhados por mais de uma doença, porém na análise dos 129 genes, transtornos psiquiátricos mais comumente associados a esquizofrenia foram encontrados (como depressão) [Archer et al., 2014; Samsom \& Wong, 2015].

Procuramos por módulos PPI humanos hiper-representadas nos 129 genes (interseção dos ranqueamentos $\Delta^{\prime}$ dos 3 estudos) e encontramos 5 módulos PPI, conforme mostrados na Figura 6.3. As funções relacionadas a estes módulos são apresentadas na Figura 6.4. O módulo mais interessante foi o Módulo 26 (adjp = 0,0021) com 14 genes hiper-representados em nossa lista e oriundos do conjunto de 129 genes. Este módulo está relacionado com a via de sinalização do receptor de glutamato, uma via muito importante relacionada à esquizofrenia [Iasevoli et al., 2014].

A Figura 6.5 representa o Módulo PPI 26 do interatoma Humano (ferramentas de rede WebGestalt). Nós verdes representam genes pertencentes ao conjunto dos 129 genes. É importante notar que Macdonald et al. [2014], ao comparar casos e controles de esquizofrenia, porém buscando proteínas diferencialmente expressas, chegou em alterações do módulo glutamatérgico e em proteínas também relatadas por nós. Concluímos com a nossa análise biológica que o nosso método é capaz de selecionar genes já relacionados com a esquizofrenia (pela utilização do escore $X$ ), bem como apontar novos genes e caminhos que podem fornecer bons candidatos (pela utilização do escore $\Delta^{\prime}$ ). Também observamos que o nosso método atinge uma grande sobreposição $(46,9 \%)$ entre os diferentes estudos que, usando apenas os métodos convencionais que realizam análises de expressão diferencial, alcançavam praticamente interseção nula entre as listas resultantes. Assim, além de alcançar uma concordância razoável entre os estudos, o método também foi capaz de 


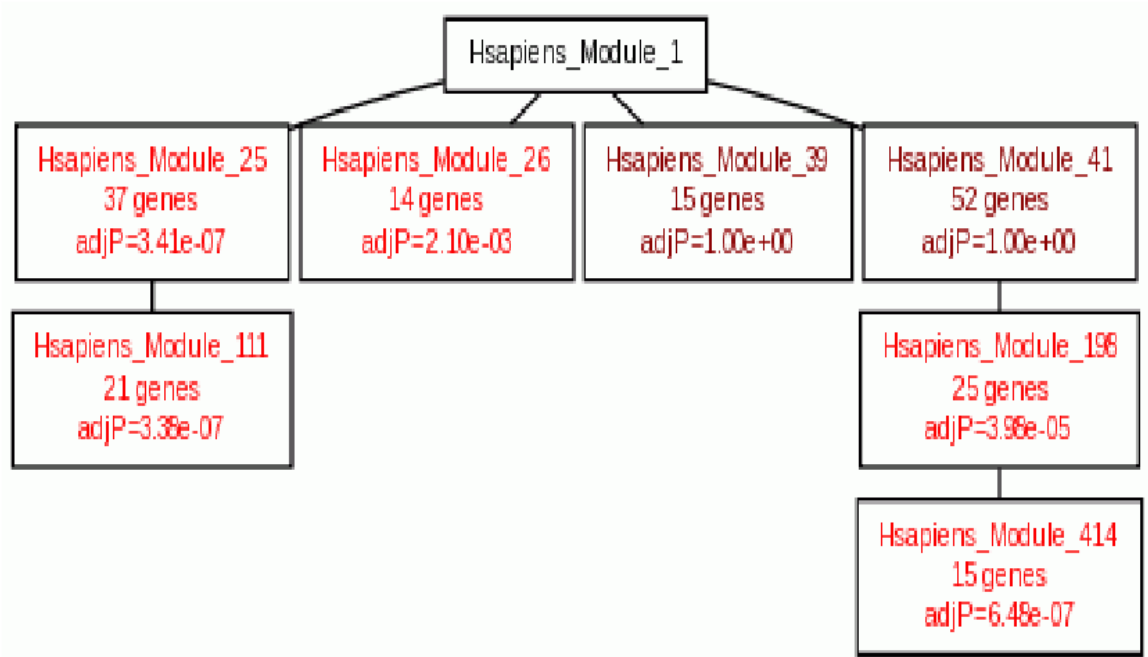

Figura 6.3: Módulos PPI humanos hiper-representados nos 129 genes.

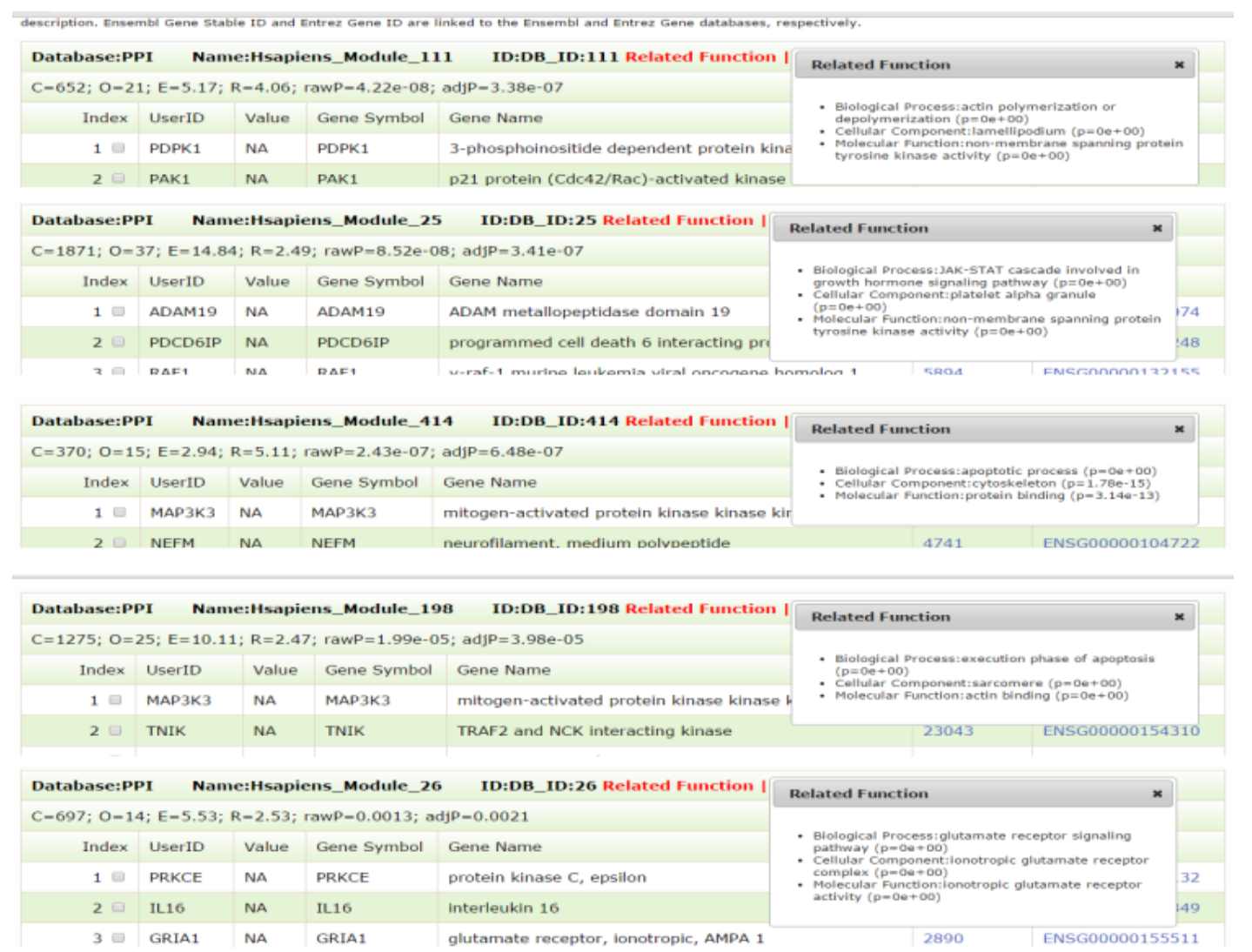

Figura 6.4: Funções relacionadas aos módulos PPI humanos hiper-representados apresentados na Figura 6.3. Destaque para o módulo 26 que está relacionado ao receptor de glutamato. 


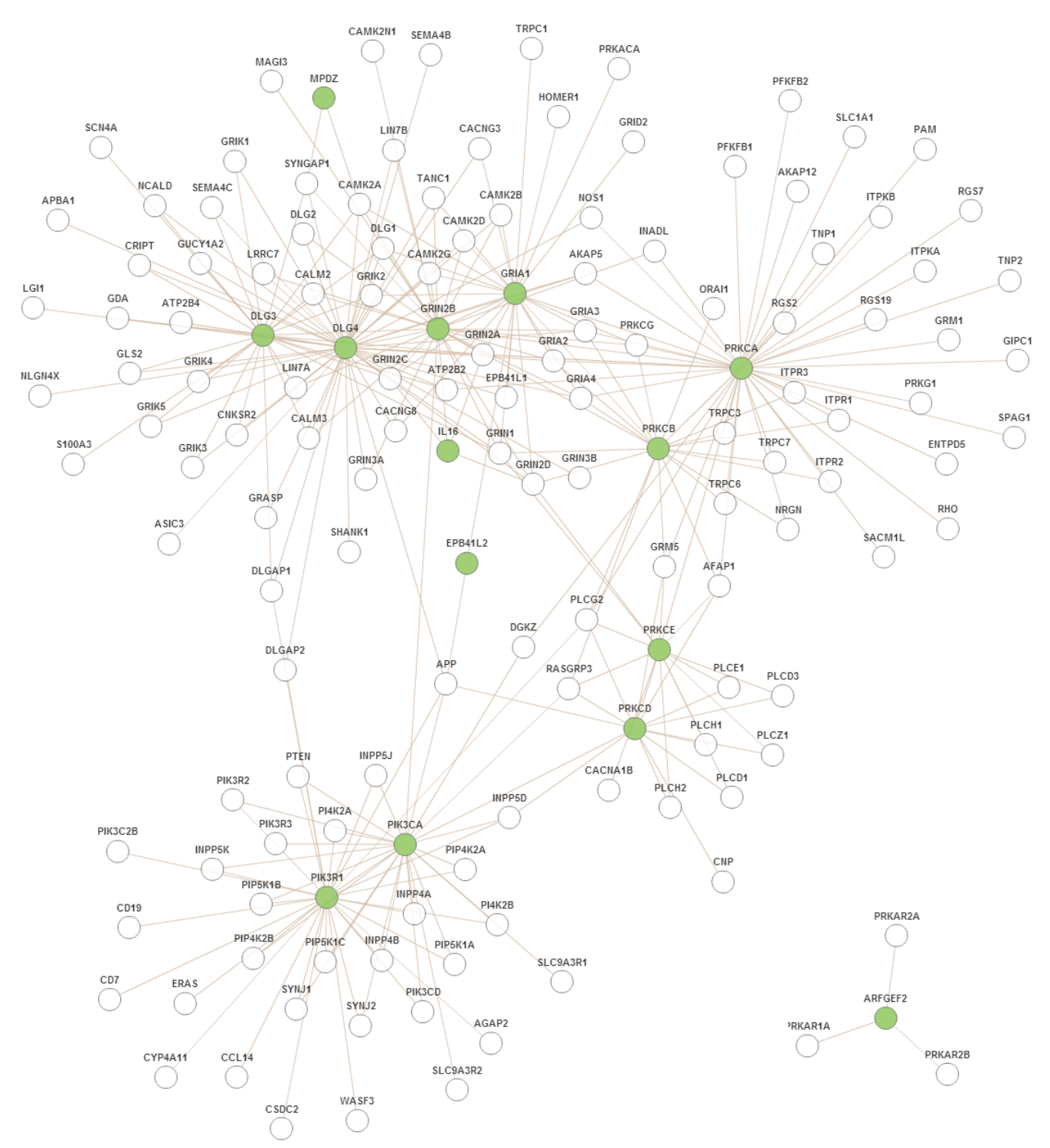

Figura 6.5: Módulo 26 com 14 genes (nós verdes) pertencentes aos 129 genes da interseção dos estudos KATO, ALTARC, and BAHN. Este módulo está relacionado com a via de sinalização do receptor de glutamato, uma via muito importante relacionada à esquizofrenia.

selecionar um conjunto mais restrito de genes relacionados com uma doença complexa específica.

\subsection{Desempenho do Método}

Grande parte do método proposto foi implementado em Python utilizando as bibliotecas Numpy e SciPy juntamente com o pacote de redes NetworkX (Hagberg et al. [2008]) - algumas funções ${ }^{1}$ desenvolvidas nesse trabalho, necessárias à implementação do método, foram disponibilizadas como software livre e em meados de agosto de 2012 passaram a integrar o pacote NetworkX. O método foi aplicado a uma rede com 9.554 nós (genes) e 61.998 arestas (interações) para analisar todos os 157.638 caminhos mínimos possíveis entre 30 nós sementes e 781 nós da vizinhança,

\footnotetext{
${ }^{1}$ Algumas delas: all_shortest_paths, all_simple_paths, entre outras.
} 
selecionando 23.430 caminhos mínimos através do coeficiente de concordância de Kendall. Isto foi realizado para os dados de expressão de controle e doença, e demorou aproximadamente 35 minutos (usando apenas um processador) em um computador Intel Xeon (X5650) 2.67GHz e 24GB de memória. Para aumentar o desempenho, foram realizadas algumas otimizações nas funções mais críticas, sendo que uma das técnicas principais utilizadas para o aumento do desempenho foi a memoização - armazenar cálculos intermediários (que serão repetidos muitas vezes) para serem utilizados posteriormente. 



\section{Capítulo 7}

\section{Conclusões}

Neste trabalho, desenvolvemos uma nova metodologia de integração de dados que modela as hipóteses da Network Medicine para para explorar e destacar genes potencialmente relacionados a doenças complexas. A metodologia consiste em 3 etapas: (i) integração de dados, (ii) cálculo da importância relativa e (iii) seleção de genes - através de análise diferencial entre duas condições controle e doença. Para integrar os dados, o método mapeia as proteínas e os dados de expressão de transcritos em uma base comum e, para isso, ambos foram mapeados em seus respectivos genes de origem. Após a integração de dados, assumindo algumas hipóteses da Network Medicine (localidade, módulo de doença e parcimônia da rede), o método explora a vizinhança de um conjunto de genes sementes pela seleção de caminhos mínimos que possuem genes mais co-expressos. Como normalmente há diversos caminhos mínimos para cada par de genes, propomos um critério de seleção (baseado no coeficiente de concordância de Kendall) para selecionar caminhos potencialmente mais relevantes.

Todo o processo é realizado usando dados de expressão em duas condições (controle e doença) separadamente. Portanto, ao final são gerados dois valores de importância relativa para cada gene, uma relativa a expressão da doença e outra a expressão do controle. Em seguida, o método proposto utiliza estes dois valores de importância relativa (um em cada condição) para produzir como saída dois escores (ou pontuações) finais: $X$ e $\Delta^{\prime}$. O primeiro $(X)$ prioriza genes que possuem características de party hubs possuindo, ao mesmo tempo, alta centralidade topológica e elevada co-expressão em relação aos genes sementes. O segundo $\left(\Delta^{\prime}\right)$ prioriza os genes mais alterados entre as duas condições (controle e doença).

Para construção da rede PPI foram utilizados dados dos bancos HPRD, Mint e IntAct. Escolhemos esquizofrenia como estudo de caso para validar o método, sendo que os dados de expressão de esquizofrenia adotados foram provenientes de 3 estudos diferentes (KATO, ALTARC e BAHN). Os dados de estudos de associação (GWAS) utilizados para definir os genes sementes foram os core genes de Jia et al. [2010].

\subsection{Resultados Alcançados}

Uma das contribuições mais importantes deste trabalho foi a melhoria na replicação dos resultados encontrados pelo método ao ser aplicado em 3 estudos diferentes de esquizofrenia (KATO, 
ALTAR e BAHN). Métodos convencionais (como diferença de expressão) não alcançavam replicabilidade entre os estudos. Mas o método proposto alcançou uma replicabilidade de $46 \%$ para o escore $\Delta^{\prime}$ e $70 \%$ para o escore $X$ - ao selecionar genes importantes dos 3 diferentes estudos de microarranjos da mesma doença, produzindo um conjunto de genes mais específicos relacionados com o transtorno estudado. Além disso, desenvolvemos um novo método para cálculo da importância relativa que leva em consideração não apenas fatores topológicos na rede PPI, mas também a expressão gênica. Também realizamos uma adaptação no coeficiente de concordância de Kendall para selecionar caminhos mínimos entre dois genes na rede PPI, independentemente da regulação entre os genes ser positiva ou negativa.

Através de algumas ferramentas de análises biológicas (WebGestalt: GO e KEGG, análise de doença, etc) constatamos que os genes obtidos pelo escore $\Delta^{\prime}$ pertencem a vias hiper-representadas relacionadas a esquizofrenia, e que o escore $X$ identificou genes bastante conhecidos na literatura associados à doença. Realizamos uma análise comparativa envolvendo o nosso método e dois métodos do estado da arte (RWR e DADA). Os resultados mostraram que o nosso método (escores $X$ e $\Delta$ ) complementa os métodos RWR e DADA pela obtenção de genes que apresentam um bom equilíbrio entre a centralidade topológica (em relação aos genes sementes) e a co-expressão diferencial de genes em duas condições. Adicionalmente, de forma semelhante ao DADA, o escore $\Delta^{\prime}$ não apresenta o problema do viés da literatura (ascertainment bias).

Por um lado, o escore $\Delta^{\prime}$ priorizou genes pertencentes a vias biológicas altamente relacionados à esquizofrenia, indicando que essa pontuação poderia ser utilizada para a descoberta de novos genes relacionados à doença (gene discovering). Por outro lado, o escore $X$ priorizou genes relacionados à esquizofrenia que são bastante conhecidos pela literatura. Portanto, por integrar coexpressão gênica com rede PPI, o nosso método alcança resultados mais específicos e restritivos que podem permitir a descoberta de genes. Vale ainda destacar o excelente desempenho computacional do método proposto, que demorou menos de uma hora para fazer todo o processamento.

\subsection{Trabalhos Futuros}

Dentre os trabalhos futuros a serem desenvolvidos, podemos destacar:

1. Aplicar o método a outras doenças complexas, tais como: Autismo, Alzheimer, Hipertensão e Diabetes.

2. Analisar os resultados obtidos também para as interações - além das análises geradas para os genes - verificando se esta análise pode ajudar a identificar vias biológicas mais promissoras.

3. Integrar mais dados ao método, tais como dados de tecido e epigenética, intencionando obter resultados ainda mais específicos. 


\section{Apêndice A}

\section{Categorias de processos biológicos}

\section{A.1 Ranqueamento $\Delta^{\prime}$}

A distribuição destes genes em suas respectivas categorias de processos biológicos é apresentada na Figura A.1. Entre os processos biológicos podemos destacar: regulação biológica (213 genes), resposta ao estímulo (194 genes), comunicação celular (163 genes), processo de desenvolvimento (141 genes), morte celular (79 genes), proliferação celular (71 genes). Esta análise realizada para o conjunto dos primeiros genes classificados pelo escore $\Delta^{\prime}$ para dados de expressão do estudo KATO, também foi realizada para os demais estudos ALTARC e BAHN, e apresentou resultados semelhantes - obtendo genes relacionados às mesmas vias e processos biológicos.

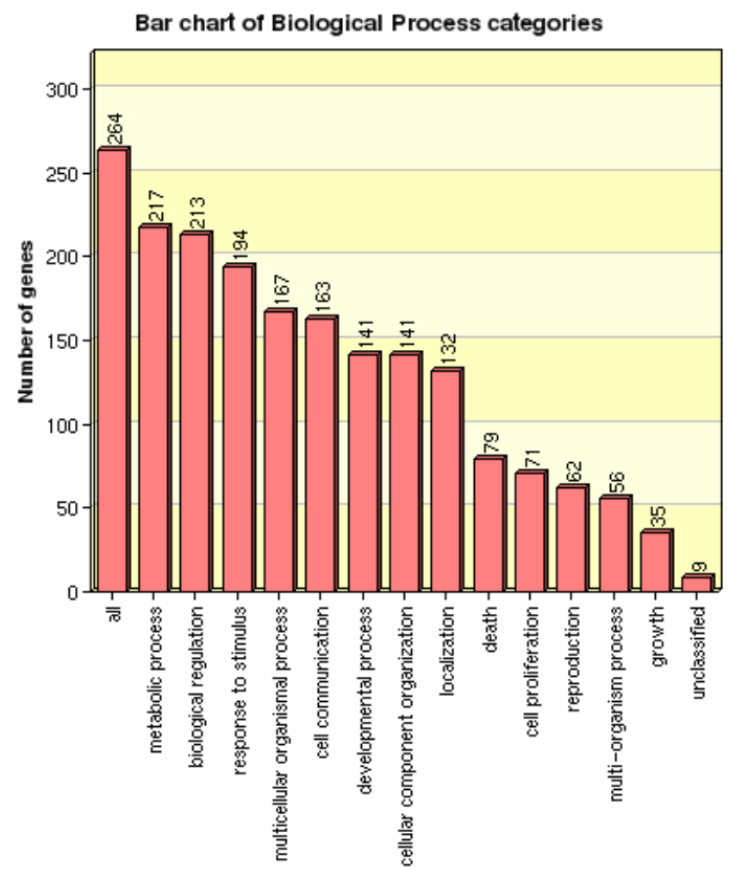

Figura A.1: Distribuição dos genes nas categorias de processos biológicos. Após a aplicação do método, utilizamos os $10 \%$ melhores genes ranqueados por $\Delta^{\prime}$ aplicado ao estudos KATO - (parâmetros utilizados: $\epsilon=0.05, X_{\text {ini }}=5$ e percentual $=$ 10\%). Podemos destacar os seguintes processos: comunicação celular, morte celular (apoptose), regulação biológica, resposta ao estímulo, proliferação celular (capacidade de neurogênese). 


\section{A.2 Ranqueamento $X$}

A Figura A.2 apresenta as categorias de processos biológicos e observamos que o escore $X$ encontrou vias semelhantes ao escore $\Delta^{\prime}$ (apresentado na Figura A.1). Em particular, entre os processos biológicos apresentados na Figura A.2, podemos destacar: regulação biológica (232 genes), resposta ao estímulo (209 genes), comunicação celular (187 genes), processo de desenvolvimento (174 genes), morte celular (108 genes), proliferação celular (82 genes). A mesma análise dos resultados obtidos pelo escore $X$ foi realizada para os demais estudos ALTARC e BAHN e apresentou resultados semelhantes.

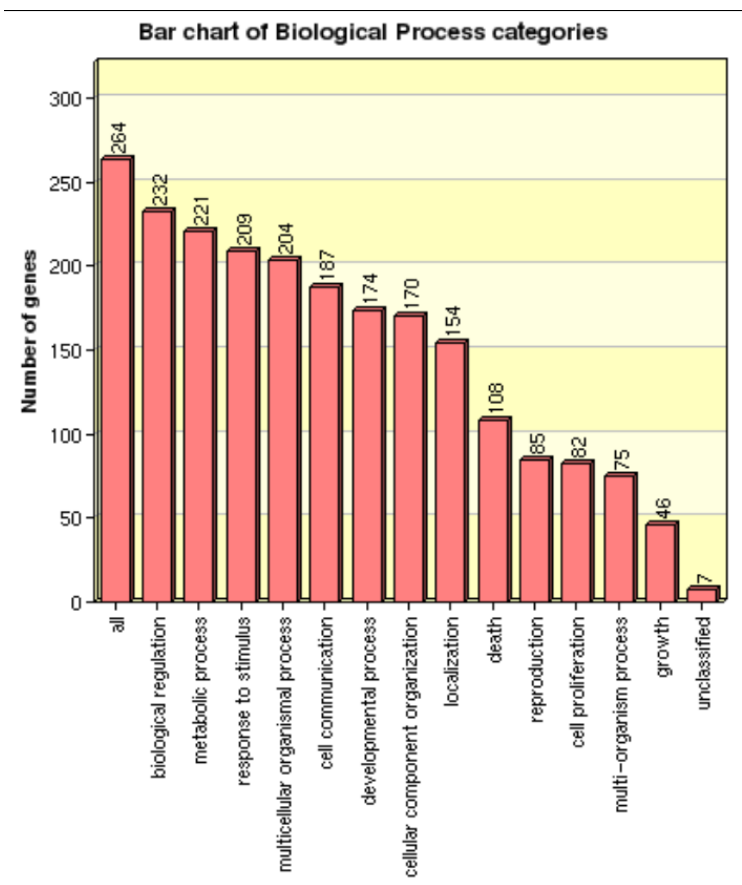

Figura A.2: Distribuição dos genes nas categorias de processos biológicos dos $10 \%$ melhores genes ranqueados por $X$ - referentes ao estudos KATO (parâmetros utilizados: $\epsilon=0.05, X_{i n i}=5$ e percentual $=10 \%$ ).

\section{A.3 Interseção dos estudos KATO, ALTARC e BAHN}

Primeiramente, verificamos a distribuição desses 129 genes em suas respectivas categorias de processos biológicos, conforme apresentado na Figura A.3. Observamos que as categorias de processos biológicos em que os genes estão distribuídos são praticamente as mesmas do estudo KATO (apresentado na Seção 6.1.1): regulação biológica (112 genes), resposta ao estímulo (100 genes), comunicação celular (93 genes), processo de desenvolvimento (85 genes), morte celular (54 genes), proliferação celular (45 genes) - apesar de estar sendo utilizados somente 129 genes, ao invés dos 265 usados na análise anterior. 


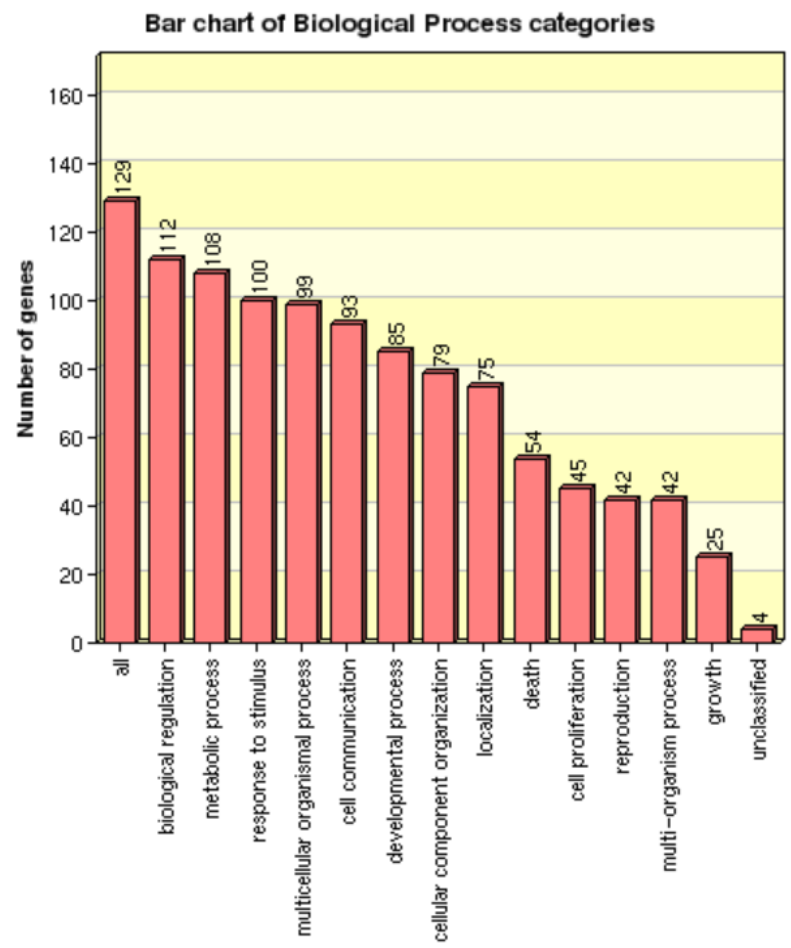

Figura A.3: Distribuição dos 129 genes da interseção nas categorias de processos biológicos. Os genes foram selecionados após a aplicação do método e foram obtidos através da interseção entre os resultados do escore $\Delta^{\prime}$ aplicado aos estudos KATO, ALTAR e BAHN - conforme descrito anteriormente (parâmetros utilizados: $\epsilon=0.05, X_{\text {ini }}=5$ e percentual $=10 \%$ ). 
Apêndice B

Análises GO 


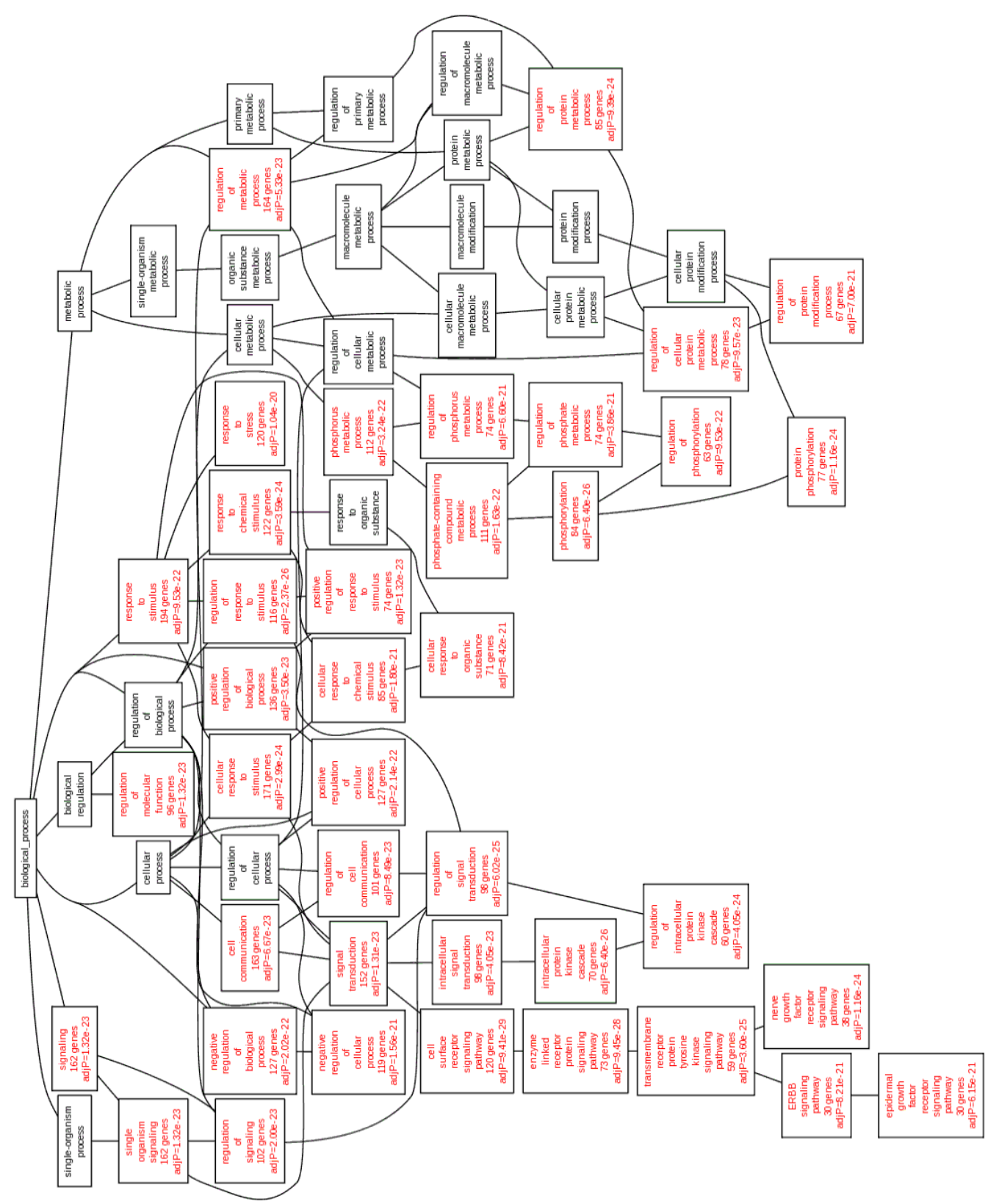

Figura B.1: AnÁlise GO (RANQUEAMEnto $\Delta^{\prime}$, estudo KATO):

Representação das categorias dos processos biológicos GO dos $10 \%$ (265) melhores genes do ranqueamento $\Delta^{\prime}$ relativo ao estudo KATO. Podemos destacar algumas categorias relacionadas à esquizofrenia: desenvolvimento celular, comunicação celular, transdução de sinal, regulação da comunicação celular, regulação da transdução de sinal. 


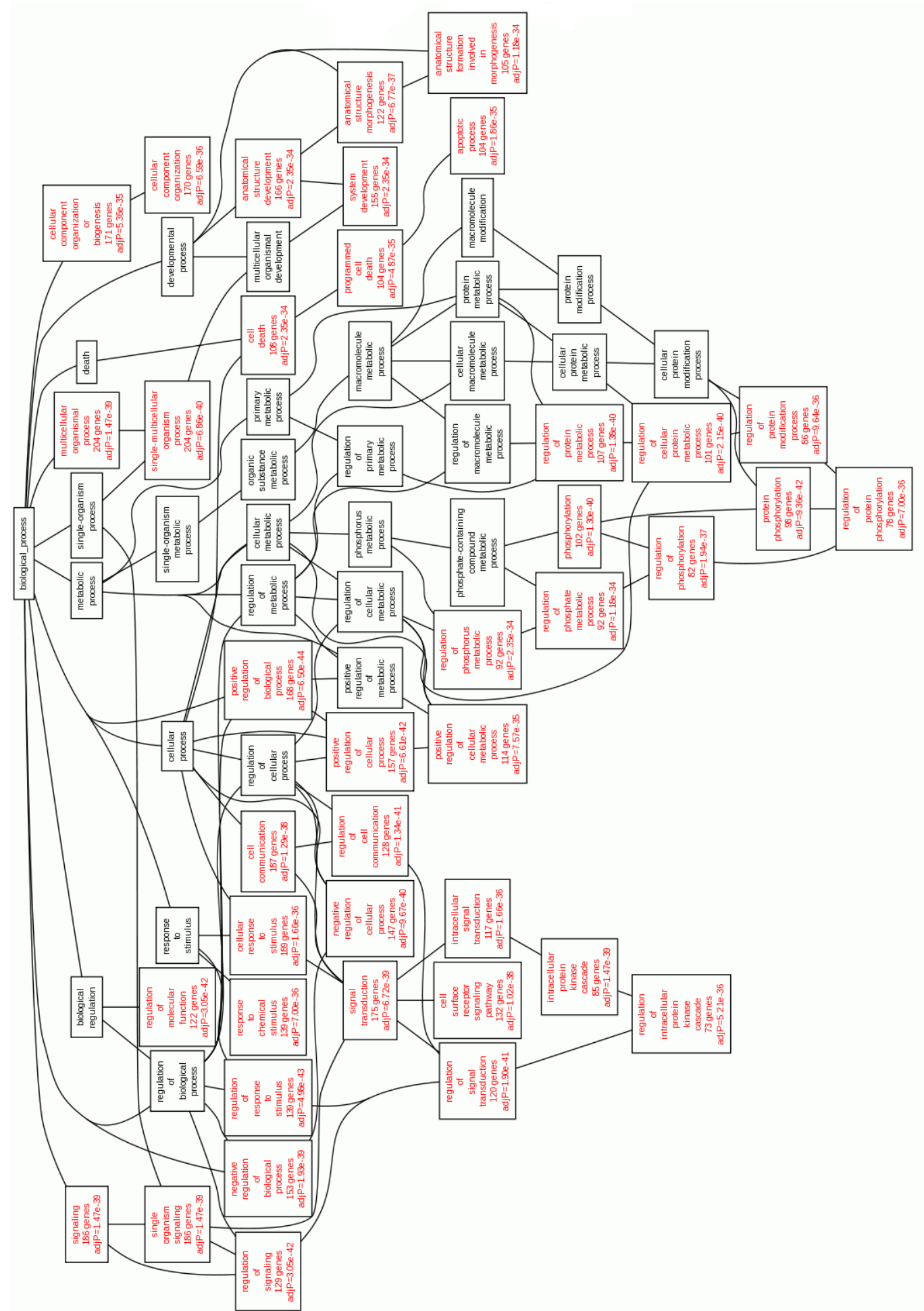

Figura B.2: Análise GO (RANqueAmento $X$, estudo KATO):

Representação das categorias dos $10 \%$ (265) melhores genes do ranqueamento $X$ relativo ao estudo KATO. Similarmente à Figura B.1, podemos destacar algumas categorias relacionadas à esquizofrenia: desenvolvimento celular, comunicação celular, transdução de sinal, regulação da comunicação celular, regulação da transdução de sinal. 


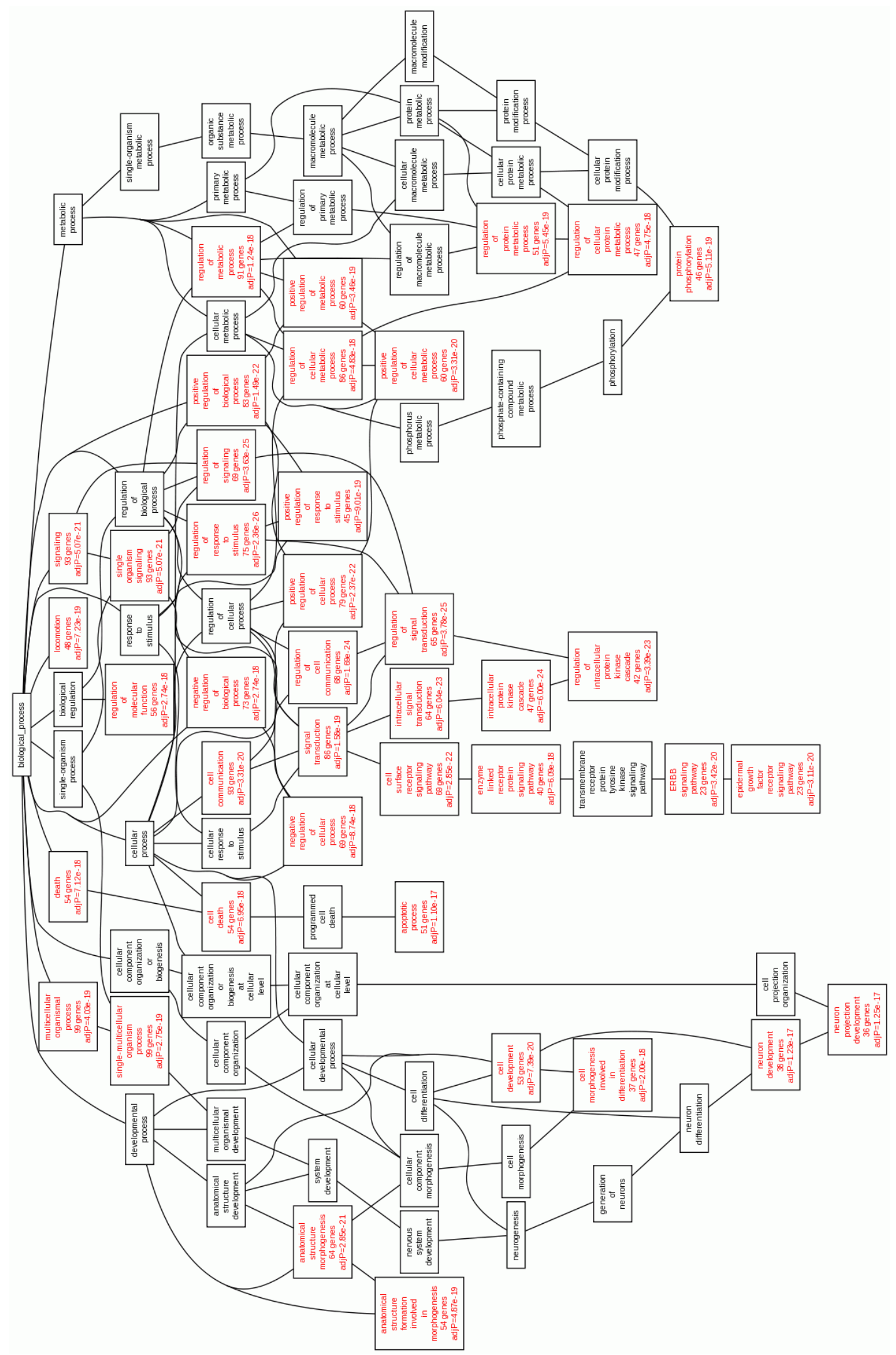

Figura B.3: AnÁlise GO (RANQueAmento $\Delta^{\prime}$, InTERSEÇão ENTRE os 3 ESTUdos):

Os genes foram selecionados após a aplicação do método e foram obtidos através da interseção entre os resultados do escore $\Delta^{\prime}$ aplicado aos estudos KATO, ALTAR e BAHN - conforme descrito anteriormente (parâmetros utilizados: $\epsilon=0.05, X_{\text {ini }}=5$ e percentual $=10 \%$ ). 
Apêndice C

Análises KEGG 


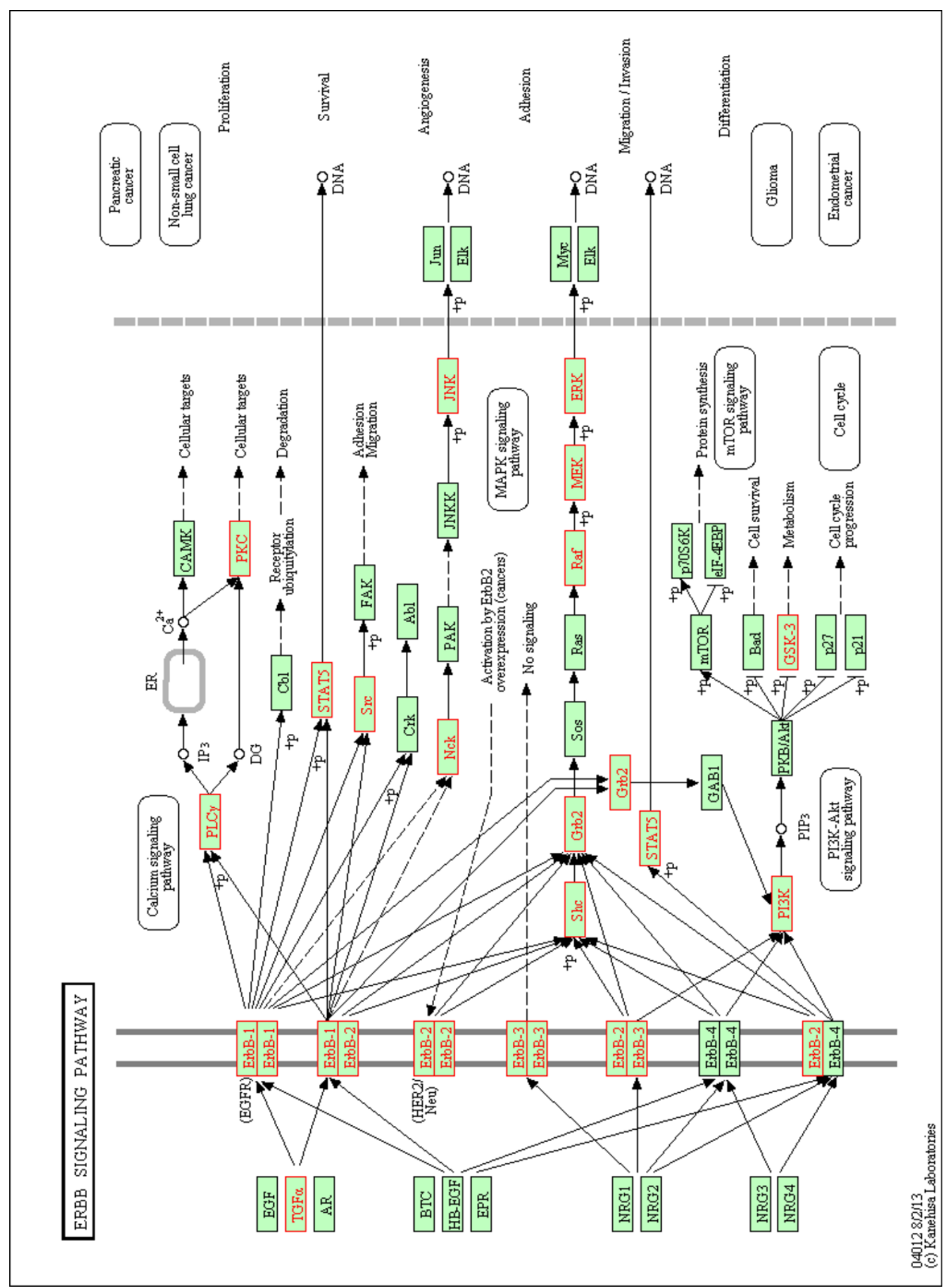

Figura C.1: KEGG-via de sinalização ErbB para os 10\% (265) melhores genes ranqueados pelo escore $\Delta^{\prime}$ para o estudo KATO. 


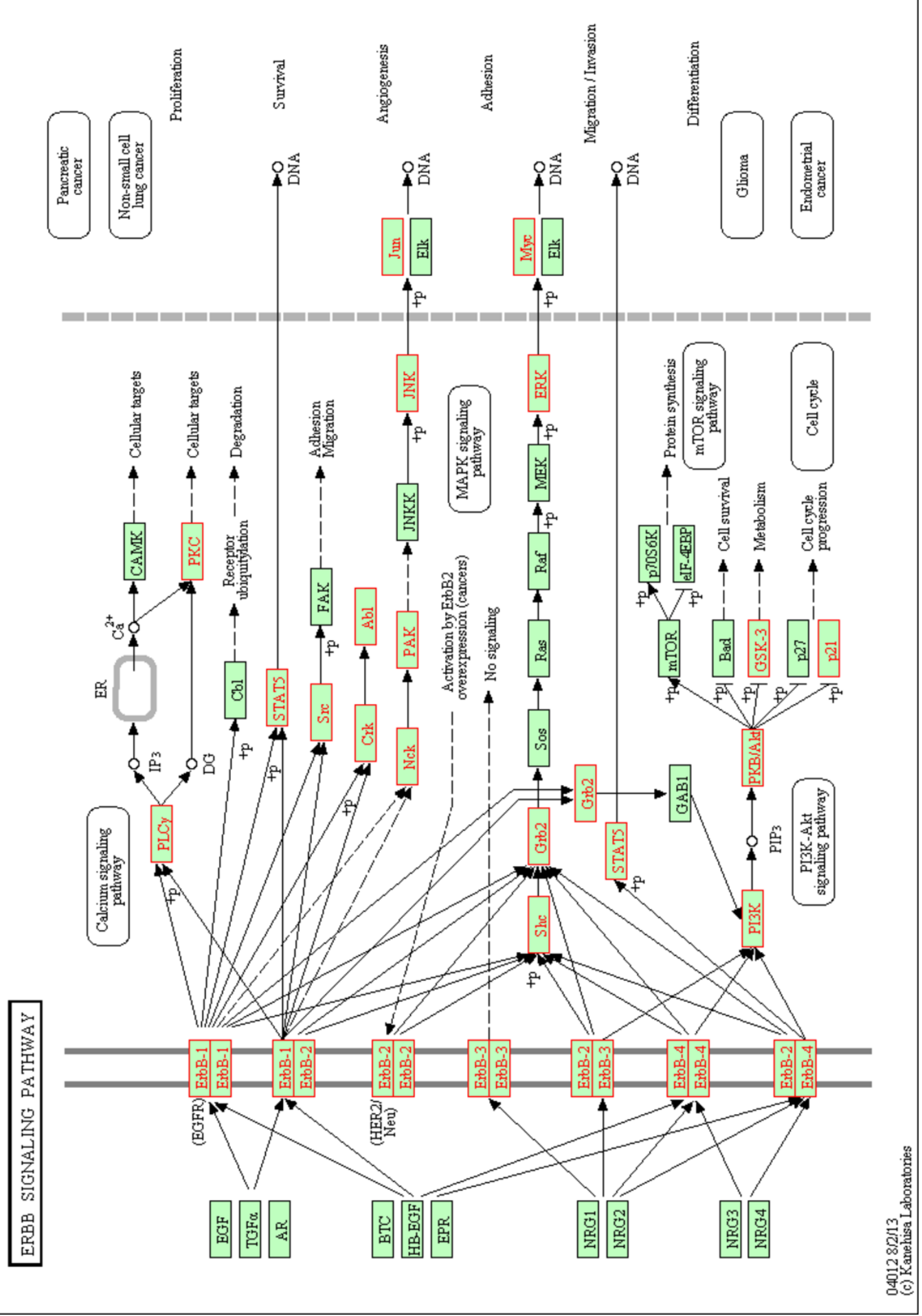

Figura C.2: KEGG-via de sinalização ErbB para os 10\% (265) melhores genes ranqueados pelo escore $X$ para o estudo KATO. Observamos diversos genes importantes associados à esquizofrenia (ErbB4, Src, Grb2, GSK-3) pertencentes a via e que foram encontrados pelo escore $X$, de maneira similar ao resultado encontrado pelo escore $\Delta^{\prime}$ apresentado na Figura C.1. 

Apêndice D

Projeção de Neurônios - Análise de Componente Celular 


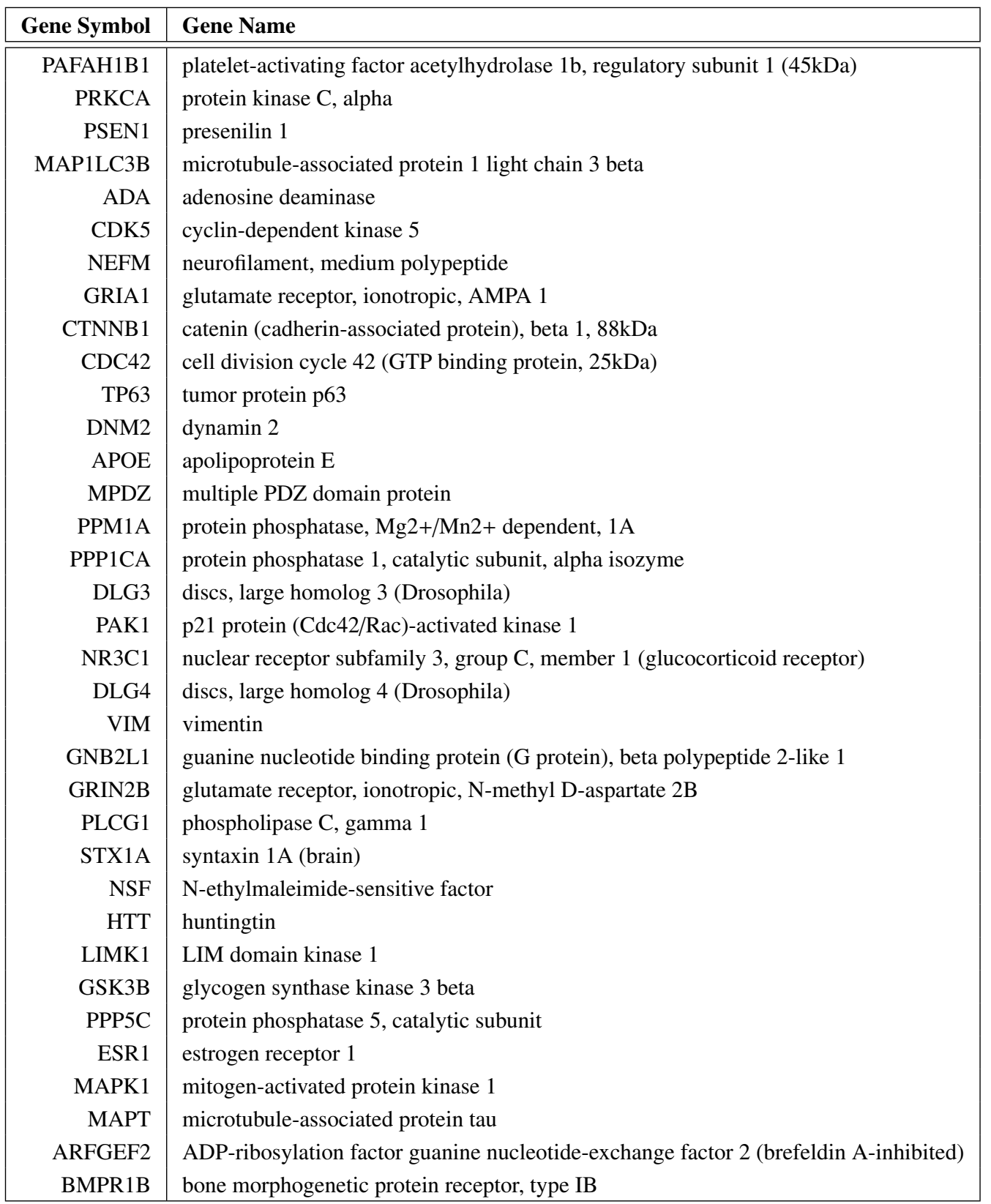

Tabela D.1: Análise de enriquecimento da componente celular: projeções de neurônios. Genes enriquecidos obtidos da lista dos 129 genes da interseção dos estudos (KATO, ALTARC e BAHN) após o ranqueamento $\Delta^{\prime}$. Parâmetros utilizados: Database:cellular component; Name:neuron projection; ID:GO:0043005; $C=651 ; O=35 ; E=4.89 ; R=7.16 ;$ raw $P=1.08 \mathrm{e}-20 ; \operatorname{adjP}=8.32 \mathrm{e}-19$. 


\section{Referências Bibliográficas}

Agarwal, S., Deane, C. M., Porter, M. A. \& Jones, N. S. (2010). Revisiting date and party hubs: Novel approaches to role assignment in protein interaction networks. PLoS Computational Biology 6(6), 1-12.

Aittokallio, T. \& Schwiкowsкi, B. (2006). Graph-based methods for analysing networks in cell biology. Briefings in bioinformatics 7(3), 243-55.

Archer, T., Ricci, S., Garcia, D. \& Ricciardi, M. R. (2014). Neurodegenerative aspects in vulnerability to schizophrenia spectrum disorders.

Barabási, A.-L., Gulbahce, N. \& Loscalzo, J. (2011). Network medicine: a network-based approach to human disease. Nature reviews. Genetics 12(1), 56-68.

Barrenas, F., Chavali, S., Holme, P., Mobini, R. \& Benson, M. (2009). Network properties of complex human disease genes identified through genome-wide association studies. PloS one 4(11), e8090.

Beaulieu, J. M., Sotnikova, T. D., Marion, S., Lefkowitz, R. J., Gainetdinov, R. R. \& Caron, M. G. (2005). An akt $/ \beta$-arrestin 2/pp2a signaling complex mediates dopaminergic neurotransmission and behavior. Cell 122(2), 261-273.

Bennett, M. (2009). Positive and negative symptoms in schizophrenia: the nmda receptor hypofunction hypothesis, neuregulin/erbb4 and synapse regression. The Australian and New Zealand journal of psychiatry $\mathbf{4 3}(8), 711-21$.

Bolstad, B. M., Irizarry, R. A., Astrand, M. \& Speed, T. P. (2003). A comparison of normalization methods for high density oligonucleotide array data based on variance and bias. Bioinformatics (Oxford, England) 19(2), 185-93.

Cai, J. J., Borenstein, E. \& Petrov, D. A. (2010). Broker genes in human disease. Genome biology and evolution 2, 815-25.

Chen, D.-B., Gao, H., LÜ, L. \& Zhоu, T. (2013). Identifying influential nodes in large-scale directed networks: the role of clustering. PloS one 8(10), e77455.

Chen, J., Aronow, B. J. \& Jegga, A. G. (2009). Disease candidate gene identification and prioritization using protein interaction networks. BMC bioinformatics 10, 73. 
Chо, Y.-R. \& Zhang, A. (2010). Identification of functional hubs and modules by converting interactome networks into hierarchical ordering of proteins. BMC bioinformatics 11 Suppl 3(Suppl 3), S3.

Chunng, J. S. \& Roth, D. (2001). Gene recognition based on dag shortest paths. Bioinformatics (Oxford, England) 17 Suppl 1, S56-64.

Cookson, W., Liang, L., Abecasis, G., Moffatt, M. \& Lathrop, M. (2009). Mapping complex disease traits with global gene expression. Nature reviews. Genetics 10(3), 184-94.

Davey Smith, G., Ebrahim, S., Lewis, S., Hansell, A. L., Palmer, L. J., Burton, P. R. \& Smith, G. D. (2005). Genetic epidemiology and public health: hope, hype, and future prospects. Lancet 366(9495), 1484-98.

Debnath, M., Venkatasubramanian, G. \& Berk, M. (2015). Fetal programming of schizophrenia: Select mechanisms. Neuroscience $\mathcal{E}$ Biobehavioral Reviews 49, 90-104.

Dijkstra, E. W. (1959). A note on two problems in connexion with graphs. Numerische Mathematik 1, 269-271.

Dudoit, S., Yang, Y. H., Callow, M. J. \& Speed, T. P. (2002). Statistical methods for identifying differentially expressed genes in replicated cdna microarray experiments. Statistica sinica 12(3), $111-139$.

Edwards, A. M., Kus, B., Jansen, R., Greenbaum, D., Greenblatt, J. \& Gerstein, M. (2004). Bridging structural biology and genomics: assessing protein interaction data with known complexes. Drug discovery today $\mathbf{9}$ (2 Suppl), S32-40.

EpPsteIn, D. (1998). Finding the k shortest paths. SIAM Journal on computing , 1-26.

Erten, S., Bebek, G., Ewing, R. M. \& Koyutürk, M. (2011). Dada: Degree-aware algorithms for network-based disease gene prioritization. BioData mining $\mathbf{4}(1), 19$.

Fan, Y., Abrahamsen, G., McGrath, J. J. \& Mackay-Sim, A. (2012). Altered cell cycle dynamics in schizophrenia. Biological psychiatry 71(2), 129-35.

FLoyd, R. R. W. (1962). Algorithm 97: Shortest path. Communications of the ACM , 345.

Franke, L., van Bakel, H., Fokkens, L., de Jong, E. D., Egmont-Petersen, M. \& Wijmenga, C. (2006). Reconstruction of a functional human gene network, with an application for prioritizing positional candidate genes. American journal of human genetics 78(6), 1011-25.

Gaiteri, C., Ding, Y., French, B., Tseng, G. C. \& Sibille, E. (2014). Beyond modules and hubs: The potential of gene coexpression networks for investigating molecular mechanisms of complex brain disorders. Genes, Brain and Behavior 13(1), 13-24.

Gassó, P., Mas, S., Molina, O., Lafuente, A., Bernardo, M. \& Parellada, E. (2014). Increased susceptibility to apoptosis in cultured fibroblasts from antipsychotic-naïve first-episode schizophrenia patients. Journal of Psychiatric Research 48(1), 94-101. 
Gilad, Y., Rifkin, S. A. \& Pritchard, J. K. (2008). Revealing the architecture of gene regulation: the promise of eqtl studies. Trends in genetics : TIG 24(8), 408-15.

Glausier, J. R. \& Lewis, D. A. (2013). Dendritic spine pathology in schizophrenia.

Goн, K.-I. \& Chо, I.-G. (2012). Exploring the human diseasome: the human disease network. Briefings in functional genomics 11(6), 533-42.

Goh, K.-I., Cusick, M. E., Valle, D., Childs, B., Vidal, M. \& Barabási, A.-L. (2007). The human disease network. Proceedings of the National Academy of Sciences of the United States of America 104(21), 8685-90.

Hagberg, A. A., Schult, D. A., Swart, P. J., Alamos, L., World, S. \& Graph, W. (2008). Exploring network structure, dynamics, and function using networkx. In: Proceedings of the 7th Python in Science Conference (SciPy2008), SciPy. Pasadena, CA USA.

Han, J.-D. J., Bertin, N., Hao, T., Goldberg, D. S., Berriz, G. F., Zhang, L. V., Dupuy, D., WaLhout, A. J. M., Cusick, M. E., Roth, F. P. \& Vidal, M. (2004). Evidence for dynamically organized modularity in the yeast protein-protein interaction network. Nature 430(6995), 8893.

Hart, G. T., Ramani, A. K. \& Marcotte, E. M. (2006). How complete are current yeast and human protein-interaction networks? Genome biology 7(11), 120.

Hashimoto, R., Оhi, K., Yasuda, Y., Funumoto, M., Yamamori, H., Takahashi, H., Iwase, M., Окоснi, T., Kazui, H., Saitoh, O., Tatsumi, M., Iwata, N., Ozaki, N., Kamijima, K., Kunugi, H. \& TAKEDA, M. (2011). Variants of the rela gene are associated with schizophrenia and their startle responses. Neuropsychopharmacology : official publication of the American College of Neuropsychopharmacology 36(9), 1921-1931.

Hecker, M., Goertsches, R. H., Engelmann, R., Thiesen, H.-J. \& Guthke, R. (2009). Integrative modeling of transcriptional regulation in response to antirheumatic therapy. BMC bioinformatics 10, 262.

Hunter, D. J. (2005). Gene-environment interactions in human diseases. Nature reviews. Genetics 6(4), 287-98.

Hwang, W., Cho, Y.-R., Zhang, A. \& Ramanathan, M. (2006). Bridging centrality: identifying bridging nodes in scale-free networks. Proceedings of the 12th ACM SIGKDD international conference on Knowledge discovery and data mining , 20-23.

Iasevoli, F., Tomasetti, C., F. Buonaguro, E. \& de Bartolomeis, A. (2014). The glutamatergic aspects of schizophrenia molecular pathophysiology: Role of the postsynaptic density, and implications for treatment. Current Neuropharmacology 12(3), 219-238.

Ideker, T. \& Krogan, N. J. (2012). Differential network biology. Molecular systems biology 8(565), 565 . 
Irizarry, R. A., Hobbs, B., Collin, F., Beazer-Barclay, Y. D., Antonellis, K. J., Scherf, U. \& SPEEd, T. P. (2003). Exploration, normalization, and summaries of high density oligonucleotide array probe level data. Biostatistics (Oxford, England) 4(2), 249-64.

JiA, P., Sun, J., Guo, A. Y. \& Zhao, Z. (2010). Szgr: a comprehensive schizophrenia gene resource. Molecular psychiatry 15(5), 453-62.

Kaimal, V., Sardana, D., Bardes, E. E., Gudivada, R. C., Chen, J., Jegga, A. G., Disease, P. \& Genes, D. C. (2011). Disease gene identification. Gene 700, 241-259.

Keller, A., Backes, C., Gerasch, A., Kaufmann, M., Kohlbacher, O., Meese, E. \& Lenhof, H.P. (2009). A novel algorithm for detecting differentially regulated paths based on gene set enrichment analysis. Bioinformatics (Oxford, England) 25(21), 2787-94.

Kendall, M. G. \& Sмith, B. B. (1939). The problem of \$m\$ rankings.

Kido, M., Nakamura, Y., Nemoto, K., Takahashi, T., Alemsic, B., Furuichi, A., Nakamura, Y., Ikeda, M., Noguchi, K., Kaibuchi, K., Iwata, N., Ozaki, N. \& Suzuki, M. (2014). The polymorphism of ywhae, a gene encoding 14-3-3epsilon, and brain morphology in schizophrenia: A voxel-based morphometric study. PLOS ONE 9(8), 1-9.

Kim, S. \& Webster, M. J. (2010). The stanley neuropathology consortium integrative database: a novel, web-based tool for exploring neuropathological markers in psychiatric disorders and the biological processes associated with abnormalities of those markers. Neuropsychopharmacology 35(2), 473-482.

Kim, Y.-A., Wuchty, S. \& Przytycka, T. M. (2011). Identifying causal genes and dysregulated pathways in complex diseases. PLoS computational biology 7(3), e1001095.

Kohler, S., Bauer, S., Horn, D., Robinson, P. N. \& Ko, S. (2008). Walking the interactome for prioritization of candidate disease genes. Journal of Human Genetics 82(April), 949-958.

Kumari, S., Nie, J., Chen, H.-S., Ma, H., Stewart, R., Li, X., Lu, M.-Z., Taylor, W. M. \& Wei, H. (2012). Evaluation of gene association methods for coexpression network construction and biological knowledge discovery. PloS one 7(11), e50411.

Lage, K., Karlberg, E. O., Størling, Z. M., Olason, P. I., Pedersen, A. G., Rigina, O., Hinsby, A. M., Tümer, Z., Рociot, F., Tommerup, N., Moreau, Y. \& Brunak, S. (2007). A human phenome-interactome network of protein complexes implicated in genetic disorders. Nature biotechnology 25(3), 309-16.

Langfelder, P. \& Horvath, S. (2008). Wgcna: an r package for weighted correlation network analysis. BMC bioinformatics $\mathbf{9}, 559$.

Li, L., Kabesch, M., Bouzigon, E., Demenais, F., Farrall, M., Moffatt, M. F., Lin, X. \& Liang, L. (2013). Using eqtl weights to improve power for genome-wide association studies: a genetic study of childhood asthma. Frontiers in genetics 4(May), 103. 
Lima, L. D. A., Simoes, S. N., Hashimoto, R. F., Junior, D. C. M., Brentani, H. \& Mota, G. O. (2014). Network-based disease gene prioritization by hitting time analysis. In: 2014 IEEE International Conference on Bioinformatics and Bioengineering.

Macdonald, M. L., Ding, Y., Newman, J., Hemby, S., Penzes, P., Lewis, D. A., Yates, N. A. \& Sweet, R. A. (2014). Altered glutamate protein co-expression network topology linked to spine loss in the auditory cortex of schizophrenia. Biological Psychiatry, 1-10.

Managbanag, J. R., Witten, T. M., Bonchev, D., Fox, L. A., Tsuchiya, M., Kennedy, B. K. \& KaEBERLein, M. (2008). Shortest-path network analysis is a useful approach toward identifying genetic determinants of longevity. PloS one 3(11), e3802.

Maycox, P. R., Kelly, F., Taylor, A., Bates, S., Reid, J., Logendra, R., Barnes, M. R., Larminie, C., Jones, N., Lennon, M., Davies, C., Hagan, J. J., Scorer, C. A., Angelinetta, C., Akbar, M. T., Akbar, T., Hirsch, S., Mortimer, A. M., Barnes, T. R. E. \& de Belleroche, J. (2009). Analysis of gene expression in two large schizophrenia cohorts identifies multiple changes associated with nerve terminal function. Molecular psychiatry 14(12), 1083-94.

McCarthy, M. I., Abecasis, G. R., Cardon, L. R., Goldstein, D. B., Little, J., Ioannidis, J. P. a. \& Hirschrorn, J. N. (2008). Genome-wide association studies for complex traits: consensus, uncertainty and challenges. Nature reviews. Genetics 9(5), 356-69.

Michaelson, J. J., Loguercio, S. \& Beyer, A. (2009). Detection and interpretation of expression quantitative trait loci (eqtl). Methods (San Diego, Calif.) 48(3), 265-76.

Missiuro, P. V., Liu, K., Zou, L., Ross, B. C., Zhao, G., Liu, J. S. \& Ge, H. (2009). Information flow analysis of interactome networks. PLoS computational biology 5(4), e1000350.

Mitra, K., Carvunis, A.-R., Ramesh, S. K. \& Ideker, T. (2013). Integrative approaches for finding modular structure in biological networks. Nature reviews. Genetics 14(10), 719-32.

Nica, A. C. \& Dermitzakis, E. T. (2013). Expression quantitative trait loci: present and future. Philosophical transactions of the Royal Society of London. Series B, Biological sciences 368(1620), 20120362.

PaAtero, I. \& Elenius, K. (2008). Erbb4 and its isoforms: patentable drug targets? Recent patents on DNA E gene sequences 2(1), 27-33.

Pandey, G. N., Rizavi, H. S., Tripathi, M. \& Ren, X. (2015). Region-specific dysregulation of glycogen synthase kinase- $3 \beta$ and $\beta$-catenin in the postmortem brains of subjects with bipolar disorder and schizophrenia. Bipolar Disorders 17(2), 160-171.

Pavlopoulos, G. A., Secrier, M., Moschopoulos, C. N., Soldatos, T. G., Kossida, S., Aerts, J., SchNEIDER, R. \& BAGos, P. G. (2011). Using graph theory to analyze biological networks. BioData mining $\mathbf{4}(1), 10$.

PrzulJ, N., Wigle, D. A. \& Jurisica, I. (2004). Functional topology in a network of protein interactions. Bioinformatics (Oxford, England) 20(3), 340-8. 
Ritchie, M. D., Holzinger, E. R., Li, R., Pendergrass, S. A. \& Kim, D. (2015). Methods of integrating data to uncover genotype-phenotype interactions. Nature Reviews Genetics 16(2), 85-97.

Salter, M. W. \& Pitcher, G. M. (2011). Dysregulated src upregulation of nmda receptor activity: a common link in chronic pain and schizophrenia. The FEBS journal 279, 2-11.

Samsom, J. N. \& Wong, A. H. C. (2015). Schizophrenia and depression co-morbidity: What we have learned from animal models. Frontiers in Psychiatry 6(February), 1-24.

Schadt, E. E. (2009). Molecular networks as sensors and drivers of common human diseases. Nature 461(7261), 218-23.

Simões, S. N., Martins-JR, D. C., Brentani, H., Hashimoto, R. F. \& Fumio, R. (2012). Shortest paths ranking methodology to identify alterations in ppi networks of complex diseases. In: $A C M-B C B$. Orlando, FL.

Sinclair, D., Webster, M. J., Fullerton, J. M. \& Shannon Weickert, C. (2012). Glucocorticoid receptor mrna and protein isoform alterations in the orbitofrontal cortex in schizophrenia and bipolar disorder.

Solovieff, N., Cotsapas, C., Lee, P. H., Purcell, S. M. \& Smoller, J. W. (2013). Pleiotropy in complex traits: challenges and strategies. Nature reviews. Genetics 14(7), 483-95.

Stuart, J. M., Segal, E., Koller, D. \& Kim, S. K. (2003). A gene-coexpression network for global discovery of conserved genetic modules. Science (New York, N.Y.) 302(5643), 249-55.

Sullivan, P. F. P. P. F., Kendler, K. S. \& Neale, M. C. (2003). Schizophrenia as a complex trait: evidence from a meta-analysis of twin studies. Archives of general psychiatry 60(12), 1187-92.

Sun, J., Jia, P., Fanous, A. H., van den Oord, E., Chen, X., Riley, B. P., Amdur, R. L., Kendler, K. S. \& Zнао, Z. (2010). Schizophrenia gene networks and pathways and their applications for novel candidate gene selection. PloS one 5(6), e11351.

Suthram, S., Beyer, A., Karp, R. M., Eldar, Y. \& Ideker, T. (2008). eqed: an efficient method for interpreting eqtl associations using protein networks. Molecular systems biology 4(162), 162.

Swarnkar, T., Simoes, S. N., Martins, D. C., Anurak, A., Brentani, H., Hashimoto, R. F. \& MiTRA, P. (2014). Multiview clustering on ppi network for gene selection and enrichment from microarray data. In: 2014 IEEE International Conference on Bioinformatics and Bioengineering.

Tong, H., Faloutsos, C. \& Pan, J.-Y. (2007). Random walk with restart: fast solutions and applications. Knowledge and Information Systems 14(3), 327-346.

Ulitsky, I. \& Karp, R. (2008). Detecting disease-specific dysregulated pathways via analysis of clinical expression profiles. In: Research in Computational Molecular Biology, vol. 4955. Springer Berlin / Heidelberg, pp. 347-359. 
Vanunu, O., Magger, O., Ruppin, E., Shlomi, T. \& Sharan, R. (2010). Associating genes and protein complexes with disease via network propagation. PLoS computational biology 6(1), e1000641.

Vanunu, O. \& Sharan, R. (2008). A propagation-based algorithm for inferring gene-disease assocations. German Conference on Bioinformatics .

VêNcio, R. Z. N. \& KoIDE, T. (2005). Htself: Self-self based statistical test for low replication microarray studies. DNA Research 12(3), 211-214.

Vidal, M., Cusick, M. E. \& BarabÁsi, A.-L. (2011). Interactome networks and human disease. Cell 144(6), 986-98.

Wang, K., Li, M. \& Hakonarson, H. (2010). Analysing biological pathways in genome-wide association studies. Nature reviews. Genetics 11(12), 843-54.

White, S. \& Sмүтн, P. (2003). Algorithms for estimating relative importance in networks. In: Proceedings of the ninth ACM SIGKDD international conference on Knowledge discovery and data mining - KDD '03. New York, New York, USA: ACM Press.

Wu, X., Jiang, R., Zhang, M. Q. \& Li, S. (2008). Network-based global inference of human disease genes. Molecular systems biology 4(189), 189.

Xia, K., Shabalin, A. A., Huang, S., Madar, V., Zhou, Y.-H., Wang, W., Zou, F., Sun, W., Sullivan, P. F. \& Wright, F. A. (2012). seeqtl: a searchable database for human eqtls. Bioinformatics (Oxford, England) 28(3), 451-2. 